Supplement of Nat. Hazards Earth Syst. Sci., 19, 2465-2475, 2019

https://doi.org/10.5194/nhess-19-2465-2019-supplement

(C) Author(s) 2019. This work is distributed under

the Creative Commons Attribution 4.0 License.

(c) (1)

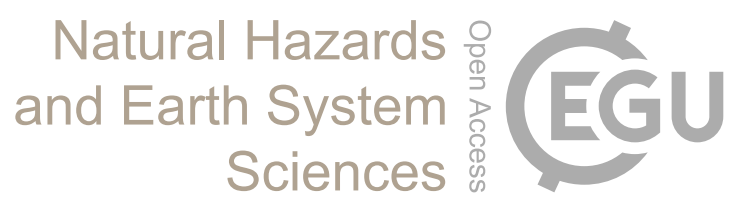

Supplement of

\title{
A global comparison of community-based responses to natural hazards
}

Barbara Paterson and Anthony Charles

Correspondence to: Barbara Paterson (barbara@paterson.alt.na)

The copyright of individual parts of the supplement might differ from the CC BY 4.0 License. 
The following table lists all articles from which information was extracted. The table is organized by World Region, Hazard Type and Response Type. Articles are represented by a unique identifier (ID).

The list below the table provides the bibliographic information for each article. 


\begin{tabular}{|c|c|c|c|}
\hline World Region & Hazard Type & Response Type & REF ID \\
\hline Africa & Climate & community fabric & 1555 \\
\hline Africa & Climate & community fabric & 48 \\
\hline Africa & Climate & community fabric & 543 \\
\hline Africa & Climate & food \& shelter & 48 \\
\hline Africa & Climate & food \& shelter & 543 \\
\hline Africa & Climate & knowledge \& learning & 1555 \\
\hline Africa & Climate & knowledge \& learning & 48 \\
\hline Africa & Climate & livelihood adaptations & 1555 \\
\hline Africa & Climate & livelihood adaptations & 2694 \\
\hline Africa & Climate & livelihood adaptations & 48 \\
\hline Africa & Climate & mobility & 78 \\
\hline Africa & Climate & mobility & 35 \\
\hline Africa & Climate & mobility & 60 \\
\hline Africa & Climate & money/economic & 2694 \\
\hline Africa & Climate & money/economic & 48 \\
\hline Africa & Earth & community fabric & 606 \\
\hline Africa & Earth & green protection & 606 \\
\hline Africa & Water & food \& shelter & 2561 \\
\hline Africa & Water & hard protection & 244 \\
\hline Africa & Water & hard protection & 2561 \\
\hline Africa & Water & info \& data & 244 \\
\hline Africa & Water & knowledge \& learning & 2561 \\
\hline Africa & Water & livelihood adaptations & 244 \\
\hline Africa & Water & livelihood adaptations & 2694 \\
\hline Africa & Water & money/economic & 2561 \\
\hline Africa & Water & money/economic & 2694 \\
\hline Africa & Water & search \& rescue & 244 \\
\hline Africa & Weather & community fabric & 1555 \\
\hline Africa & Weather & knowledge \& learning & 1555 \\
\hline Africa & Weather & livelihood adaptations & 1555 \\
\hline Africa & Weather & mobility & 78 \\
\hline Asia & Climate & community fabric & 1463 \\
\hline Asia & Climate & community fabric & 2414 \\
\hline Asia & Climate & community fabric & 813 \\
\hline Asia & Climate & food \& shelter & 596 \\
\hline Asia & Climate & food \& shelter & 1463 \\
\hline Asia & Climate & food \& shelter & 2414 \\
\hline Asia & Climate & governance & 596 \\
\hline Asia & Climate & info \& data & 2414 \\
\hline Asia & Climate & knowledge \& learning & 1501 \\
\hline Asia & Climate & knowledge \& learning & 2414 \\
\hline Asia & Climate & livelihood adaptations & 1463 \\
\hline Asia & Climate & livelihood adaptations & 530 \\
\hline Asia & Climate & livelihood adaptations & 2414 \\
\hline Asia & Climate & mobility & 596 \\
\hline Asia & Climate & mobility & 1463 \\
\hline Asia & Climate & mobility & 180 \\
\hline Asia & Climate & money/economic & 596 \\
\hline Asia & Climate & money/economic & 1463 \\
\hline Asia & Climate & money/economic & 389 \\
\hline Asia & Climate & money/economic & 2414 \\
\hline Asia & Climate & money/economic & 813 \\
\hline
\end{tabular}




\begin{tabular}{|c|c|c|c|}
\hline World Region & Hazard Type & Response Type & REF ID \\
\hline Asia & Climate & protect belongings & 2414 \\
\hline Asia & Earth & community fabric & 2121 \\
\hline Asia & Earth & community fabric & 2607 \\
\hline Asia & Earth & community fabric & 562 \\
\hline Asia & Earth & community fabric & 1740 \\
\hline Asia & Earth & community fabric & 527 \\
\hline Asia & Earth & community fabric & 3151 \\
\hline Asia & Earth & community fabric & 451 \\
\hline Asia & Earth & community fabric & 2746 \\
\hline Asia & Earth & community fabric & 1315 \\
\hline Asia & Earth & community fabric & 2321 \\
\hline Asia & Earth & community fabric & 1727 \\
\hline Asia & Earth & community fabric & 345 \\
\hline Asia & Earth & food \& shelter & 1684 \\
\hline Asia & Earth & food \& shelter & 2525 \\
\hline Asia & Earth & food \& shelter & 613 \\
\hline Asia & Earth & food \& shelter & 527 \\
\hline Asia & Earth & food \& shelter & 1698 \\
\hline Asia & Earth & food \& shelter & 613 \\
\hline Asia & Earth & food \& shelter & 2321 \\
\hline Asia & Earth & governance & 226 \\
\hline Asia & Earth & governance & 2332 \\
\hline Asia & Earth & governance & 2334 \\
\hline Asia & Earth & governance & 2607 \\
\hline Asia & Earth & governance & 288 \\
\hline Asia & Earth & governance & 189 \\
\hline Asia & Earth & governance & 2567 \\
\hline Asia & Earth & governance & 451 \\
\hline Asia & Earth & governance & 1520 \\
\hline Asia & Earth & governance & 517 \\
\hline Asia & Earth & governance & 1315 \\
\hline Asia & Earth & governance & 2321 \\
\hline Asia & Earth & governance & 2656 \\
\hline Asia & Earth & green protection & 451 \\
\hline Asia & Earth & green protection & 1698 \\
\hline Asia & Earth & green protection & 1315 \\
\hline Asia & Earth & green protection & 1683 \\
\hline Asia & Earth & green protection & 2622 \\
\hline Asia & Earth & hard protection & 3151 \\
\hline Asia & Earth & hard protection & 451 \\
\hline Asia & Earth & hard protection & 2622 \\
\hline Asia & Earth & info \& data & 451 \\
\hline Asia & Earth & info \& data & 1315 \\
\hline Asia & Earth & info \& data & 2321 \\
\hline Asia & Earth & info \& data & 2622 \\
\hline Asia & Earth & knowledge \& learning & 2118 \\
\hline Asia & Earth & knowledge \& learning & 527 \\
\hline Asia & Earth & knowledge \& learning & 354 \\
\hline Asia & Earth & knowledge \& learning & 2118 \\
\hline Asia & Earth & knowledge \& learning & 354 \\
\hline Asia & Earth & knowledge \& learning & 2456 \\
\hline Asia & Earth & knowledge \& learning & 2622 \\
\hline
\end{tabular}




\begin{tabular}{|c|c|c|c|}
\hline World Region & Hazard Type & Response Type & REF ID \\
\hline Asia & Earth & knowledge \& learning & 3160 \\
\hline Asia & Earth & livelihood adaptations & 451 \\
\hline Asia & Earth & mobility & 613 \\
\hline Asia & Earth & mobility & 527 \\
\hline Asia & Earth & mobility & 3151 \\
\hline Asia & Earth & mobility & 356 \\
\hline Asia & Earth & mobility & 451 \\
\hline Asia & Earth & mobility & 2481 \\
\hline Asia & Earth & mobility & 2755 \\
\hline Asia & Earth & mobility & 356 \\
\hline Asia & Earth & mobility & 613 \\
\hline Asia & Earth & mobility & 2622 \\
\hline Asia & Earth & mobility & 2639 \\
\hline Asia & Earth & mobility & 1727 \\
\hline Asia & Earth & mobility & 390 \\
\hline Asia & Earth & money/economic & 1520 \\
\hline Asia & Earth & money/economic & 1698 \\
\hline Asia & Earth & money/economic & 2321 \\
\hline Asia & Earth & other social & 2332 \\
\hline Asia & Earth & planning & 288 \\
\hline Asia & Earth & planning & 613 \\
\hline Asia & Earth & planning & 1315 \\
\hline Asia & Earth & planning & 2622 \\
\hline Asia & Earth & planning & 2656 \\
\hline Asia & Earth & planning & 3160 \\
\hline Asia & Earth & psychological & 2332 \\
\hline Asia & Earth & psychological & 562 \\
\hline Asia & Earth & psychological & 2755 \\
\hline Asia & Water & community fabric & 1740 \\
\hline Asia & Water & community fabric & 179 \\
\hline Asia & Water & community fabric & 2604 \\
\hline Asia & Water & community fabric & 2414 \\
\hline Asia & Water & community fabric & 1015 \\
\hline Asia & Water & community fabric & 562 \\
\hline Asia & Water & community fabric & 1307 \\
\hline Asia & Water & community fabric & 1740 \\
\hline Asia & Water & community fabric & 1999 \\
\hline Asia & Water & community fabric & 2414 \\
\hline Asia & Water & community fabric & 487 \\
\hline Asia & Water & community fabric & 2414 \\
\hline Asia & Water & food \& shelter & 2414 \\
\hline Asia & Water & food \& shelter & 1015 \\
\hline Asia & Water & food \& shelter & 1791 \\
\hline Asia & Water & food \& shelter & 2427 \\
\hline Asia & Water & food \& shelter & 2599 \\
\hline Asia & Water & food \& shelter & 503 \\
\hline Asia & Water & food \& shelter & 836 \\
\hline Asia & Water & food \& shelter & 1999 \\
\hline Asia & Water & food \& shelter & 2414 \\
\hline Asia & Water & food \& shelter & 487 \\
\hline Asia & Water & food \& shelter & 1791 \\
\hline Asia & Water & food \& shelter & 2414 \\
\hline
\end{tabular}




\begin{tabular}{|c|c|c|c|}
\hline World Region & Hazard Type & Response Type & REF ID \\
\hline Asia & Water & governance & 1740 \\
\hline Asia & Water & governance & 179 \\
\hline Asia & Water & governance & 1307 \\
\hline Asia & Water & governance & 1999 \\
\hline Asia & Water & governance & 487 \\
\hline Asia & Water & governance & 557 \\
\hline Asia & Water & green protection & 179 \\
\hline Asia & Water & hard protection & 179 \\
\hline Asia & Water & hard protection & 1023 \\
\hline Asia & Water & hard protection & 1482 \\
\hline Asia & Water & hard protection & 2427 \\
\hline Asia & Water & hard protection & 2599 \\
\hline Asia & Water & hard protection & 836 \\
\hline Asia & Water & hard protection & 487 \\
\hline Asia & Water & hard protection & 557 \\
\hline Asia & Water & info \& data & 2414 \\
\hline Asia & Water & info \& data & 1015 \\
\hline Asia & Water & info \& data & 2427 \\
\hline Asia & Water & info \& data & 1307 \\
\hline Asia & Water & info \& data & 2414 \\
\hline Asia & Water & info \& data & 557 \\
\hline Asia & Water & knowledge \& learning & 179 \\
\hline Asia & Water & knowledge \& learning & 2414 \\
\hline Asia & Water & knowledge \& learning & 1791 \\
\hline Asia & Water & knowledge \& learning & 354 \\
\hline Asia & Water & knowledge \& learning & 557 \\
\hline Asia & Water & knowledge \& learning & 1791 \\
\hline Asia & Water & knowledge \& learning & 1501 \\
\hline Asia & Water & livelihood adaptations & 2414 \\
\hline Asia & Water & livelihood adaptations & 1015 \\
\hline Asia & Water & livelihood adaptations & 503 \\
\hline Asia & Water & mobility & 179 \\
\hline Asia & Water & mobility & 2604 \\
\hline Asia & Water & mobility & 166 \\
\hline Asia & Water & mobility & 2486 \\
\hline Asia & Water & mobility & 1015 \\
\hline Asia & Water & mobility & 136 \\
\hline Asia & Water & mobility & 1791 \\
\hline Asia & Water & mobility & 2427 \\
\hline Asia & Water & mobility & 2486 \\
\hline Asia & Water & mobility & 356 \\
\hline Asia & Water & mobility & 412 \\
\hline Asia & Water & mobility & 503 \\
\hline Asia & Water & mobility & 629 \\
\hline Asia & Water & mobility & 1307 \\
\hline Asia & Water & mobility & 487 \\
\hline Asia & Water & mobility & 1791 \\
\hline Asia & Water & mobility & 331 \\
\hline Asia & Water & money/economic & 813 \\
\hline Asia & Water & money/economic & 2486 \\
\hline Asia & Water & money/economic & 513 \\
\hline Asia & Water & money/economic & 2414 \\
\hline
\end{tabular}




\begin{tabular}{|c|c|c|c|}
\hline World Region & Hazard Type & Response Type & REF ID \\
\hline Asia & Water & money/economic & 2427 \\
\hline Asia & Water & money/economic & 389 \\
\hline Asia & Water & money/economic & 503 \\
\hline Asia & Water & money/economic & 1999 \\
\hline Asia & Water & money/economic & 487 \\
\hline Asia & Water & money/economic & 813 \\
\hline Asia & Water & money/economic & 513 \\
\hline Asia & Water & planning & 1740 \\
\hline Asia & Water & planning & 1023 \\
\hline Asia & Water & planning & 2427 \\
\hline Asia & Water & planning & 2599 \\
\hline Asia & Water & planning & 836 \\
\hline Asia & Water & planning & 557 \\
\hline Asia & Water & protect belongings & 2414 \\
\hline Asia & Water & protect belongings & 1015 \\
\hline Asia & Water & protect belongings & 1482 \\
\hline Asia & Water & protect belongings & 2599 \\
\hline Asia & Water & protect belongings & 836 \\
\hline Asia & Water & psychological & 562 \\
\hline Asia & Water & psychological & 487 \\
\hline Asia & Water & search \& rescue & 1307 \\
\hline Asia & Weather & community fabric & 1740 \\
\hline Asia & Weather & community fabric & 317 \\
\hline Asia & Weather & community fabric & 882 \\
\hline Asia & Weather & community fabric & 1307 \\
\hline Asia & Weather & community fabric & 2414 \\
\hline Asia & Weather & food \& shelter & 1628 \\
\hline Asia & Weather & food \& shelter & 1791 \\
\hline Asia & Weather & food \& shelter & 2486 \\
\hline Asia & Weather & food \& shelter & 2414 \\
\hline Asia & Weather & governance & 1740 \\
\hline Asia & Weather & governance & 147 \\
\hline Asia & Weather & governance & 1626 \\
\hline Asia & Weather & governance & 1628 \\
\hline Asia & Weather & governance & 524 \\
\hline Asia & Weather & governance & 882 \\
\hline Asia & Weather & info \& data & 1628 \\
\hline Asia & Weather & info \& data & 524 \\
\hline Asia & Weather & info \& data & 882 \\
\hline Asia & Weather & info $\&$ data & 2414 \\
\hline Asia & Weather & knowledge \& learning & 1791 \\
\hline Asia & Weather & knowledge \& learning & 2414 \\
\hline Asia & Weather & livelihood adaptations & 2414 \\
\hline Asia & Weather & mobility & 412 \\
\hline Asia & Weather & mobility & 136 \\
\hline Asia & Weather & mobility & 1791 \\
\hline Asia & Weather & mobility & 2486 \\
\hline Asia & Weather & mobility & 331 \\
\hline Asia & Weather & mobility & 629 \\
\hline Asia & Weather & mobility & 846 \\
\hline Asia & Weather & mobility & 2434 \\
\hline Asia & Weather & money/economic & 2486 \\
\hline
\end{tabular}




\begin{tabular}{|c|c|c|c|}
\hline World Region & Hazard Type & Response Type & REF ID \\
\hline Asia & Weather & money/economic & 389 \\
\hline Asia & Weather & money/economic & 513 \\
\hline Asia & Weather & money/economic & 882 \\
\hline Asia & Weather & money/economic & 2414 \\
\hline Asia & Weather & planning & 1740 \\
\hline Asia & Weather & protect belongings & 2414 \\
\hline Asia & Weather & search \& rescue & 1307 \\
\hline Europe & Climate & community fabric & 1061 \\
\hline Europe & Climate & food \& shelter & 1454 \\
\hline Europe & Climate & info \& data & 1454 \\
\hline Europe & Climate & knowledge \& learning & 1454 \\
\hline Europe & Climate & livelihood adaptations & 1454 \\
\hline Europe & Climate & money/economic & 1454 \\
\hline Europe & Earth & governance & 3159 \\
\hline Europe & Earth & green protection & 3159 \\
\hline Europe & Earth & hard protection & 3159 \\
\hline Europe & Earth & info \& data & 3159 \\
\hline Europe & Earth & knowledge \& learning & 154 \\
\hline Europe & Earth & mobility & 3159 \\
\hline Europe & Earth & mobility & 345 \\
\hline Europe & Earth & planning & 298 \\
\hline Europe & Earth & planning & 154 \\
\hline Europe & Water & community fabric & 349 \\
\hline Europe & Water & community fabric & 829 \\
\hline Europe & Water & community fabric & 1454 \\
\hline Europe & Water & community fabric & 3190 \\
\hline Europe & Water & community fabric & 57 \\
\hline Europe & Water & food \& shelter & 2480 \\
\hline Europe & Water & food \& shelter & 472 \\
\hline Europe & Water & food \& shelter & 1454 \\
\hline Europe & Water & governance & 174 \\
\hline Europe & Water & governance & 349 \\
\hline Europe & Water & governance & 472 \\
\hline Europe & Water & governance & 174 \\
\hline Europe & Water & governance & 3190 \\
\hline Europe & Water & governance & 329 \\
\hline Europe & Water & governance & 834 \\
\hline Europe & Water & green protection & 829 \\
\hline Europe & Water & hard protection & 174 \\
\hline Europe & Water & hard protection & 2480 \\
\hline Europe & Water & hard protection & 349 \\
\hline Europe & Water & hard protection & 829 \\
\hline Europe & Water & hard protection & 174 \\
\hline Europe & Water & hard protection & 834 \\
\hline Europe & Water & hard protection & 2666 \\
\hline Europe & Water & info \& data & 2480 \\
\hline Europe & Water & info \& data & 349 \\
\hline Europe & Water & info \& data & 829 \\
\hline Europe & Water & info \& data & 1454 \\
\hline Europe & Water & info \& data & 2134 \\
\hline Europe & Water & info \& data & 3190 \\
\hline Europe & Water & info \& data & 329 \\
\hline
\end{tabular}




\begin{tabular}{|c|c|c|c|}
\hline World Region & Hazard Type & Response Type & REF ID \\
\hline Europe & Water & knowledge \& learning & 2480 \\
\hline Europe & Water & knowledge \& learning & 829 \\
\hline Europe & Water & knowledge \& learning & 1454 \\
\hline Europe & Water & knowledge \& learning & 3190 \\
\hline Europe & Water & knowledge \& learning & 57 \\
\hline Europe & Water & livelihood adaptations & 1454 \\
\hline Europe & Water & mobility & 472 \\
\hline Europe & Water & mobility & 1454 \\
\hline Europe & Water & mobility & 329 \\
\hline Europe & Water & mobility & 43 \\
\hline Europe & Water & money/economic & 2480 \\
\hline Europe & Water & money/economic & 1454 \\
\hline Europe & Water & planning & 174 \\
\hline Europe & Water & planning & 1454 \\
\hline Europe & Water & planning & 174 \\
\hline Europe & Water & planning & 329 \\
\hline Europe & Water & planning & 43 \\
\hline Europe & Water & planning & 57 \\
\hline Europe & Water & protect belongings & 2258 \\
\hline Europe & Water & protect belongings & 2480 \\
\hline Europe & Weather & community fabric & 349 \\
\hline Europe & Weather & hard protection & 2666 \\
\hline Europe & Weather & hard protection & 349 \\
\hline Europe & Weather & info \& data & 349 \\
\hline Caribbean & Climate & community fabric & 2416 \\
\hline Caribbean & Climate & community fabric & 420 \\
\hline Caribbean & Climate & community fabric & 2416 \\
\hline Caribbean & Climate & food \& shelter & 2416 \\
\hline Caribbean & Climate & food \& shelter & 420 \\
\hline Caribbean & Climate & food \& shelter & 2416 \\
\hline Caribbean & Climate & livelihood adaptations & 2558 \\
\hline Caribbean & Climate & livelihood adaptations & 420 \\
\hline Caribbean & Climate & money/economic & 2416 \\
\hline Caribbean & Climate & money/economic & 420 \\
\hline Caribbean & Climate & money/economic & 2416 \\
\hline Caribbean & Climate & other social & 420 \\
\hline Caribbean & Climate & planning & 2416 \\
\hline Caribbean & Climate & protect belongings & 2416 \\
\hline Caribbean & Earth & community fabric & 2416 \\
\hline Caribbean & Earth & community fabric & 2489 \\
\hline Caribbean & Earth & community fabric & 2416 \\
\hline Caribbean & Earth & food \& shelter & 2416 \\
\hline Caribbean & Earth & governance & 345 \\
\hline Caribbean & Earth & governance & 2656 \\
\hline Caribbean & Earth & green protection & 2622 \\
\hline Caribbean & Earth & hard protection & 2651 \\
\hline Caribbean & Earth & hard protection & 2441 \\
\hline Caribbean & Earth & hard protection & 2622 \\
\hline Caribbean & Earth & hard protection & 2656 \\
\hline Caribbean & Earth & info \& data & 1771 \\
\hline Caribbean & Earth & info \& data & 2489 \\
\hline Caribbean & Earth & info \& data & 2622 \\
\hline
\end{tabular}




\begin{tabular}{|c|c|c|c|}
\hline World Region & Hazard Type & $\begin{array}{l}\text { Response Type } \\
\end{array}$ & REF ID \\
\hline Caribbean & Earth & knowledge \& learning & 2489 \\
\hline Caribbean & Earth & knowledge \& learning & 2656 \\
\hline Caribbean & Earth & mobility & 2441 \\
\hline Caribbean & Earth & mobility & 2489 \\
\hline Caribbean & Earth & mobility & 2622 \\
\hline Caribbean & Earth & mobility & 890 \\
\hline Caribbean & Earth & money/economic & 2416 \\
\hline Caribbean & Earth & money/economic & 2441 \\
\hline Caribbean & Earth & money/economic & 2416 \\
\hline Caribbean & Earth & planning & 2416 \\
\hline Caribbean & Earth & planning & 2622 \\
\hline Caribbean & Earth & planning & 2416 \\
\hline Caribbean & Water & community fabric & 345 \\
\hline Caribbean & Water & community fabric & 1573 \\
\hline Caribbean & Water & community fabric & 2416 \\
\hline Caribbean & Water & food \& shelter & 2416 \\
\hline Caribbean & Water & governance & 1029 \\
\hline Caribbean & Water & hard protection & 554 \\
\hline Caribbean & Water & hard protection & 1029 \\
\hline Caribbean & Water & hard protection & 1440 \\
\hline Caribbean & Water & hard protection & 2416 \\
\hline Caribbean & Water & hard protection & 90 \\
\hline Caribbean & Water & info \& data & 820 \\
\hline Caribbean & Water & info \& data & 1440 \\
\hline Caribbean & Water & info \& data & 1771 \\
\hline Caribbean & Water & knowledge \& learning & 1573 \\
\hline Caribbean & Water & knowledge \& learning & 190 \\
\hline Caribbean & Water & knowledge \& learning & 1440 \\
\hline Caribbean & Water & money/economic & 2416 \\
\hline Caribbean & Water & planning & 1029 \\
\hline Caribbean & Water & planning & 2416 \\
\hline Caribbean & Water & protect belongings & 554 \\
\hline Caribbean & Water & protect belongings & 2416 \\
\hline Caribbean & Water & psychological & 1573 \\
\hline Caribbean & Weather & community fabric & 1475 \\
\hline Caribbean & Weather & community fabric & 939 \\
\hline Caribbean & Weather & food \& shelter & 1623 \\
\hline Caribbean & Weather & food \& shelter & 2416 \\
\hline Caribbean & Weather & food \& shelter & 939 \\
\hline Caribbean & Weather & governance & 495 \\
\hline Caribbean & Weather & green protection & 1623 \\
\hline Caribbean & Weather & hard protection & 2441 \\
\hline Caribbean & Weather & hard protection & 1623 \\
\hline Caribbean & Weather & hard protection & 2416 \\
\hline Caribbean & Weather & knowledge \& learning & 1623 \\
\hline Caribbean & Weather & livelihood adaptations & 1475 \\
\hline Caribbean & Weather & livelihood adaptations & 2805 \\
\hline Caribbean & Weather & mobility & 2441 \\
\hline Caribbean & Weather & money/economic & 2441 \\
\hline Caribbean & Weather & money/economic & 1475 \\
\hline Caribbean & Weather & money/economic & 2441 \\
\hline Caribbean & Weather & money/economic & 1623 \\
\hline
\end{tabular}




\begin{tabular}{|c|c|c|c|}
\hline World Region & Hazard Type & Response Type & REF ID \\
\hline Caribbean & Weather & money/economic & 2416 \\
\hline Caribbean & Weather & money/economic & 2805 \\
\hline Caribbean & Weather & planning & 2416 \\
\hline Caribbean & Weather & protect belongings & 2416 \\
\hline Caribbean & Weather & protect belongings & 2805 \\
\hline Northern America & Climate & community fabric & 408 \\
\hline Northern America & Climate & knowledge \& learning & 1036 \\
\hline Northern America & Climate & knowledge \& learning & 603 \\
\hline Northern America & Climate & mobility & 181 \\
\hline Northern America & Climate & mobility & 153 \\
\hline Northern America & Climate & mobility & 196 \\
\hline Northern America & Earth & community fabric & 345 \\
\hline Northern America & Earth & mobility & 345 \\
\hline Northern America & Water & community fabric & 408 \\
\hline Northern America & Water & community fabric & 499 \\
\hline Northern America & Water & community fabric & 744 \\
\hline Northern America & Water & community fabric & 565 \\
\hline Northern America & Water & community fabric & 408 \\
\hline Northern America & Water & food \& shelter & 744 \\
\hline Northern America & Water & governance & 2673 \\
\hline Northern America & Water & governance & 1990 \\
\hline Northern America & Water & governance & 2051 \\
\hline Northern America & Water & governance & 496 \\
\hline Northern America & Water & governance & 744 \\
\hline Northern America & Water & governance & 1008 \\
\hline Northern America & Water & hard protection & 858 \\
\hline Northern America & Water & hard protection & 1993 \\
\hline Northern America & Water & hard protection & 2051 \\
\hline Northern America & Water & hard protection & 1008 \\
\hline Northern America & Water & info $\&$ data & 496 \\
\hline Northern America & Water & info \& data & 744 \\
\hline Northern America & Water & mobility & 121 \\
\hline Northern America & Water & mobility & 858 \\
\hline Northern America & Water & mobility & 1008 \\
\hline Northern America & Water & money/economic & 1008 \\
\hline Northern America & Water & other social & 744 \\
\hline Northern America & Water & planning & 499 \\
\hline Northern America & Water & planning & 744 \\
\hline Northern America & Water & planning & 1008 \\
\hline Northern America & Water & protect belongings & 744 \\
\hline Northern America & Weather & community fabric & 2287 \\
\hline Northern America & Weather & community fabric & 995 \\
\hline Northern America & Weather & community fabric & 2516 \\
\hline Northern America & Weather & community fabric & 633 \\
\hline Northern America & Weather & food \& shelter & 995 \\
\hline Northern America & Weather & food \& shelter & 2516 \\
\hline Northern America & Weather & food \& shelter & 633 \\
\hline Northern America & Weather & governance & 1990 \\
\hline Northern America & Weather & governance & 2612 \\
\hline Northern America & Weather & governance & 496 \\
\hline Northern America & Weather & governance & 1646 \\
\hline Northern America & Weather & governance & 2147 \\
\hline
\end{tabular}




\begin{tabular}{|c|c|c|c|}
\hline World Region & Hazard Type & Response Type & REF ID \\
\hline Northern America & Weather & green protection & 2023 \\
\hline Northern America & Weather & hard protection & 1657 \\
\hline Northern America & Weather & hard protection & 1993 \\
\hline Northern America & Weather & hard protection & 2110 \\
\hline Northern America & Weather & hard protection & 1646 \\
\hline Northern America & Weather & hard protection & 2667 \\
\hline Northern America & Weather & info \& data & 2042 \\
\hline Northern America & Weather & info \& data & 995 \\
\hline Northern America & Weather & knowledge \& learning & 633 \\
\hline Northern America & Weather & mobility & 159 \\
\hline Northern America & Weather & mobility & 1829 \\
\hline Northern America & Weather & mobility & 196 \\
\hline Northern America & Weather & mobility & 2042 \\
\hline Northern America & Weather & mobility & 2137 \\
\hline Northern America & Weather & mobility & 496 \\
\hline Northern America & Weather & mobility & 995 \\
\hline Northern America & Weather & mobility & 1008 \\
\hline Northern America & Weather & mobility & 1646 \\
\hline Northern America & Weather & mobility & 1654 \\
\hline Northern America & Weather & mobility & 1953 \\
\hline Northern America & Weather & mobility & 2003 \\
\hline Northern America & Weather & mobility & 633 \\
\hline Northern America & Weather & money/economic & 2036 \\
\hline Northern America & Weather & money/economic & 995 \\
\hline Northern America & Weather & money/economic & 1008 \\
\hline Northern America & Weather & other social & 2612 \\
\hline Northern America & Weather & other social & 995 \\
\hline Northern America & Weather & planning & 2042 \\
\hline Northern America & Weather & planning & 693 \\
\hline Northern America & Weather & planning & 1646 \\
\hline Northern America & Weather & psychological & 1997 \\
\hline Northern America & Weather & psychological & 2612 \\
\hline Northern America & Weather & psychological & 2516 \\
\hline Northern America & Weather & psychological & 633 \\
\hline Oceania & Climate & community fabric & 1468 \\
\hline Oceania & Climate & food \& shelter & 1468 \\
\hline Oceania & Climate & food \& shelter & 2247 \\
\hline Oceania & Climate & governance & 1468 \\
\hline Oceania & Climate & governance & 658 \\
\hline Oceania & Climate & livelihood adaptations & 1468 \\
\hline Oceania & Climate & mobility & 2247 \\
\hline Oceania & Climate & mobility & 153 \\
\hline Oceania & Climate & mobility & 2500 \\
\hline Oceania & Climate & mobility & 2557 \\
\hline Oceania & Climate & planning & 2557 \\
\hline Oceania & Earth & community fabric & 899 \\
\hline Oceania & Earth & community fabric & 1333 \\
\hline Oceania & Earth & community fabric & 592 \\
\hline Oceania & Earth & community fabric & 345 \\
\hline Oceania & Earth & food $\&$ shelter & 899 \\
\hline Oceania & Earth & governance & 592 \\
\hline Oceania & Earth & info \& data & 592 \\
\hline
\end{tabular}




\begin{tabular}{|c|c|c|c|}
\hline World Region & Hazard Type & Response Type & REF ID \\
\hline Oceania & Earth & mobility & 899 \\
\hline Oceania & Earth & mobility & 1333 \\
\hline Oceania & Earth & other social & 592 \\
\hline Oceania & Earth & psychological & 899 \\
\hline Oceania & Earth & search \& rescue & 592 \\
\hline Oceania & Water & community fabric & 2495 \\
\hline Oceania & Water & governance & 1800 \\
\hline Oceania & Water & green protection & 1800 \\
\hline Oceania & Water & hard protection & 1800 \\
\hline Oceania & Water & hard protection & 3141 \\
\hline Oceania & Water & mobility & 2495 \\
\hline Oceania & Water & money/economic & 3141 \\
\hline Oceania & Water & psychological & 1800 \\
\hline Oceania & Weather & community fabric & 1468 \\
\hline Oceania & Weather & community fabric & 1800 \\
\hline Oceania & Weather & community fabric & 345 \\
\hline Oceania & Weather & food \& shelter & 1468 \\
\hline Oceania & Weather & food \& shelter & 1649 \\
\hline Oceania & Weather & food \& shelter & 2247 \\
\hline Oceania & Weather & governance & 1468 \\
\hline Oceania & Weather & governance & 345 \\
\hline Oceania & Weather & green protection & 1800 \\
\hline Oceania & Weather & hard protection & 1468 \\
\hline Oceania & Weather & info \& data & 1649 \\
\hline Oceania & Weather & knowledge \& learning & 1649 \\
\hline Oceania & Weather & knowledge \& learning & 1800 \\
\hline Oceania & Weather & livelihood adaptations & 1468 \\
\hline Oceania & Weather & livelihood adaptations & 345 \\
\hline Oceania & Weather & mobility & 2247 \\
\hline Oceania & Weather & money/economic & 345 \\
\hline
\end{tabular}




\begin{tabular}{|c|c|c|c|}
\hline World Region & Hazard Type & Response Type & REF ID \\
\hline Africa & Climate & community fabric & 1555 \\
\hline Africa & Climate & community fabric & 48 \\
\hline Africa & Climate & community fabric & 543 \\
\hline Africa & Climate & food \& shelter & 48 \\
\hline Africa & Climate & food \& shelter & 543 \\
\hline Africa & Climate & knowledge \& learning & 1555 \\
\hline Africa & Climate & knowledge \& learning & 48 \\
\hline Africa & Climate & livelihood adaptations & 1555 \\
\hline Africa & Climate & livelihood adaptations & 2694 \\
\hline Africa & Climate & livelihood adaptations & 48 \\
\hline Africa & Climate & mobility & 78 \\
\hline Africa & Climate & mobility & 35 \\
\hline Africa & Climate & mobility & 60 \\
\hline Africa & Climate & money/economic & 2694 \\
\hline Africa & Climate & money/economic & 48 \\
\hline Africa & Earth & community fabric & 606 \\
\hline Africa & Earth & green protection & 606 \\
\hline Africa & Water & food \& shelter & 2561 \\
\hline Africa & Water & hard protection & 244 \\
\hline Africa & Water & hard protection & 2561 \\
\hline Africa & Water & info \& data & 244 \\
\hline Africa & Water & knowledge \& learning & 2561 \\
\hline Africa & Water & livelihood adaptations & 244 \\
\hline Africa & Water & livelihood adaptations & 2694 \\
\hline Africa & Water & money/economic & 2561 \\
\hline Africa & Water & money/economic & 2694 \\
\hline Africa & Water & search \& rescue & 244 \\
\hline Africa & Weather & community fabric & 1555 \\
\hline Africa & Weather & knowledge \& learning & 1555 \\
\hline Africa & Weather & livelihood adaptations & 1555 \\
\hline Africa & Weather & mobility & 78 \\
\hline Asia & Climate & community fabric & 1463 \\
\hline Asia & Climate & community fabric & 2414 \\
\hline Asia & Climate & community fabric & 813 \\
\hline Asia & Climate & food \& shelter & 596 \\
\hline Asia & Climate & food \& shelter & 1463 \\
\hline Asia & Climate & food \& shelter & 2414 \\
\hline Asia & Climate & governance & 596 \\
\hline Asia & Climate & info \& data & 2414 \\
\hline Asia & Climate & knowledge \& learning & 1501 \\
\hline Asia & Climate & knowledge \& learning & 2414 \\
\hline Asia & Climate & livelihood adaptations & 1463 \\
\hline Asia & Climate & livelihood adaptations & 530 \\
\hline Asia & Climate & livelihood adaptations & 2414 \\
\hline Asia & Climate & mobility & 596 \\
\hline Asia & Climate & mobility & 1463 \\
\hline Asia & Climate & mobility & 180 \\
\hline Asia & Climate & money/economic & 596 \\
\hline Asia & Climate & money/economic & 1463 \\
\hline Asia & Climate & money/economic & 389 \\
\hline Asia & Climate & money/economic & 2414 \\
\hline Asia & Climate & money/economic & 813 \\
\hline
\end{tabular}




\begin{tabular}{|c|c|c|c|}
\hline World Region & Hazard Type & Response Type & REF ID \\
\hline Asia & Climate & protect belongings & 2414 \\
\hline Asia & Earth & community fabric & 2121 \\
\hline Asia & Earth & community fabric & 2607 \\
\hline Asia & Earth & community fabric & 562 \\
\hline Asia & Earth & community fabric & 1740 \\
\hline Asia & Earth & community fabric & 527 \\
\hline Asia & Earth & community fabric & 3151 \\
\hline Asia & Earth & community fabric & 451 \\
\hline Asia & Earth & community fabric & 2746 \\
\hline Asia & Earth & community fabric & 1315 \\
\hline Asia & Earth & community fabric & 2321 \\
\hline Asia & Earth & community fabric & 1727 \\
\hline Asia & Earth & community fabric & 345 \\
\hline Asia & Earth & food \& shelter & 1684 \\
\hline Asia & Earth & food \& shelter & 2525 \\
\hline Asia & Earth & food \& shelter & 613 \\
\hline Asia & Earth & food \& shelter & 527 \\
\hline Asia & Earth & food \& shelter & 1698 \\
\hline Asia & Earth & food \& shelter & 613 \\
\hline Asia & Earth & food \& shelter & 2321 \\
\hline Asia & Earth & governance & 226 \\
\hline Asia & Earth & governance & 2332 \\
\hline Asia & Earth & governance & 2334 \\
\hline Asia & Earth & governance & 2607 \\
\hline Asia & Earth & governance & 288 \\
\hline Asia & Earth & governance & 189 \\
\hline Asia & Earth & governance & 2567 \\
\hline Asia & Earth & governance & 451 \\
\hline Asia & Earth & governance & 1520 \\
\hline Asia & Earth & governance & 517 \\
\hline Asia & Earth & governance & 1315 \\
\hline Asia & Earth & governance & 2321 \\
\hline Asia & Earth & governance & 2656 \\
\hline Asia & Earth & green protection & 451 \\
\hline Asia & Earth & green protection & 1698 \\
\hline Asia & Earth & green protection & 1315 \\
\hline Asia & Earth & green protection & 1683 \\
\hline Asia & Earth & green protection & 2622 \\
\hline Asia & Earth & hard protection & 3151 \\
\hline Asia & Earth & hard protection & 451 \\
\hline Asia & Earth & hard protection & 2622 \\
\hline Asia & Earth & info \& data & 451 \\
\hline Asia & Earth & info \& data & 1315 \\
\hline Asia & Earth & info \& data & 2321 \\
\hline Asia & Earth & info \& data & 2622 \\
\hline Asia & Earth & knowledge \& learning & 2118 \\
\hline Asia & Earth & knowledge \& learning & 527 \\
\hline Asia & Earth & knowledge \& learning & 354 \\
\hline Asia & Earth & knowledge \& learning & 2118 \\
\hline Asia & Earth & knowledge \& learning & 354 \\
\hline Asia & Earth & knowledge \& learning & 2456 \\
\hline Asia & Earth & knowledge \& learning & 2622 \\
\hline
\end{tabular}




\begin{tabular}{|c|c|c|c|}
\hline World Region & Hazard Type & Response Type & REF ID \\
\hline Asia & Earth & knowledge \& learning & 3160 \\
\hline Asia & Earth & livelihood adaptations & 451 \\
\hline Asia & Earth & mobility & 613 \\
\hline Asia & Earth & mobility & 527 \\
\hline Asia & Earth & mobility & 3151 \\
\hline Asia & Earth & mobility & 356 \\
\hline Asia & Earth & mobility & 451 \\
\hline Asia & Earth & mobility & 2481 \\
\hline Asia & Earth & mobility & 2755 \\
\hline Asia & Earth & mobility & 356 \\
\hline Asia & Earth & mobility & 613 \\
\hline Asia & Earth & mobility & 2622 \\
\hline Asia & Earth & mobility & 2639 \\
\hline Asia & Earth & mobility & 1727 \\
\hline Asia & Earth & mobility & 390 \\
\hline Asia & Earth & money/economic & 1520 \\
\hline Asia & Earth & money/economic & 1698 \\
\hline Asia & Earth & money/economic & 2321 \\
\hline Asia & Earth & other social & 2332 \\
\hline Asia & Earth & planning & 288 \\
\hline Asia & Earth & planning & 613 \\
\hline Asia & Earth & planning & 1315 \\
\hline Asia & Earth & planning & 2622 \\
\hline Asia & Earth & planning & 2656 \\
\hline Asia & Earth & planning & 3160 \\
\hline Asia & Earth & psychological & 2332 \\
\hline Asia & Earth & psychological & 562 \\
\hline Asia & Earth & psychological & 2755 \\
\hline Asia & Water & community fabric & 1740 \\
\hline Asia & Water & community fabric & 179 \\
\hline Asia & Water & community fabric & 2604 \\
\hline Asia & Water & community fabric & 2414 \\
\hline Asia & Water & community fabric & 1015 \\
\hline Asia & Water & community fabric & 562 \\
\hline Asia & Water & community fabric & 1307 \\
\hline Asia & Water & community fabric & 1740 \\
\hline Asia & Water & community fabric & 1999 \\
\hline Asia & Water & community fabric & 2414 \\
\hline Asia & Water & community fabric & 487 \\
\hline Asia & Water & community fabric & 2414 \\
\hline Asia & Water & food \& shelter & 2414 \\
\hline Asia & Water & food \& shelter & 1015 \\
\hline Asia & Water & food \& shelter & 1791 \\
\hline Asia & Water & food \& shelter & 2427 \\
\hline Asia & Water & food \& shelter & 2599 \\
\hline Asia & Water & food \& shelter & 503 \\
\hline Asia & Water & food \& shelter & 836 \\
\hline Asia & Water & food \& shelter & 1999 \\
\hline Asia & Water & food \& shelter & 2414 \\
\hline Asia & Water & food \& shelter & 487 \\
\hline Asia & Water & food \& shelter & 1791 \\
\hline Asia & Water & food \& shelter & 2414 \\
\hline
\end{tabular}




\begin{tabular}{|c|c|c|c|}
\hline World Region & Hazard Type & Response Type & REF ID \\
\hline Asia & Water & governance & 1740 \\
\hline Asia & Water & governance & 179 \\
\hline Asia & Water & governance & 1307 \\
\hline Asia & Water & governance & 1999 \\
\hline Asia & Water & governance & 487 \\
\hline Asia & Water & governance & 557 \\
\hline Asia & Water & green protection & 179 \\
\hline Asia & Water & hard protection & 179 \\
\hline Asia & Water & hard protection & 1023 \\
\hline Asia & Water & hard protection & 1482 \\
\hline Asia & Water & hard protection & 2427 \\
\hline Asia & Water & hard protection & 2599 \\
\hline Asia & Water & hard protection & 836 \\
\hline Asia & Water & hard protection & 487 \\
\hline Asia & Water & hard protection & 557 \\
\hline Asia & Water & info \& data & 2414 \\
\hline Asia & Water & info \& data & 1015 \\
\hline Asia & Water & info \& data & 2427 \\
\hline Asia & Water & info \& data & 1307 \\
\hline Asia & Water & info \& data & 2414 \\
\hline Asia & Water & info \& data & 557 \\
\hline Asia & Water & knowledge \& learning & 179 \\
\hline Asia & Water & knowledge \& learning & 2414 \\
\hline Asia & Water & knowledge \& learning & 1791 \\
\hline Asia & Water & knowledge \& learning & 354 \\
\hline Asia & Water & knowledge \& learning & 557 \\
\hline Asia & Water & knowledge \& learning & 1791 \\
\hline Asia & Water & knowledge \& learning & 1501 \\
\hline Asia & Water & livelihood adaptations & 2414 \\
\hline Asia & Water & livelihood adaptations & 1015 \\
\hline Asia & Water & livelihood adaptations & 503 \\
\hline Asia & Water & mobility & 179 \\
\hline Asia & Water & mobility & 2604 \\
\hline Asia & Water & mobility & 166 \\
\hline Asia & Water & mobility & 2486 \\
\hline Asia & Water & mobility & 1015 \\
\hline Asia & Water & mobility & 136 \\
\hline Asia & Water & mobility & 1791 \\
\hline Asia & Water & mobility & 2427 \\
\hline Asia & Water & mobility & 2486 \\
\hline Asia & Water & mobility & 356 \\
\hline Asia & Water & mobility & 412 \\
\hline Asia & Water & mobility & 503 \\
\hline Asia & Water & mobility & 629 \\
\hline Asia & Water & mobility & 1307 \\
\hline Asia & Water & mobility & 487 \\
\hline Asia & Water & mobility & 1791 \\
\hline Asia & Water & mobility & 331 \\
\hline Asia & Water & money/economic & 813 \\
\hline Asia & Water & money/economic & 2486 \\
\hline Asia & Water & money/economic & 513 \\
\hline Asia & Water & money/economic & 2414 \\
\hline
\end{tabular}




\begin{tabular}{|c|c|c|c|}
\hline World Region & Hazard Type & Response Type & REF ID \\
\hline Asia & Water & money/economic & 2427 \\
\hline Asia & Water & money/economic & 389 \\
\hline Asia & Water & money/economic & 503 \\
\hline Asia & Water & money/economic & 1999 \\
\hline Asia & Water & money/economic & 487 \\
\hline Asia & Water & money/economic & 813 \\
\hline Asia & Water & money/economic & 513 \\
\hline Asia & Water & planning & 1740 \\
\hline Asia & Water & planning & 1023 \\
\hline Asia & Water & planning & 2427 \\
\hline Asia & Water & planning & 2599 \\
\hline Asia & Water & planning & 836 \\
\hline Asia & Water & planning & 557 \\
\hline Asia & Water & protect belongings & 2414 \\
\hline Asia & Water & protect belongings & 1015 \\
\hline Asia & Water & protect belongings & 1482 \\
\hline Asia & Water & protect belongings & 2599 \\
\hline Asia & Water & protect belongings & 836 \\
\hline Asia & Water & psychological & 562 \\
\hline Asia & Water & psychological & 487 \\
\hline Asia & Water & search \& rescue & 1307 \\
\hline Asia & Weather & community fabric & 1740 \\
\hline Asia & Weather & community fabric & 317 \\
\hline Asia & Weather & community fabric & 882 \\
\hline Asia & Weather & community fabric & 1307 \\
\hline Asia & Weather & community fabric & 2414 \\
\hline Asia & Weather & food \& shelter & 1628 \\
\hline Asia & Weather & food \& shelter & 1791 \\
\hline Asia & Weather & food \& shelter & 2486 \\
\hline Asia & Weather & food \& shelter & 2414 \\
\hline Asia & Weather & governance & 1740 \\
\hline Asia & Weather & governance & 147 \\
\hline Asia & Weather & governance & 1626 \\
\hline Asia & Weather & governance & 1628 \\
\hline Asia & Weather & governance & 524 \\
\hline Asia & Weather & governance & 882 \\
\hline Asia & Weather & info \& data & 1628 \\
\hline Asia & Weather & info \& data & 524 \\
\hline Asia & Weather & info \& data & 882 \\
\hline Asia & Weather & info $\&$ data & 2414 \\
\hline Asia & Weather & knowledge \& learning & 1791 \\
\hline Asia & Weather & knowledge \& learning & 2414 \\
\hline Asia & Weather & livelihood adaptations & 2414 \\
\hline Asia & Weather & mobility & 412 \\
\hline Asia & Weather & mobility & 136 \\
\hline Asia & Weather & mobility & 1791 \\
\hline Asia & Weather & mobility & 2486 \\
\hline Asia & Weather & mobility & 331 \\
\hline Asia & Weather & mobility & 629 \\
\hline Asia & Weather & mobility & 846 \\
\hline Asia & Weather & mobility & 2434 \\
\hline Asia & Weather & money/economic & 2486 \\
\hline
\end{tabular}




\begin{tabular}{|c|c|c|c|}
\hline World Region & Hazard Type & Response Type & REF ID \\
\hline Asia & Weather & money/economic & 389 \\
\hline Asia & Weather & money/economic & 513 \\
\hline Asia & Weather & money/economic & 882 \\
\hline Asia & Weather & money/economic & 2414 \\
\hline Asia & Weather & planning & 1740 \\
\hline Asia & Weather & protect belongings & 2414 \\
\hline Asia & Weather & search \& rescue & 1307 \\
\hline Europe & Climate & community fabric & 1061 \\
\hline Europe & Climate & food \& shelter & 1454 \\
\hline Europe & Climate & info \& data & 1454 \\
\hline Europe & Climate & knowledge \& learning & 1454 \\
\hline Europe & Climate & livelihood adaptations & 1454 \\
\hline Europe & Climate & money/economic & 1454 \\
\hline Europe & Earth & governance & 3159 \\
\hline Europe & Earth & green protection & 3159 \\
\hline Europe & Earth & hard protection & 3159 \\
\hline Europe & Earth & info \& data & 3159 \\
\hline Europe & Earth & knowledge \& learning & 154 \\
\hline Europe & Earth & mobility & 3159 \\
\hline Europe & Earth & mobility & 345 \\
\hline Europe & Earth & planning & 298 \\
\hline Europe & Earth & planning & 154 \\
\hline Europe & Water & community fabric & 349 \\
\hline Europe & Water & community fabric & 829 \\
\hline Europe & Water & community fabric & 1454 \\
\hline Europe & Water & community fabric & 3190 \\
\hline Europe & Water & community fabric & 57 \\
\hline Europe & Water & food \& shelter & 2480 \\
\hline Europe & Water & food \& shelter & 472 \\
\hline Europe & Water & food \& shelter & 1454 \\
\hline Europe & Water & governance & 174 \\
\hline Europe & Water & governance & 349 \\
\hline Europe & Water & governance & 472 \\
\hline Europe & Water & governance & 174 \\
\hline Europe & Water & governance & 3190 \\
\hline Europe & Water & governance & 329 \\
\hline Europe & Water & governance & 834 \\
\hline Europe & Water & green protection & 829 \\
\hline Europe & Water & hard protection & 174 \\
\hline Europe & Water & hard protection & 2480 \\
\hline Europe & Water & hard protection & 349 \\
\hline Europe & Water & hard protection & 829 \\
\hline Europe & Water & hard protection & 174 \\
\hline Europe & Water & hard protection & 834 \\
\hline Europe & Water & hard protection & 2666 \\
\hline Europe & Water & info \& data & 2480 \\
\hline Europe & Water & info \& data & 349 \\
\hline Europe & Water & info \& data & 829 \\
\hline Europe & Water & info \& data & 1454 \\
\hline Europe & Water & info \& data & 2134 \\
\hline Europe & Water & info \& data & 3190 \\
\hline Europe & Water & info \& data & 329 \\
\hline
\end{tabular}




\begin{tabular}{|c|c|c|c|}
\hline World Region & Hazard Type & Response Type & REF ID \\
\hline Europe & Water & knowledge \& learning & 2480 \\
\hline Europe & Water & knowledge \& learning & 829 \\
\hline Europe & Water & knowledge \& learning & 1454 \\
\hline Europe & Water & knowledge \& learning & 3190 \\
\hline Europe & Water & knowledge \& learning & 57 \\
\hline Europe & Water & livelihood adaptations & 1454 \\
\hline Europe & Water & mobility & 472 \\
\hline Europe & Water & mobility & 1454 \\
\hline Europe & Water & mobility & 329 \\
\hline Europe & Water & mobility & 43 \\
\hline Europe & Water & money/economic & 2480 \\
\hline Europe & Water & money/economic & 1454 \\
\hline Europe & Water & planning & 174 \\
\hline Europe & Water & planning & 1454 \\
\hline Europe & Water & planning & 174 \\
\hline Europe & Water & planning & 329 \\
\hline Europe & Water & planning & 43 \\
\hline Europe & Water & planning & 57 \\
\hline Europe & Water & protect belongings & 2258 \\
\hline Europe & Water & protect belongings & 2480 \\
\hline Europe & Weather & community fabric & 349 \\
\hline Europe & Weather & hard protection & 2666 \\
\hline Europe & Weather & hard protection & 349 \\
\hline Europe & Weather & info \& data & 349 \\
\hline Caribbean & Climate & community fabric & 2416 \\
\hline Caribbean & Climate & community fabric & 420 \\
\hline Caribbean & Climate & community fabric & 2416 \\
\hline Caribbean & Climate & food \& shelter & 2416 \\
\hline Caribbean & Climate & food \& shelter & 420 \\
\hline Caribbean & Climate & food \& shelter & 2416 \\
\hline Caribbean & Climate & livelihood adaptations & 2558 \\
\hline Caribbean & Climate & livelihood adaptations & 420 \\
\hline Caribbean & Climate & money/economic & 2416 \\
\hline Caribbean & Climate & money/economic & 420 \\
\hline Caribbean & Climate & money/economic & 2416 \\
\hline Caribbean & Climate & other social & 420 \\
\hline Caribbean & Climate & planning & 2416 \\
\hline Caribbean & Climate & protect belongings & 2416 \\
\hline Caribbean & Earth & community fabric & 2416 \\
\hline Caribbean & Earth & community fabric & 2489 \\
\hline Caribbean & Earth & community fabric & 2416 \\
\hline Caribbean & Earth & food \& shelter & 2416 \\
\hline Caribbean & Earth & governance & 345 \\
\hline Caribbean & Earth & governance & 2656 \\
\hline Caribbean & Earth & green protection & 2622 \\
\hline Caribbean & Earth & hard protection & 2651 \\
\hline Caribbean & Earth & hard protection & 2441 \\
\hline Caribbean & Earth & hard protection & 2622 \\
\hline Caribbean & Earth & hard protection & 2656 \\
\hline Caribbean & Earth & info \& data & 1771 \\
\hline Caribbean & Earth & info \& data & 2489 \\
\hline Caribbean & Earth & info \& data & 2622 \\
\hline
\end{tabular}




\begin{tabular}{|c|c|c|c|}
\hline World Region & Hazard Type & $\begin{array}{l}\text { Response Type } \\
\end{array}$ & REF ID \\
\hline Caribbean & Earth & knowledge \& learning & 2489 \\
\hline Caribbean & Earth & knowledge \& learning & 2656 \\
\hline Caribbean & Earth & mobility & 2441 \\
\hline Caribbean & Earth & mobility & 2489 \\
\hline Caribbean & Earth & mobility & 2622 \\
\hline Caribbean & Earth & mobility & 890 \\
\hline Caribbean & Earth & money/economic & 2416 \\
\hline Caribbean & Earth & money/economic & 2441 \\
\hline Caribbean & Earth & money/economic & 2416 \\
\hline Caribbean & Earth & planning & 2416 \\
\hline Caribbean & Earth & planning & 2622 \\
\hline Caribbean & Earth & planning & 2416 \\
\hline Caribbean & Water & community fabric & 345 \\
\hline Caribbean & Water & community fabric & 1573 \\
\hline Caribbean & Water & community fabric & 2416 \\
\hline Caribbean & Water & food \& shelter & 2416 \\
\hline Caribbean & Water & governance & 1029 \\
\hline Caribbean & Water & hard protection & 554 \\
\hline Caribbean & Water & hard protection & 1029 \\
\hline Caribbean & Water & hard protection & 1440 \\
\hline Caribbean & Water & hard protection & 2416 \\
\hline Caribbean & Water & hard protection & 90 \\
\hline Caribbean & Water & info \& data & 820 \\
\hline Caribbean & Water & info \& data & 1440 \\
\hline Caribbean & Water & info \& data & 1771 \\
\hline Caribbean & Water & knowledge \& learning & 1573 \\
\hline Caribbean & Water & knowledge \& learning & 190 \\
\hline Caribbean & Water & knowledge \& learning & 1440 \\
\hline Caribbean & Water & money/economic & 2416 \\
\hline Caribbean & Water & planning & 1029 \\
\hline Caribbean & Water & planning & 2416 \\
\hline Caribbean & Water & protect belongings & 554 \\
\hline Caribbean & Water & protect belongings & 2416 \\
\hline Caribbean & Water & psychological & 1573 \\
\hline Caribbean & Weather & community fabric & 1475 \\
\hline Caribbean & Weather & community fabric & 939 \\
\hline Caribbean & Weather & food \& shelter & 1623 \\
\hline Caribbean & Weather & food \& shelter & 2416 \\
\hline Caribbean & Weather & food \& shelter & 939 \\
\hline Caribbean & Weather & governance & 495 \\
\hline Caribbean & Weather & green protection & 1623 \\
\hline Caribbean & Weather & hard protection & 2441 \\
\hline Caribbean & Weather & hard protection & 1623 \\
\hline Caribbean & Weather & hard protection & 2416 \\
\hline Caribbean & Weather & knowledge \& learning & 1623 \\
\hline Caribbean & Weather & livelihood adaptations & 1475 \\
\hline Caribbean & Weather & livelihood adaptations & 2805 \\
\hline Caribbean & Weather & mobility & 2441 \\
\hline Caribbean & Weather & money/economic & 2441 \\
\hline Caribbean & Weather & money/economic & 1475 \\
\hline Caribbean & Weather & money/economic & 2441 \\
\hline Caribbean & Weather & money/economic & 1623 \\
\hline
\end{tabular}




\begin{tabular}{|c|c|c|c|}
\hline World Region & Hazard Type & Response Type & REF ID \\
\hline Caribbean & Weather & money/economic & 2416 \\
\hline Caribbean & Weather & money/economic & 2805 \\
\hline Caribbean & Weather & planning & 2416 \\
\hline Caribbean & Weather & protect belongings & 2416 \\
\hline Caribbean & Weather & protect belongings & 2805 \\
\hline Northern America & Climate & community fabric & 408 \\
\hline Northern America & Climate & knowledge \& learning & 1036 \\
\hline Northern America & Climate & knowledge \& learning & 603 \\
\hline Northern America & Climate & mobility & 181 \\
\hline Northern America & Climate & mobility & 153 \\
\hline Northern America & Climate & mobility & 196 \\
\hline Northern America & Earth & community fabric & 345 \\
\hline Northern America & Earth & mobility & 345 \\
\hline Northern America & Water & community fabric & 408 \\
\hline Northern America & Water & community fabric & 499 \\
\hline Northern America & Water & community fabric & 744 \\
\hline Northern America & Water & community fabric & 565 \\
\hline Northern America & Water & community fabric & 408 \\
\hline Northern America & Water & food \& shelter & 744 \\
\hline Northern America & Water & governance & 2673 \\
\hline Northern America & Water & governance & 1990 \\
\hline Northern America & Water & governance & 2051 \\
\hline Northern America & Water & governance & 496 \\
\hline Northern America & Water & governance & 744 \\
\hline Northern America & Water & governance & 1008 \\
\hline Northern America & Water & hard protection & 858 \\
\hline Northern America & Water & hard protection & 1993 \\
\hline Northern America & Water & hard protection & 2051 \\
\hline Northern America & Water & hard protection & 1008 \\
\hline Northern America & Water & info $\&$ data & 496 \\
\hline Northern America & Water & info \& data & 744 \\
\hline Northern America & Water & mobility & 121 \\
\hline Northern America & Water & mobility & 858 \\
\hline Northern America & Water & mobility & 1008 \\
\hline Northern America & Water & money/economic & 1008 \\
\hline Northern America & Water & other social & 744 \\
\hline Northern America & Water & planning & 499 \\
\hline Northern America & Water & planning & 744 \\
\hline Northern America & Water & planning & 1008 \\
\hline Northern America & Water & protect belongings & 744 \\
\hline Northern America & Weather & community fabric & 2287 \\
\hline Northern America & Weather & community fabric & 995 \\
\hline Northern America & Weather & community fabric & 2516 \\
\hline Northern America & Weather & community fabric & 633 \\
\hline Northern America & Weather & food \& shelter & 995 \\
\hline Northern America & Weather & food \& shelter & 2516 \\
\hline Northern America & Weather & food \& shelter & 633 \\
\hline Northern America & Weather & governance & 1990 \\
\hline Northern America & Weather & governance & 2612 \\
\hline Northern America & Weather & governance & 496 \\
\hline Northern America & Weather & governance & 1646 \\
\hline Northern America & Weather & governance & 2147 \\
\hline
\end{tabular}




\begin{tabular}{|c|c|c|c|}
\hline World Region & Hazard Type & Response Type & REF ID \\
\hline Northern America & Weather & green protection & 2023 \\
\hline Northern America & Weather & hard protection & 1657 \\
\hline Northern America & Weather & hard protection & 1993 \\
\hline Northern America & Weather & hard protection & 2110 \\
\hline Northern America & Weather & hard protection & 1646 \\
\hline Northern America & Weather & hard protection & 2667 \\
\hline Northern America & Weather & info \& data & 2042 \\
\hline Northern America & Weather & info \& data & 995 \\
\hline Northern America & Weather & knowledge \& learning & 633 \\
\hline Northern America & Weather & mobility & 159 \\
\hline Northern America & Weather & mobility & 1829 \\
\hline Northern America & Weather & mobility & 196 \\
\hline Northern America & Weather & mobility & 2042 \\
\hline Northern America & Weather & mobility & 2137 \\
\hline Northern America & Weather & mobility & 496 \\
\hline Northern America & Weather & mobility & 995 \\
\hline Northern America & Weather & mobility & 1008 \\
\hline Northern America & Weather & mobility & 1646 \\
\hline Northern America & Weather & mobility & 1654 \\
\hline Northern America & Weather & mobility & 1953 \\
\hline Northern America & Weather & mobility & 2003 \\
\hline Northern America & Weather & mobility & 633 \\
\hline Northern America & Weather & money/economic & 2036 \\
\hline Northern America & Weather & money/economic & 995 \\
\hline Northern America & Weather & money/economic & 1008 \\
\hline Northern America & Weather & other social & 2612 \\
\hline Northern America & Weather & other social & 995 \\
\hline Northern America & Weather & planning & 2042 \\
\hline Northern America & Weather & planning & 693 \\
\hline Northern America & Weather & planning & 1646 \\
\hline Northern America & Weather & psychological & 1997 \\
\hline Northern America & Weather & psychological & 2612 \\
\hline Northern America & Weather & psychological & 2516 \\
\hline Northern America & Weather & psychological & 633 \\
\hline Oceania & Climate & community fabric & 1468 \\
\hline Oceania & Climate & food \& shelter & 1468 \\
\hline Oceania & Climate & food \& shelter & 2247 \\
\hline Oceania & Climate & governance & 1468 \\
\hline Oceania & Climate & governance & 658 \\
\hline Oceania & Climate & livelihood adaptations & 1468 \\
\hline Oceania & Climate & mobility & 2247 \\
\hline Oceania & Climate & mobility & 153 \\
\hline Oceania & Climate & mobility & 2500 \\
\hline Oceania & Climate & mobility & 2557 \\
\hline Oceania & Climate & planning & 2557 \\
\hline Oceania & Earth & community fabric & 899 \\
\hline Oceania & Earth & community fabric & 1333 \\
\hline Oceania & Earth & community fabric & 592 \\
\hline Oceania & Earth & community fabric & 345 \\
\hline Oceania & Earth & food $\&$ shelter & 899 \\
\hline Oceania & Earth & governance & 592 \\
\hline Oceania & Earth & info \& data & 592 \\
\hline
\end{tabular}




\begin{tabular}{|c|c|c|c|}
\hline World Region & Hazard Type & Response Type & REF ID \\
\hline Oceania & Earth & mobility & 899 \\
\hline Oceania & Earth & mobility & 1333 \\
\hline Oceania & Earth & other social & 592 \\
\hline Oceania & Earth & psychological & 899 \\
\hline Oceania & Earth & search \& rescue & 592 \\
\hline Oceania & Water & community fabric & 2495 \\
\hline Oceania & Water & governance & 1800 \\
\hline Oceania & Water & green protection & 1800 \\
\hline Oceania & Water & hard protection & 1800 \\
\hline Oceania & Water & hard protection & 3141 \\
\hline Oceania & Water & mobility & 2495 \\
\hline Oceania & Water & money/economic & 3141 \\
\hline Oceania & Water & psychological & 1800 \\
\hline Oceania & Weather & community fabric & 1468 \\
\hline Oceania & Weather & community fabric & 1800 \\
\hline Oceania & Weather & community fabric & 345 \\
\hline Oceania & Weather & food \& shelter & 1468 \\
\hline Oceania & Weather & food \& shelter & 1649 \\
\hline Oceania & Weather & food \& shelter & 2247 \\
\hline Oceania & Weather & governance & 1468 \\
\hline Oceania & Weather & governance & 345 \\
\hline Oceania & Weather & green protection & 1800 \\
\hline Oceania & Weather & hard protection & 1468 \\
\hline Oceania & Weather & info \& data & 1649 \\
\hline Oceania & Weather & knowledge \& learning & 1649 \\
\hline Oceania & Weather & knowledge \& learning & 1800 \\
\hline Oceania & Weather & livelihood adaptations & 1468 \\
\hline Oceania & Weather & livelihood adaptations & 345 \\
\hline Oceania & Weather & mobility & 2247 \\
\hline Oceania & Weather & money/economic & 345 \\
\hline
\end{tabular}


Refworks Export Tagged Format

Character Set=utf-8

Tag legend

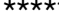

RT=Reference Type

SR=Source Type

ID=Reference Identifier

A1=Primary Authors

T1=Primary Title

JF=Periodical Full

$\mathrm{JO}=$ Periodical Abbrev

YR=Publication Year

$\mathrm{FD}=$ Publication Data,Free Form

$\mathrm{VO}=$ Volume

IS=Issue

$\mathrm{SP}=$ Start Page

$\mathrm{OP}=$ Other Pages

$\mathrm{K} 1=$ Keyword

$\mathrm{AB}=$ Abstract

$\mathrm{NO}=$ Notes

$\mathrm{A} 2=$ Secondary Authors

T2=Secondary Title

$\mathrm{ED}=$ Edition

$\mathrm{PB}=$ Publisher

$\mathrm{PP}=$ Place of Publication

A3=Tertiary Authors

A4=Quaternary Authors

A5=Quinary Authors

T3=Tertiary Title

$\mathrm{SN}=\mathrm{ISSN} / \mathrm{ISBN}$

$\mathrm{AV}=$ Availability

$A D=$ Author Address

$\mathrm{AN}=$ Accession Number

$L A=$ Language

$\mathrm{CL}=$ Classification

SF=Subfile/Database

OT=Original Foreign Title

LK=Links

$\mathrm{DO}=$ Document Object Index

$\mathrm{CN}=$ Call Number

$\mathrm{DB}=$ Database

DS=Data Source

IP=Identifying Phrase

$\mathrm{RD}=$ Retrieved Date

ST=Shortened Title

$\mathrm{U} 1=$ User 1

U2=User 2

U3=User 3

$\mathrm{U} 4=\mathrm{User} 4$

U5=User 5

U6=User 6 
$\mathrm{U} 7=\mathrm{User} 7$

U8=User 8

U9=User 9

U10=User 10

U11=User 11

U12=User 12

U13=User 13

U14=User 14

U15=User 15

$\mathrm{UL}=\mathrm{URL}$

SL=Sponsoring Library

$\mathrm{LL}=$ Sponsoring Library Location

$\mathrm{CR}=$ Cited References

WT $=$ Website Title

A6=Website Editor

$\mathrm{WV}=$ Website Version

WP=Date of Electronic Publication

$\mathrm{OL}=$ Output Language

PMID=PMID

$P M C I D=P M C I D$

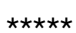

Font Attribute Legend

Start Bold $=$

End Bold =

Start Underline $=$

End Underline =

Start Italic $=$

End Italic =

Start SuperScript $=$

End SuperScript =

Start SubScript $=$

End SubScript =

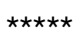

BEGIN EXPORTED REFERENCES

RT Journal Article

SR Print(0)

ID 2673

A1 Abbott,Thorne

T1 Shifting shorelines and political winds - The complexities of implementing the simple idea of shoreline setbacks for oceanfront developments in Maui, Hawaii

JF Ocean \& Coastal Management

JO Ocean Coast.Manage.

YR 2013

FD 3

VO 73

IS 0

SP 13

OP 21 
SN 0964-5691

LK file://C:/Users/s9130263/Documents/Cases/Abbott_2013.pdf;

DO http://dx.doi.org/10.1016/j.ocecoaman.2012.12.010

DS ScienceDirect

UL http://www.sciencedirect.com/science/article/pii/S0964569112003353

OL Unknown(0)

RT Journal Article

SR Print(0)

ID 2456

A1 Adiyoso,Wignyo

A1 Kanegae,Hidehiko

T1 The Preliminary Study of the Role of Islamic Teaching in the Disaster Risk Reduction (A

Qualitative Case Study of Banda Aceh, Indonesia)

JF Procedia Environmental Sciences

YR 2013

VO 17

IS 0

SP 918

OP 927

K1 Islamic

K1 teaching

$\mathrm{K} 1$ religion

K1 natural

K1 disaster

K1 god's wrath

T2 The 3rd International Conference on Sustainable Future for Human Security, SUSTAIN 2012,

3-5 November 2012, Clock Tower Centennial Hall, Kyoto University, JAPAN

SN 1878-0296

LK C:IUsers\s9130263\Documents\Cases\Adioso_\&_Kanegae_2013.pdf

DO http://dx.doi.org/10.1016/j.proenv.2013.02.110

DS ScienceDirect

UL http://www.sciencedirect.com/science/article/pii/S1878029613001126

OL Unknown(0)

RT Journal Article

SR Print(0)

ID 2567

A1 Ainuddin,Syed

A1 Mukhtar,Uzma

A1 Ainuddin,Shabana

T1 Public perception about enforcement of building codes as risk reduction strategy for seismic safety in Quetta, Baluchistan

JF International Journal of Disaster Risk Reduction

IS 0

K1 Building codes

K1 Enforcement

K1 Local institutions

K1 Baluchistan

K1 Seismic safety

SN 2212-4209

DO http://dx.doi.org/10.1016/j.ijdrr.2014.04.007

DS ScienceDirect

UL http://www.sciencedirect.com/science/article/pii/S2212420914000363 
OL Unknown(0)

RT Journal Article

SR Print(0)

ID 2414

A1 Alam,Khurshed

A1 Rahman,Md Habibur

T1 Women in natural disasters: A case study from southern coastal region of Bangladesh

JF International Journal of Disaster Risk Reduction

YR 2014

FD 6

VO 8

IS 0

SP 68

OP 82

K1 Disaster warning

K1 Environmental hazard

K1 Disaster preparedness

$\mathrm{K} 1$ Disaster gain

K1 Coping strategy

K1 Recovery capacity

SN 2212-4209

LK file://C:/Users/s9130263/Documents/Cases/Alam_\&_Rahman_2014.pdf

DO http://dx.doi.org/10.1016/j.ijdrr.2014.01.003

DS ScienceDirect

UL http://www.sciencedirect.com/science/article/pii/S2212420914000041

OL Unknown(0)

RT Journal Article

SR Print(0)

ID 1771

A1 Alcantara-Ayala,I.

A1 Lopez-Mendoza,M.

A1 Melgarejo-Palafox,G.

A1 Borja-Baeza,R. C.

A1 Acevo-Zarate,R.

T1 Natural Hazards and Risk Communication Strategies Among Indigenous Communities JF Mountain Research and Development

YR 2004

FD Nov 2004

VO 24

IS 4

SP 298

OP 302

K1 Earth Sciences

$\mathrm{K} 1 \mathrm{OB}$

K1 1B

AB Attempts to improve risk communication strategies in order to prevent and mitigate disasters caused by natural hazards have been made worldwide. However, most such strategies target non-indigenous populations, while vulnerable communities located in remote mountain areas in the least developed countries lack information in their native language. Awareness of risks associated with flooding and rainfall-induced landslides increased as a result of the tragedy in autumn 1999 in the Sierra Norte de Puebla, Mexico, where loods and landslides devastated dozens of municipalities, claiming more than 200 lives. Consequently, a 
booklet and a radio message focusing on awareness and preparedness in the event of landslides were produced in Nahuatl, the Aztec language, as an accessibility tool to help prevent and mitigate disasters in indigenous communities. Findings from a preliminary acceptance evaluation undertaken in a local community are analyzed and discussed as an initial approach to developing a sound risk communication strategy based on local knowledge. NO Source type: scholarlyjournals; Object type: Article; Object type: Feature; CSAUnique: OBMD-0010281949; AccNum: 6124288; DOI: 10.1043/0276-4741(2004)0242.0.CO;2; ISSN:

0276-4741; Peer Reviewed: true

PB International Mountain Society

PP Japan

SN 0276-4741

AN 288979092; 6124288

LA English

LK file:///C:/Users/s9130263/Documents/Cases/Alc\%C3\%A1ntara-Ayala_2004.pdf

DO http://dx.doi.org/10.1043/0276-4741(2004)024<0298:NHARCS>2.0.CO;2

DB GeoRef

DS ProQuest

UL http://QN8PM6GK2Q.search.serialssolutions.com/directLink?

\&atitle=Natural+Hazards+and+Risk+Communication+Strategies+Among+Indigenous+Commun ities\&author=Alcantara-Ayala\%252C+l\%253BLopez-Mendoza\%252C+M\%253BMelgarejo-

Palafox\%252C+G\%253BBorja-Baeza\%252C+R+C\%253BAcevo-

Zarate\%252C+R\&issn=02764741\&title=Mountain+Research+and+Development\&volume=24\&i

ssue $=4 \&$ date $=2004-11-01 \&$ spage $=298 \&$ id $=$ doi:

10.1043\%252F0276-4741\%25282004\%25290242.0.CO\%253B2\&sid=ProQ_ss\&genre=article; http://journals.allenpress.com/jrnlserv/?request=get-

abstract\&issn=0276-4741\&volume=24\&page=298; http://dx.doi.org/

10.1043/0276-4741(2004)024<0298:NHARCS>2.0.CO; http://journals.allenpress.com/jrnlserv/? request $=$ get-abstract\&issn $=0276-4741 \&$ volume $=24 \&$ page $=298$

OL Unknown(0)

RT Journal Article

SR Print(0)

ID 2147

A1 Allen,Barbara L.

T1 Environmental Justice and Expert Knowledge in the Wake of a Disaster

JF Social Studies of Science

JO Soc.Stud.Sci.

YR 2007

FD Feb.

VO 37

IS 1

SP 103

OP 110

PB Sage Publications, Ltd.

SN 03063127

LA English

SF research-article; Copyright (C) 2007 Sage Publications, Ltd.

LK file://C:/Users/s9130263/Documents/Cases/Allen_2007.pdf

DS JSTOR

OL Unknown(0)

RT Journal Article

SR Print(0)

ID 329 
A1 Andrew,Robin Matthew

A1 Knight, Kerry Lisa

T1 Briefing: Plan, predict and be proactive - Lostwithiel, UK floods case study

JF Proceedings of ICE: Water Management

YR 2014

FD 01

VO 167

IS 1

SP 2

OP 4

K1 FLOODS

K1 GOVERNMENT agencies

K1 PREDICTION theory

K1 EMERGENCY management

K1 SOCIAL impact

K1 GREAT Britain

K1 CASE studies

K1 floods \& floodworks

K1 local government

AB This article is based on the flood events in Cornwall, UK, in November and December 2012, and takes forward the arguments presented in a paper entitled 'Building community resilience' published in November 2012. It uses a case study in Lostwithiel, Cornwall, to argue that if public agencies and local communities work and plan together, using all available data, then proactive steps can be taken to build resilience that assists in both the response and recovery stage of major incidents to minimise the direct impacts of floods and ensure that communities can return to normal as soon as possible after an event. This article also highlights some of the wider impacts that need to be considered when planning for emergencies ABSTRACT FROM AUTHOR]; Copyright of Proceedings of ICE: Water Management is the property of Thomas Telford Ltd and its content may not be copied or emailed to multiple sites or posted to a listserv without the copyright holder's express written permission. However, users may print, download, or email articles for individual use. This abstract may be abridged. No warranty is given about the accuracy of the copy. Users should refer to the original published version of the material for the full abstract. (Copyright applies to all Abstracts.)

NO M3: Article

SN 17417589

AN 92776738

LK http://library.smu.ca:2048/login?http://search.ebscohost.com/login.aspx?

direct $=$ true $\& \mathrm{db}=a p h \& A N=92776738 \&$ site=ehost-live

DO 10.1680/wama.13.00024

DS EBSCO

OL Unknown(0)

RT Journal Article

SR Print(0)

ID 189

A1 Badri,S. Ali

A1 Asgary,Ali

A1 Eftekhari,A. R.

A1 Levy,Jason

T1 Post-disaster resettlement, development and change: A case study of the 1990 Manjil earthquake in Iran

JF Disasters

JO Disasters

YR 2006 
VO 30

IS 4

SP 451

$\mathrm{K} 1$ developing world

$\mathrm{K} 1$ disaster management

$\mathrm{K} 1$ earthquake event

K1 reconstruction

$\mathrm{K} 1$ relocation

K1 resettlement policy

$\mathrm{K} 1$ socioeconomic conditions

K1 socioeconomic impact

AB Planned and involuntary resettlement after natural disasters has been a major policy in post-disaster reconstruction in developing countries over the past few decades. Studies show that resettlement can result in significant adverse impacts on the resettled population.

Conversely, a well-planned and managed resettlement process can produce positive long-term development outcomes. This article presents the results of a case study undertaken 11 years after the 1990 Manjil earthquake in Iran. During the reconstruction period, a policy of involuntary planned resettlement was pursued extensively. The socioeconomic changes that occurred as a consequence of this policy of involuntary resettlement are analysed. Data were collected via a questionnaire survey that involved a sample of 194 relocated households (grouped into a settlement that later became a town). The paper shows that relocated families face difficult socioeconomic challenges after relocation and regrouping. This is especially true with respect to employment, income, the empowerment of women and lifestyle issues. \&copy; Overseas Development Institute, 2006.

SN 03613666

LA English

LK file:///C:/Users/s9130263/Documents/Cases/Badri_etal_2006.pdf

DB Compilation and indexing terms, Copyright 2013 Elsevier Inc.; GEOBASE

OL Unknown(0)

RT Journal Article

SR Print(0)

ID 35

A1 Bakhit A.H.M.A. ,

T1 The subsistence crisis and migration in the Sahelian zone of the Sudan - a case-study of Burush Village, Darfur

JF GeoJournal

JO GeoJournal

VO 25

IS 1

SP 39

OP 45

SN 0343-2521

LA eng

DB /z-wcorg/

DS http://worldcat.org

OL Unknown(0)

RT Journal Article

SR Print(0)

ID 60

A1 Bakhit,A. H. M. A.

T1 The subsistence crisis and migration in the Sahelian zone of the Sudan - a case-study of Burush Village, Darfur 
JF GeoJournal

JO GeoJournal

YR 1991

VO 25

IS 1

SP 39

K1 coping mechanism

$\mathrm{K} 1$ developing country

K1 drought conditions

$\mathrm{K} 1$ migration

K1 migration response

$\mathrm{K} 1$ population change

$\mathrm{K} 1$ rural area

$\mathrm{K} 1$ seasonal labour migration

$\mathrm{K} 1$ subsistence crisis

K1 survival strategy

$A B$ Burush is a small village in the N Sahelian zone of the Sudan, whose population are basically sedentary agriculturists. The recurring drought conditions of the last two decades have significantly influenced the local resource base, so that the subsistence of the majority of the households was highly challenged. Nevertheless, the people are still surviving and resisting. The explanation of this resistance can be sought in the endogenous coping mechanisms adopted by the people. One of these mechanisms is migration, especially the seasonal labour migration of the heads and grown-up members of households, which used, even in good years, to be highly integrated in the strategies of survival of the majority of households. However under the recurring crop failures and the growing competition in the seasonal labour opportunities, this seasonal migration is changing gradually into stays of longer duration in the traditional destinations of seasonal labour. On the other hand, the male members of households are actively involved in migration of long duration, especially into the urban centres. Yet, the contributions of these migrant members to the subsistence of their households are limited, because of the rising costs of living in urban centres as compared with the incomes. The rehabilitation of Burush lies obviously in the development of long-term strategies which aim at strengthening the endogenous resilience mechanisms. -Author SN 03432521

LA English

DB Compilation and indexing terms, Copyright 2013 Elsevier Inc.; GEOBASE

OL Unknown(0)

RT Journal Article

SR Print(0)

ID 390

A1 Balgos, Benigno

A1 Gaillard,J. C.

A1 Sanz, Kristinne

T1 The warias of Indonesia in disaster risk reduction: the case of the $2010 \mathrm{Mt}$ Merapi eruption in Indonesia

JF Gender \& Development

YR 2012

FD 07

VO 20

IS 2

SP 337

OP 348

K1 LGBT people

K1 NATURAL disasters 
K1 LGBT communities

K1 CHARITIES

K1 VOLCANIC eruptions

K1 INTERVIEWS

K1 INDONESIA

K1 capacity

$\mathrm{K} 1$ disaster risk reduction

$\mathrm{K} 1$ humanitarian action

K1 LGBT

$\mathrm{K} 1$ vulnerability

$\mathrm{K} 1$ waria

AB This field note draws upon the concepts of vulnerability, marginalisation, and capacity of lesbian, gay, bisexual, and transgender (LGBT) people to face natural hazards. As a case study, this paper highlights the response of warias, members of the LGBT community in Indonesia, during the $2010 \mathrm{Mt}$ Merapi eruption. Through key informant interviews and observation of actual relief operations led by warias in several evacuation sites in Yogyakarta and Central Java, the paper highlights that warias contributed to disaster risk reduction (DRR) even though they are marginalised and discriminated in the country because of prevailing religious and societal attitudes. The paper argues that their needs and capacities should be acknowledged in DRR policies and practice. ABSTRACT FROM AUTHOR]; Copyright of Gender \& Development is the property of Routledge and its content may not be copied or emailed to multiple sites or posted to a listserv without the copyright holder's express written permission. However, users may print, download, or email articles for individual use. This abstract may be abridged. No warranty is given about the accuracy of the copy. Users should refer to the original published version of the material for the full abstract. (Copyright applies to all Abstracts.)

NO M3: Article

SN 13552074

AN 77330509

LK http://library.smu.ca:2048/login?http://search.ebscohost.com/login.aspx? direct $=$ true $\& \mathrm{db}=a p h \& A N=77330509 \&$ site $=$ ehost-live

DO 10.1080/13552074.2012.687218

DS EBSCO

OL Unknown(0)

RT Journal Article

SR Print(0)

ID 1307

A1 BANKOFF,GREG

T1 Storm over San Isidro: 'Civic Community' and Disaster Risk Reduction in the Nineteenth Century Philippines

JF Journal of Historical Sociology

YR 2012

FD 09

VO 25

IS 3

SP 331

OP 351

K1 NATURAL disasters

K1 FLOODS

K1 CIVIL society

K1 COMMUNITY involvement

K1 COMMUNITY life

K1 CYCLONES 
K1 PHILIPPINES -- Social life \& customs

K1 PHILIPPINES

K1 TROPICS

$A B$ Using a detailed archival account of a typhoon-induced flood, this paper examines Disaster Risk Reduction (DRR) as practised in a late nineteenth century provincial town in the Philippines. Culture is an important determinant when considering DRR for any community as the roots of its present-day resilience as well as the causes of its vulnerabilities may lie in its history. The flood of 1887 and the account of the actions taken by the community in San Isidro challenge any assumptions about DRR in the past and hint at the origins of the vibrant civil society that is such a characteristic of Filipino society today. ABSTRACT FROM AUTHOR]; Copyright of Journal of Historical Sociology is the property of Wiley-Blackwell and its content may not be copied or emailed to multiple sites or posted to a listserv without the copyright holder's express written permission. However, users may print, download, or email articles for individual use. This abstract may be abridged. No warranty is given about the accuracy of the copy. Users should refer to the original published version of the material for the full abstract. (Copyright applies to all Abstracts.)

NO M3: Article

SN 09521909

AN 79823477

LK file://C:/Users/s9130263/Documents/Cases/Bankoff_2012.pdf

DO 10.1111/j.1467-6443.2012.01422.x

DS EBSCO

OL Unknown(0)

RT Journal Article

SR Print(0)

ID 1683

A1 Barbier,Edward B.

T1 Natural barriers to natural disasters: replanting mangroves after the tsunami JF Frontiers in Ecology \& the Environment

YR 2006

FD 04

VO 4

IS 3

SP 124

OP 131

K1 NATURAL disasters

K1 ENVIRONMENTAL degradation

K1 DEFORESTATION

K1 MANGROVE plants

K1 FORESTS \& forestry

K1 FARM management

K1 FOREST plants

K1 HALOPHYTES

K1 CRISIS management

K1 THAILAND

AB The Indian Ocean tsunami disaster of December 2004 has increased interest in replanting degraded and deforested mangrove areas in Asia to improve coastal protection. Evidence from Thailand suggests that concern over mangrove deforestation by shrimp farms is an important motivation for many coastal households to participate in mangrove rehabilitation. However, successful re-establishment and management of mangroves as effective coastal barriers will require developing new institutions and policies, and must involve coastal communities in Thailand and other Indian Ocean countries in the conservation and protection of their local mangrove forests. ABSTRACT FROM AUTHOR]; Copyright of Frontiers in Ecology \& the 
Environment is the property of Ecological Society of America and its content may not be copied or emailed to multiple sites or posted to a listserv without the copyright holder's express written permission. However, users may print, download, or email articles for individual use. This abstract may be abridged. No warranty is given about the accuracy of the copy. Users should refer to the original published version of the material for the full abstract. (Copyright applies to all Abstracts.)

NO M3: Article

SN 15409295

AN 20474539

LK file://C:/Users/s9130263/Documents/Cases/Barbier_2006.pdf

DS EBSCO

OL Unknown(0)

RT Journal Article

SR Print(0)

ID 1501

A1 Barua,Anamika

A1 Katyaini,Suparana

A1 Mili,Bhupen

A1 Gooch,Pernille

T1 Climate change and poverty: building resilience of rural mountain communities in South

Sikkim, Eastern Himalaya, India

JF Regional Environmental Change

YR 2014

FD 02

VO 14

IS 1

SP 267

OP 280

K1 CLIMATIC changes -- Environmental aspects

K1 POVERTY -- Economic aspects

K1 POVERTY rate

K1 POVERTY -- Research

K1 SIKKIM (India) -- Social conditions

K1 Climate change

K1 Multidimensional poverty assessment tool

K1 Poverty

K1 Resilience

$A B$ The rural mountain communities have long faced challenges from a range of social, economic, political and environmental factors and the threat from these factors has only intensified due to the current climate change. This study was conducted in South Sikkim, a mountain region located in the Indian Eastern Himalaya, to get a deeper insight of the multitude of barriers and stresses that a poor rural mountain community experiences. The purpose of the study was to get community's perception on the kind of interventions that they consider important to lift them out of poverty and enhance their resilience to manage climate risk. The analysis is based on focus group discussions and household survey, using a multidimensional poverty assessment tool. The study highlights that the vulnerability of the study region to climate change is not concentrated to physical or geographical factors alone, but mostly to the socio-economic factors like lack of access to education, health care, limited livelihood opportunities, limited resources, etc. People consider that these non-climatic factors act as barriers for them to overcome poverty, contribute to their weak resilience, and make it extremely difficult for them to manage the risk posed by climate change. The study therefore suggests that it is of utmost importance that the interventions are planned in ways that address the multidimensional poverty in the region which in turn will enhance community's inherent 
capacity to adapt to current as well as future climate risk. ABSTRACT FROM AUTHOR]; Copyright of Regional Environmental Change is the property of Springer Science \& Business Media B.V. and its content may not be copied or emailed to multiple sites or posted to a listserv without the copyright holder's express written permission. However, users may print, download, or email articles for individual use. This abstract may be abridged. No warranty is given about the accuracy of the copy. Users should refer to the original published version of the material for the full abstract. (Copyright applies to all Abstracts.)

NO M3: Article

SN 14363798

AN 94007566

LK file://C:/Users/s9130263/Documents/Cases/bARUA_etal_2014.pdf

DO 10.1007/s10113-013-0471-1

DS EBSCO

OL Unknown(0)

RT Journal Article

SR Print(0)

ID 2134

A1 Baxter,Peter J.

T1 The East Coast Big Flood, 31 January-1 February 1953: A Summary of the Human Disaster JF Philosophical Transactions: Mathematical, Physical and Engineering Sciences

YR 2005

FD Jun.

VO 363

IS 1831, The Big Flood: North Sea storm surge

SP 1293

OP 1312

$\mathrm{AB}$ The Big Flood was the worst natural disaster to befall Britain during the twentieth century, and the scale of its human impact was due to the lack of adequate disaster preparedness. The 307 deaths on land were caused by drowning or from the effects of exposure. Two-thirds occurred in four clusters along the shoreline and mainly comprised inhabitants of post-war prefabricated buildings, bungalows and chalets, with the highest mortality among the elderly. The emergency response was spontaneous and community led, with the main search and rescue completed before central government became involved. No individuals or agencies were blamed for the neglected state of the flood defences or the absence of warnings, along with the post-war shortage of adequate housing, which were the main causes of vulnerability. The media played a limited role, and television was in its infancy. Mental health impacts were either self-limiting or failed to be articulated in a society recovering from the Second World War. The major mitigating factors included the empathetic response of people, locally and nationally, as well as the availability of armed forces personnel based in East Anglia, whose actions played a decisive part in the battle against the sea. The major legacies of the Big Flood were a coastal flood forecasting system, a more scientific approach to sea defences and the building of the Thames barrier.

PB The Royal Society

SN 1364503X

LA English

SF research-article; Copyright (C) 2005 The Royal Society

LK file://C:/Users/s9130263/Documents/Cases/Baxter_2005.pdf

DS JSTOR

OL Unknown(0)

RT Journal Article

SR Print(0)

ID 3159 
A1 Bertolaso,G.

A1 De Bernardinis,B.

A1 Bosi,V.

A1 Cardaci,C.

A1 Ciolli,S.

A1 Colozza, R.

A1 Cristiani,C.

A1 Mangione,D.

A1 Ricciardi,A.

A1 Rosi,M.

A1 Scalzo,A.

A1 Soddu,P.

T1 Civil protection preparedness and response to the 2007 eruptive crisis of Stromboli volcano, Italy

JF Journal of Volcanology and Geothermal Research

JO J.Volcanol.Geotherm.Res.

YR 2009

FD 5/10

VO 182

IS 3-4

SP 269

OP 277

K1 Stromboli

$\mathrm{K} 1$ civil protection

K1 emergency management

$\mathrm{K} 1$ volcanic risk

T2 The 2007 Eruption of Stromboli

SN 0377-0273

DO http://dx.doi.org/10.1016/j.jvolgeores.2009.01.022

DS ScienceDirect

UL http://www.sciencedirect.com/science/article/pii/S0377027309000407

OL Unknown(0)

RT Journal Article

SR Print(0)

ID 154

A1 Bird,Deanne K.

A1 Gisladottir,Gudrun

T1 Residents' attitudes and behaviour before and after the 2010 Eyjafjallajokull eruptions-a case study from southern Iceland

JF Bulletin of Volcanology

YR 2012

VO 74

IS 6

SP 1263

$\mathrm{K} 1$ ash flow

$\mathrm{K} 1$ hazard management

K1 outburst

K1 public attitude

$\mathrm{K} 1$ risk perception

K1 social impact

K1 strategic approach

$\mathrm{K} 1$ volcanic ash

K1 volcanic eruption 
K1 vulnerability

AB While the disruption to international air travel caused by the eruption of Iceland's Eyjafjallajo\&die;kull volcano in 2010 has been well documented, the significant social impacts on local residents from ash fall to the south and east of the crater are less well-known. These impacts and attitudes of impacted residents and emergency managers are the foci of our present study. Prior to and during the eruption, officials worked to protect the local population from the glacial outburst floods (jo\&die;kulhlaup) that were of primary concern. The success of these endeavours can in part be attributed to a regional evacuation exercise held in March 2006, an exercise that was carried out with respect to a possible eruption at another volcano, Katla, that is located $25 \mathrm{~km}$ to the east of Eyjafjallajo\&die;kull. Eruptions at either volcano will impact the same communities. Our study here concentrates on A\&acute;/ftaver, a small farming community, located approximately $60 \mathrm{~km}$ east-southeast of Eyjafjallajo\&die;kull and $30 \mathrm{~km}$ southeast of Katla. A\&acute;Iftaver has been the subject of longitudinal studies carried out in 2004, 2006, and 2008; these studies highlighted the difficulties that emergency managers face in developing appropriate response strategies acceptable to vulnerable communities. The 2010 Eyjafjallajo\&die;kull eruptions presented an opportunity to re-assess residents' attitudes and behaviour in relation to volcanic risk management in the wake of their first-hand experiences with volcanic hazards. To achieve this, interviews were conducted with residents and emergency management officials and a questionnaire was distributed to residents. This paper presents the results of this survey and examines changes in attitudes towards volcanic risk management. It was apparent that the experience of ash fall from Eyjafjallajo\&die;kull provided a better perspective of what could be expected from a Katla eruption and that attitudes towards emergency management had evolved accordingly. Importantly, officials' perceptions of risk are now more aligned with those of residents and both recognise the need for more detailed and concise information regarding the impacts of ash fall during and following volcanic eruptions. \&copy; 2012 Springer-Verlag.

PP Tiergartenstrasse 17, Heidelberg, D-69121, Germany

SN 02588900

LA English

LK http://dx.doi.org/10.1007/s00445-012-0595-z

DB Compilation and indexing terms, Copyright 2013 Elsevier Inc.; GEOBASE

OL Unknown(0)

RT Journal Article

SR Print(0)

ID 2321

A1 Bird,Michael

A1 Cowie,Susan

A1 Hawkes,Andrea

A1 Horton,Ben

A1 Macgregor, Colin

A1 Ong, Jin Eong

A1 Hwai,Aileen Tan Shau

A1 Sa,Teh Tiong

A1 Yasin,Zulfigar

T1 Indian Ocean Tsunamis: Environmental and Socio-Economic Impacts in Langkawi, Malaysia JF The Geographical Journal

YR 2007

FD Jun.

VO 173

IS 2

SP 103

OP 117 
$A B$ We report the results of a study of the physical characteristics and socio-economic impacts of the Indian Ocean Tsunami of 26 December 2004 on the tourist island of Langkawi, Malaysia. In comparison with many other locations struck by the tsunami, the immediate physical and socio-economic impacts in Langkawi were relatively minor. A detailed survey of the watermark and ground elevations was undertaken in the worst affected area between Sungei Kuala Teriang and Sungei Kuala Melaka. Here, the tsunami reached a maximum elevation of $4.29 \mathrm{~m}$ as it crossed the coast, with a maximum flow depth of $2.0 \mathrm{~m}$ and a very consistent run-up elevation relative to mean sea level of $300 \pm 10 \mathrm{~cm}$. The tsunami inundated inshore areas for $300 \mathrm{~m}$ and penetrated inland along creeks for 500-1000 m. Structural damage to buildings was confined to within $50-150 \mathrm{~m}$ of the shoreline where about $10 \%$ of the houses were completely destroyed and $60-70 \%$ suffered significant structural damage. Damage was particularly severe in areas where there was no engineered coastal protection, but while coastal revetments did provide enhanced protection for houses at the waterfront, the coastline in the study area appeared to be more heavily impacted than elsewhere in Langkawi because wave energy was focused on the area by offshore breakwaters built to protect the Langkawi port and airport. Emergency response after the tsunami was rapid and efficient but would have been improved if the local police station had not been rendered inoperative by the first wave, and if a mechanism had been in place to ensure that informal advance warnings transmitted between Phuket (Thailand), Langkawi and Penang (Malaysia) by tourist operators could have been more widely disseminated.

PB Wiley on behalf of The Royal Geographical Society (with the Institute of British

Geographers)

SN 00167398

LA English

SF research-article; Copyright (C) 2007 The Royal Geographical Society (with the Institute of British Geographers)

LK http://www.jstor.org/stable/30130642

DS JSTOR

OL Unknown(0)

RT Book, Whole

SR Print(0)

ID 1800

A1 Blackett,P.

A1 Hume, T.

T1 Community involvement in coastal hazard mitigation; some insights into process and pitfalls JF 2007 New Zealand Planning Institute conference

YR 2007

K1 Muriwai Beach

K1 Urenui New Zealand

K1 communities

$\mathrm{K} 1$ geologic hazards

K1 Australasia

$\mathrm{K} 1$ public awareness

$\mathrm{K} 1$ erosion

$\mathrm{K} 1$ shorelines

K1 Bay of Plenty

K1 Mangawhai New Zealand

K1 North Island

$\mathrm{K} 1$ mitigation

K1 Mokau New Zealand

$\mathrm{K} 1$ littoral erosion

K1 New Zealand

K1 22:Environmental geology 
AB Resource management authorities are challenged with managing both the numerous hazards associated with the coastal environment and the people that live work and play in these places. A task which has become more difficult as the coastline is increasingly populated and land values raise, primarily because of the greater risk and vulnerability of homes and infrastructure to natural process. When an event, like coastal erosion occurs, conflict over how to solve the problems are inevitable as a wide range of values and interests clash. This paper examines the role that community groups can play in mitigating coastal hazards, the key factors that lead to groups achieving their goals and the influence that groups have on mitigation policy. Six case studies were investigated with a focus on actual local outcomes, relationships between key stakeholder, especially the community, local government and technical specialists. Although each study is different, some interesting parallels can be drawn about key elements of process, pitfalls and barriers to achieving protection of the natural character of the coastal environment (under section 6 of the Resource Management Act 1991) and maintaining wider community interests. A conceptual model is used to link these and provide a framework for discussion. Of particular importance is the role of power, value of relationship building, resource availability, local authority alignment, and the necessity of good scientific input.

NO Source type: books; Object type: Article; Object type: Book; Object type: Conference Paper; Copyright: GeoRef, Copyright 2012, American Geosciences Institute. Reference includes data supplied by Institute of Geological and Nuclear Sciences Limited (GNS Science), Lower Hutt, New Zealand; CSAUnique: 2009-053070; AccNum: 2009-053070; DocISBN:

0868691135

PB New Zealand Planning Institute, Auckland

PP Auckland, New Zealand (NZL)

SN 0868691135

AN 50424400; 2009-053070

LA English

LK http://search.proquest.com/docview/50424400?accountid=13908

DB GeoRef

DS ProQuest

UL http://smu.worldcat.org/openurlresolver?

genre=book\&isbn=0868691135\&issn=\&title=Community+involvement+in+coastal+hazard +miti gation \%253B+some+insights+into+process+and+pitfalls\&title=Community+involvement+in+co astal+hazard+mitigation $\% 253 \mathrm{~B}+$ some+insights+into+process+and+pitfalls \&volume=\&issue=\& date=2007\&atitle=\&aulast=Blackett\%252c+P\&spage=\&sid=GeoRef\&pid=

OL Unknown(0)

RT Journal Article

SR Print(0)

ID 487

A1 Brouwer,Roy

A1 Akter,Sonia

A1 Brander,Luke

A1 Haque,Enamul

T1 Socioeconomic vulnerability and adaptation to environmental risk: A case study of climate change and flooding in Bangladesh

JF Risk Analysis

YR 2007

VO 27

IS 2

SP 313

K1 coping strategy

$\mathrm{K} 1$ disaster relief

$\mathrm{K} 1$ environmental risk 
K1 flood

K1 poverty

$\mathrm{K} 1$ risk assessment

$\mathrm{K} 1$ socioeconomic conditions

K1 vulnerability

$A B$ In this article we investigate the complex relationship between environmental risk, poverty, and vulnerability in a case study carried out in one of the poorest and most flood-prone countries in the world, focusing on household and community vulnerability and adaptive coping mechanisms. Based upon the steadily growing amount of literature in this field we develop and test our own analytical model. In a large-scale household survey carried out in southeast Bangladesh, we ask almost 700 floodplain residents living without any flood protection along the River Meghna about their flood risk exposure, flood problems, flood damage, and coping mechanisms. Novel in our study is the explicit testing of the effectiveness of adaptive coping strategies to reduce flood damage costs. We show that, households with lower income and less access to productive natural assets face higher exposure to risk of flooding. Disparity in income and asset distribution at community level furthermore tends to be higher at higher risk exposure levels, implying that individually vulnerable households are also collectively more vulnerable. Regarding the identification of coping mechanisms to deal with flood events, we look at both the ex ante household level preparedness for flood events and the ex post availability of community-level support and disaster relief. We find somewhat paradoxically that the people that face the highest risk of flooding are the least well prepared, both in terms of household-level ex ante preparedness and community-level ex post flood relief. \&copy; 2007 Society for Risk Analysis.

SN 02724332

LA English

LK http://dx.doi.org/10.1111/j.1539-6924.2007.00884.x

DB Compilation and indexing terms, Copyright 2013 Elsevier Inc.; GEOBASE

OL Unknown(0)

RT Journal Article

SR Print(0)

ID 658

A1 Buxton, Michael

A1 Haynes, Rachel

A1 Mercer,David

A1 Butt,Andrew

T1 Vulnerability to Bushfire Risk at Melbourne's Urban Fringe: The Failure of Regulatory Land Use Planning

JF Geographical Research

YR 2011

VO 49

IS 1

SP 1

K1 climate change

$\mathrm{K} 1$ flood

$\mathrm{K} 1$ land use planning

K1 metropolitan area

K1 periurban area

K1 population growth

$\mathrm{K} 1$ regulatory framework

AB The 7 February 2009 bushfires in the peri-urban region to the north of metropolitan

Melbourne heralded what many have called an entirely new epoch in terms of weather-related disasters in Australia. A total of 173 people and 2000 properties were destroyed and, as with the 1939 fires in Victoria, a Royal Commission was subsequently instituted to inquire into the 
causes and responses to the fire. The Royal Commission has heard much evidence about alleged failings of fire response, communication and administration. It also considered land use planning issues and the associated regulatory framework. Using the Shire of Murrindindi as a case study, this paper argues that the location of population growth, and associated regulatory failure, are contributory, yet under-researched, factors associated with life and property losses. The adoption of more robust planning tools which incorporate climate change considerations, we argue, is essential to anticipate and minimise the impacts of disastrous natural events such as bushfires. In the latter part of the paper, attention is drawn to a recent Victorian Civil and Administrative Tribunal decision which is groundbreaking in its use of the precautionary principle to prevent dwelling construction in an 'inappropriate' location as well as to some major inconsistencies between planning for flood and bushfire threats. \&copy; 2010 The Authors. Geographical Research \&copy; 2010 Institute of Australian Geographers.

PP 9600 Garsington Road, Oxford, OX4 2XG, United Kingdom

SN 17455863

LA English

LK http://dx.doi.org/10.1111/j.1745-5871.2010.00670.x

DB Compilation and indexing terms, Copyright 2013 Elsevier Inc.; GEOBASE

OL Unknown(0)

RT Journal Article

SR Print(0)

ID 1315

A1 Calgaro,Emma

A1 Lloyd, Kate

T1 Sun, sea, sand and tsunami: examining disaster vulnerability in the tourism community of Khao Lak, Thailand

JF Singapore Journal of Tropical Geography

YR 2008

FD 11

VO 29

IS 3

SP 288

OP 306

K1 TOURISM

K1 TRAVEL

K1 MINERAL aggregates

K1 OCEAN

K1 STAKEHOLDERS

K1 STOCKHOLDERS

K1 CAPITALISTS \& financiers

K1 INDIAN Ocean

K1 THAILAND

$\mathrm{K} 1$ coastal hazards

$\mathrm{K} 1$ place

$\mathrm{K} 1$ relational scale

$\mathrm{K} 1$ sustainable development

K1 vulnerability assessment

AB The impact of the 2004 Indian Ocean tsunami on coastal tourism communities highlights the vulnerability of tourism destinations to external shocks. Based on fieldwork conducted in Thailand in the wake of this disaster, this paper addresses one fundamental question: what sociopolitical and environmental conditions contributed to the vulnerability of the affected tourism community of Khao Lak in the southern Phang Nga Province. We argue that an understanding of the root causes of destination vulnerability is vital not only for the successful implementation of regional recovery plans, but also for building long-term resilience against 
future shocks. In the absence of an appropriate tourism vulnerability framework, this paper analyzes Khao Lak's vulnerability through an innovative theoretical framework comprised of the sustainability vulnerability framework, relational scale and place. The findings reveal that Khao Lak's vulnerability is shaped by 13 interlinked factors. These are the complex outcomes of social norms and developmental and dynamic governance processes driven by the competing agendas and scaled actions of key government and industry stakeholders. The identification and understanding of the drivers of Khao Lak's vulnerability and a strong vulnerability framework have significant implications for the wider tourism community. First, the empirical findings provide tourism communities with a blueprint for understanding the foundations of their vulnerability to external shocks. Second, the tourism vulnerability framework presented here provides destination communities and government stakeholders with an analytical tool through which to analyze their unique sociopolitical conditions. Together, these empirical and theoretical contributions bring us closer to securing sustainable livelihood futures for tourism dependent communities. ABSTRACT FROM AUTHOR]; Copyright of Singapore Journal of Tropical Geography is the property of Wiley-Blackwell and its content may not be copied or emailed to multiple sites or posted to a listserv without the copyright holder's express written permission. However, users may print, download, or email articles for individual use. This abstract may be abridged. No warranty is given about the accuracy of the copy. Users should refer to the original published version of the material for the full abstract. (Copyright applies to all Abstracts.)

NO M3: Article

PB Wiley-Blackwell

SN 01297619

AN 35175949

LK file://C:/Users/s9130263/Documents/Cases/Calgaro_\&_Lloyd_2008.pdf

DO 10.1111/j.1467-9493.2008.00335.x

DS EBSCO

OL Unknown(0)

RT Journal Article

SR Print(0)

ID 2558

A1 Campbell,Donovan

A1 Barker,David

A1 McGregor,Duncan

T1 Dealing with drought: Small farmers and environmental hazards in southern St. Elizabeth, Jamaica

JF Applied Geography

JO Appl.Geogr.

YR 2011

FD 1

VO 31

IS 1

SP 146

OP 158

K1 Drought

K1 Farming

K1 Environmental hazard

K1 Perception

K1 Jamaica

T2 Hazards

SN 0143-6228

DO http://dx.doi.org/10.1016/j.apgeog.2010.03.007

DS ScienceDirect 
UL http://www.sciencedirect.com/science/article/pii/S0143622810000330

OL Unknown(0)

RT Journal Article

SR Print(0)

ID 1440

A1 Carey,Mark

A1 Huggel,Christian

A1 Bury,Jeffrey

A1 Portocarrero,César

A1 Haeberli,Wilfried

T1 An integrated socio-environmental framework for glacier hazard management and climate change adaptation: lessons from Lake 513, Cordillera Blanca, Peru

JF Climatic Change

JO Clim.Change

YR 2012

FD 06

VO 112

IS 3

SP 733

OP 767

K1 GLACIERS

K1 HAZARDS

K1 CLIMATIC changes

K1 GLACIAL lakes

K1 CASE studies

K1 QUALITATIVE research

K1 BLANCA, Cordillera (Peru)

K1 PERU

$\mathrm{AB}$ Glacier hazards threaten societies in mountain regions worldwide. Glacial lake outburst floods (GLOFs) pose risks to exposed and vulnerable populations and can be linked in part to long-term post-Little Ice Age climate change because precariously dammed glacial lakes sometimes formed as glaciers generally retreated after the mid-1800s. This paper provides an interdisciplinary and historical analysis of 40 years of glacier hazard management on Mount Hualcán, at glacial Lake 513, and in the city of Carhuaz in Peru's Cordillera Blanca mountain range. The case study examines attempted hazard zoning, glacial lake evolution and monitoring, and emergency engineering projects to drain Lake 513. It also analyzes the 11 April 2010 Hualcán rock-ice avalanche that triggered a Lake 513 GLOF; we offer both a scientific assessment of the possible role of temperature on slope stability and a GIS spatial analysis of human impacts. Qualitative historical analysis of glacier hazard management since 1970 allows us to identify and explain why certain actions and policies to reduce risk were implemented or omitted. We extrapolate these case-specific variables to generate a broader socioenvironmental framework identifying factors that can facilitate or impede disaster risk reduction and climate change adaptation. Facilitating factors are technical capacity, disaster events with visible hazards, institutional support, committed individuals, and international involvement. Impediments include divergent risk perceptions, imposed government policies, institutional instability, knowledge disparities, and invisible hazards. This framework emerges from an empirical analysis of a coupled social-ecological system and offers a holistic approach for integrating disaster risk reduction and climate change adaptation. ABSTRACT FROM AUTHOR]; Copyright of Climatic Change is the property of Springer Science \& Business Media B.V. and its content may not be copied or emailed to multiple sites or posted to a listserv without the copyright holder's express written permission. However, users may print, download, or email articles for individual use. This abstract may be abridged. No warranty is 
given about the accuracy of the copy. Users should refer to the original published version of the material for the full abstract. (Copyright applies to all Abstracts.)

NO M3: Article

SN 01650009

AN 75062885

LK http://library.smu.ca:2048/login?http://search.ebscohost.com/login.aspx?

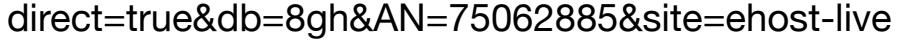

DO 10.1007/s10584-011-0249-8

DS EBSCO

OL Unknown(0)

RT Journal Article

SR Print(0)

ID 57

A1 Cashman,A. C.

T1 Case study of institutional and social responses to flooding: Reforming for resilience?

JF Journal of Flood Risk Management

YR 2011

VO 4

IS 1

SP 33

$\mathrm{K} 1$ ecosystem resilience

K1 flooding

$\mathrm{K} 1$ investment location

$\mathrm{K} 1$ risk assessment

K1 social structure

$\mathrm{K} 1$ stakeholder

AB Flood management has until recently emphasised investment and trust in constructed solutions that rely mainly on structural robustness. However, there has been a shift in the attitudes and policies towards flood risk management that emphasises a systems approach in which robustness and resilience now have an equal part to play. Agencies that have responsibility for flood management are now looking at the role of communities and individuals, ideas of accommodation and living with floods and placing an emphasis on building resilience among stakeholders as a coping strategy within the management of flood risks. The paper uses the case study of Bradford to explore what might be meant by resilience and how the actions taken by Bradford City Council have contributed towards building social resilience with respect to flood risk management. \&copy; 2011 The Authors. Journal of Flood Risk

Management \&copy; 2011 The Chartered Institution of Water and Environmental Management. PP 350 Main Street, Malden, MA 02148, United States

SN 1753318X

LA English

LK http://dx.doi.org/10.1111/j.1753-318X.2010.01087.x

DB Compilation and indexing terms, Copyright 2013 Elsevier Inc.; GEOBASE

OL Unknown(0)

RT Journal Article

SR Print(0)

ID 3190

A1 Cashman,A. C.

T1 Institutional Responses to Urban Flooding: Case Studies from Bradford and Glasgow

JF 11th International Conference on Urban Drainage, Edinburgh, Scotland, UK, 2008

YR 2008

SP 1

LK file://C:/Users/s9130263/Documents/Cases/Cashman_2008.pdf 
OL Unknown(0)

RT Journal Article

SR Print(0)

ID 1953

A1 Chamlee-Wright,Emily

A1 Storr,Virgil Henry

T1 Expectations of government's response to disaster

JF Public Choice

JO Public Choice

YR 2010

FD July

VO 144

IS $1 / 2$

SP 253

OP 274

AB Citizens' expectations about what government is capable of doing and what policies government officials intend to pursue can influence their decisions. After a disaster, for instance, expectations of government's intent and capacity to assist in the rebuilding process will influence the rebuilding strategies that affected citizens adopt. This article develops a typology that categorizes citizens' expectations of government response to disaster. We then deploy this typology to identify expectation patterns among residents and other private actors in New Orleans' Ninth Ward communities who have returned following Katrina and explain how these expectations shape their preferred rebuilding strategy.

PB Springer

SN 00485829

LA English

SF research-article; Copyright (C) 2010 Springer

LK http://www.jstor.org/stable/40661059

DS JSTOR

OL Unknown(0)

RT Journal Article

SR Print(0)

ID 419

A1 Cheong,So-Min

T1 Korean fishing communities in transition: limitations of community-based resource management

JF Environment \& Planning A

YR 2005

FD 07

VO 37

IS 7

SP 1277

OP 1290

K1 FISHING

K1 FISHING villages

K1 INFORMATION resources management

K1 RESOURCE management

K1 TOURISM

K1 KOREA

K1 Administration and Economy

AB This paper addresses limitations of community-based resource management by examining Korean fishing communities making the transition into tourism. It challenges local-centered 
views of resource management implemented through a homogeneous, cooperative, and selfreliant community. Local communities more often than not consist of diverse groups, demonstrate internal political dynamics, and need external resources in times of crisis. Utilizing three case studies of depressed Korean fishing communities, the author emphasizes the significance of external linkages, and concludes that existing community-based resource management is not adequate to the task of transition. ABSTRACT FROM AUTHOR]; Copyright of Environment \& Planning A is the property of Pion Ltd. and its content may not be copied or emailed to multiple sites or posted to a listserv without the copyright holder's express written permission. However, users may print, download, or email articles for individual use. This abstract may be abridged. No warranty is given about the accuracy of the copy. Users should refer to the original published version of the material for the full abstract. (Copyright applies to all Abstracts.)

NO M3: Article

SN 0308518X

AN 17808306

LK http://library.smu.ca:2048/login?http://search.ebscohost.com/login.aspx?

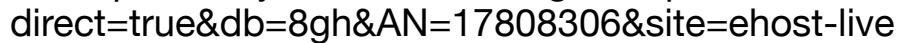

DO 10.1068/a37139

DS EBSCO

OL Unknown(0)

RT Journal Article

SR Print(0)

ID 2434

A1 Chhotray,Vasudha

A1 Few,Roger

T1 Post-disaster recovery and ongoing vulnerability: Ten years after the super-cyclone of 1999 in Orissa, India

JF Global Environmental Change

JO Global Environ.Change

YR 2012

FD 8

VO 22

IS 3

SP 695

OP 702

K1 Recovery

K1 Vulnerability

K1 Hazard

K1 Disaster

K1 Chronic

K1 Orissa

T2 Global transformations, social metabolism and the dynamics of socio-environmental

conflicts

SN 0959-3780

DO http://dx.doi.org/10.1016/j.gloenvcha.2012.05.001

DS ScienceDirect

UL http://www.sciencedirect.com/science/article/pii/S0959378012000556

OL Unknown(0)

RT Journal Article

SR Print(0)

ID 2694

A1 Chidanti-Malunga,J. 
T1 Adaptive strategies to climate change in Southern Malawi

JF Physics and Chemistry of the Earth, Parts A/B/C

YR 2011

VO 36

IS 14-15

SP 1043

OP 1046

K1 Droughts

K1 Floods

$\mathrm{K} 1$ Indigenous elements

K1 Irrigation

K1 Residual moisture

$\mathrm{K} 1$ Wetland

T2 11th WaterNet/WARFSA/GWP-SA Symposium: IWRM for National and Regional Integration through Science, Policy and Practice

SN 1474-7065

DO http://dx.doi.org/10.1016/j.pce.2011.08.012

DS ScienceDirect

UL http://www.sciencedirect.com/science/article/pii/S1474706511002142

OL Unknown(0)

RT Journal Article

SR Print(0)

ID 165

A1 Chung,J.

T1 Fiji, land of tropical cyclones and hurricanes: a case study of agricultural rehabilitation.

JF Disasters

JO Disasters

YR 1987

VO 11

IS 1

SP 40

$\mathrm{K} 1$ agriculture

$\mathrm{K} 1$ crops

$\mathrm{K} 1$ cyclones

K1 Fiji

K1 livestock

$\mathrm{K} 1$ mitigation

K1 Pacific region

K1 rehabilitation

K1 vulnerability

AB Tropical cyclones and hurricanes have a severe impact on the social and economic activities of affected communities. During the last decade, the frequency of natural disasters and their adverse impact on the economic and social development of small nations like Fiji, has aroused awareness that relief efforts must go beyond immediate 'mopping up' operations to those which contribute to attaining longer term benefits through reconstruction and rehabilitation. Outlines the 1985 agricultural rehabilitation program and discusses related issues and problems.-Author

SN 03613666

LA English

DB Compilation and indexing terms, Copyright 2013 Elsevier Inc.; GEOBASE

OL Unknown(0)

RT Journal Article 
SR Print(0)

ID 2023

A1 Cleary,W. J.

A1 Willson,K. T.

A1 Jackson,C. W.

T1 Shoreline Restoration in High Hazard Zones: Southeastern North Carolina, USA

JF Journal of Coastal Research

JO J.Coast.Res.

YR 2006

FD Winter

IS , Special Issue No. 39. Proceedings of the 8th International Coastal Symposium (ICS 2004),

Vol. II

SP 884

OP 889

AB A number of high-risk segments along southeastern North Carolina have partially recovered from the impacts of the hurricanes in the late 1990s; however many severely impacted areas are still at risk. A primary management concern related to these high hazard areas, is the controversial issue of beach nourishment. More than $80 \%$ of the $180 \mathrm{~km}$ long shoreline between Cape Lookout and Cape Fear is extensively developed. All communities that comprise this reach are involved in some form of replenishment activities ranging from feasibility studies to major nourishment projects. Aside from the financial aspects of nourishment, many communities are concerned with the availability of sand resources for nourishment programs. Long-term chronic erosion and the lack of significant recovery have prompted a re-examination of offshore areas for sand resources for erosion and storm damage reduction projects. Many of these sediment-starved reaches have little storm protection in place and have a marginal potential for locating suitable beach fill resources for nourishment purposes. Consequently, major sections of some high hazard reaches will have to be abandoned, as relocation is not an option. The study focuses on Topsail Island, a $40 \mathrm{~km}$ long transgressive barrier, as an exemplary barrier setting where three communities with different environmental and erosion histories are confronted with identifying large volumes of sand to meet their nourishment needs.

PB Coastal Education \& Research Foundation, Inc.

SN 07490208

LA English

SF research-article; Copyright (C) 2006 Coastal Education \& Research Foundation, Inc.

LK http://www.jstor.org/stable/25741704

DS JSTOR

OL Unknown(0)

RT Journal Article

SR Print(0)

ID 1646

A1 Colten,Craig E.

A1 Giancarlo,Alexandra

T1 Losing Resilience on the Gulf Coast: Hurricanes and Social Memory

JF Environment

YR 2011

FD 06/24

VO 53

IS 4

SP 6

OP 19

K1 HURRICANES

K1 HURRICANE protection 
K1 HAZARD mitigation

K1 EMERGENCY management

K1 COLLECTIVE memory

K1 RESILIENCE (Personality trait)

K1 HURRICANE Betsy, 1965

K1 HURRICANE Camille, 1969

K1 LAW \& legislation

K1 PREPAREDNESS

K1 GULF States

AB The article discusses the relationship between hurricanes in the U.S. Gulf Coast and social memory. The authors argue that short-term adaptations following Hurricane Betsy in September 1965 and Hurricane Camille in August 1969 in New Orleans, Louisiana and the Mississippi coast, respectively, offered residents a degree of hurricane resistance, but the longterm erosion of collective memory of the events was a contributing factor in the loss of community resilience. The authors explore aspects of social memory during the interval between hurricanes in the Gulf Coast and how an erosion in the urgency and immediacy of preparedness contributed to the loss of resiliency over the course of several decades, specifically post-hurricane policies and practices.

NO M3: Article

SN 00139157

AN 79469660

LK http://library.smu.ca:2048/login?http://search.ebscohost.com/login.aspx?

direct $=$ true $\& \mathrm{db}=8 \mathrm{gh} \& \mathrm{AN}=79469660 \&$ site=ehost-live

DO 10.1080/00139157.2011.588548

DS EBSCO

OL Unknown(0)

RT Journal Article

SR Print(0)

ID 1008

A1 Colten,Craig E.

A1 Kates,Robert W.

A1 Laska,Shirley B.

T1 Three Years after Katrina: Lessons for Community Resilience

JF Environment

YR 2008

FD 09

VO 50

IS 5

SP 36

OP 47

K1 RESILIENCE (Personality trait)

K1 NATURAL disasters

K1 HURRICANE Katrina, 2005 -- Environmental aspects

K1 HURRICANE Katrina, 2005 -- Economic aspects

K1 COMMUNITY change

K1 PSYCHOLOGICAL aspects

K1 LOUISIANA

K1 NEW Orleans (La.)

K1 UNITED States

AB The article discusses the U.S. city of New Orleans, Louisiana and the resiliency of its citizens and community. The example given is the devastation by Hurricane Katrina in 2005. Katrina overwhelmed the levees, flooded the city, and caused nearly 1,300 deaths. The damages were estimated in the tens of billions of dollars. In 2008 levees have been partially 
rebuilt, the pre-storm population is increasing, and tourism has been restored. A discussion of how resilience enables communities to rebound after natural disasters, the elements of resilience, and an assessment of the resilience in New Orleans' community are presented.

NO M3: Article

PB Taylor \& Francis Ltd

SN 00139157

AN 34054389

LK http://library.smu.ca:2048/login?http://search.ebscohost.com/login.aspx?

direct=true\&db=aph\&AN=34054389\&site=ehost-live

DS EBSCO

OL Unknown(0)

RT Journal Article

SR Print(0)

ID 1999

A1 Das,Bidhan Kanti

T1 Flood Disasters and Forest Villagers in Sub-Himalayan Bengal

JF Economic and Political Weekly

YR 2009

FD Jan. 24 - 30

VO 44

IS 4

SP 71

OP 76

AB Conservation policies to protect wildlife and biodiversity ignore the basic survival needs and imperatives of local people. This article aims to show how conservation policies trigger floods in protected areas, especially those located in the foothills of the Himalayan mountain ranges, leading to huge damage to plantations and habitats as well as settlements of the local people. It also explores what forest villagers do when the whole village is destroyed by a natural disaster and the socio-economic consequences in the post-displacement period.

PB Economic and Political Weekly

SN 00129976

LA English

SF research-article; Copyright (c) 2009 Economic and Political Weekly

LK http://www.jstor.org/stable/40278835

DS JSTOR

OL Unknown(0)

RT Journal Article

SR Print(0)

ID 633

A1 Dash, Nicole

A1 Morrow,Betty Hearn

A1 Mainster,Juanita

A1 Cunningham, Lilia

T1 Lasting effects of Hurricane Andrew on a working-class community JF Natural Hazards Review

JO Nat.Hazards Rev.

YR 2007

VO 8

IS 1

SP 13

K1 community development

$\mathrm{K} 1$ damage 
K1 environmental impact

$\mathrm{K} 1$ hazard assessment

K1 landscape change

K1 natural hazard

K1 storm

AB Ten years after Hurricane Andrew, researchers returned to a multiethnic working-class community of homeowners first studied one year after the storm to investigate long-term impact on the community and its residents. Using both qualitative and quantitative data, this case study documents the recovery struggles of modest-income families who had tenuously achieved the American dream of home ownership. While most of the impacted region has recovered, this work highlights deep-seated continuing impacts on many households, as well as changes in the social landscape of the community. In 1992, Hurricane Andrew caused extensive damage to the housing, schools, and community infrastructure of South Miami Heights, Fla., and the first set of interviews (one year after the storm) revealed extensive problems, unrepaired homes, and suffering families. Ten years later a second round of indepth, face-to-face interviews was completed with 32 of the same households, as well as with 10 key community informants to explore the circumstances and recovery level of homes, households, and the community at large. This case study is one of the few truly long-term examinations of a community after a disaster. \&copy; 2007 ASCE.

SN 15276988

LA English

LK http://dx.doi.org/10.1061/(ASCE)1527-6988(2007)8:1(13)

DB Compilation and indexing terms, Copyright 2013 Elsevier Inc.; GEOBASE

OL Unknown(0)

RT Journal Article

SR Print(0)

ID 3160

A1 De Bélizal,Édouard

A1 Lavigne,Franck

A1 Gaillard,J. C.

A1 Grancher,Delphine

A1 Pratomo,Indyo

A1 Komorowski,Jean-Christophe

T1 The 2007 eruption of Kelut volcano (East Java, Indonesia): Phenomenology, crisis management and social response

JF Geomorphology

JO Geomorphology

YR 2012

FD $1 / 1$

VO 136

IS 1

SP 165

OP 175

$\mathrm{K} 1$ Crisis management

K1 Human vulnerability

K1 Eruption

K1 Kelut volcano

K1 Indonesia

T2 Volcano Geomorphology: landforms, processes and hazards

SN 0169-555X

DO http://dx.doi.org/10.1016/j.geomorph.2011.06.015

DS ScienceDirect

UL http://www.sciencedirect.com/science/article/pii/S0169555X11003102 
OL Unknown(0)

RT Journal Article

SR Print(0)

ID 48

A1 Dei,G. J. S.

T1 A Ghanaian town revisited: changes and continuities in local adaptive strategies

JF African Affairs

YR 1992

VO 91

IS 362

SP 95

K1 adaptive strategy

K1 community solidarity

K1 coping strategy

K1 developing country

$\mathrm{K} 1$ development process

K1 drought

$\mathrm{K} 1$ economic recession

$\mathrm{K} 1$ indigenous knowledge

K1 local economy

K1 rural area

K1 rural development

AB In 1989, I conducted fieldwork in two rural communities, the towns of Ayirebi and Asokore, in southeastern Ghana. The work in Ayirebi was a follow-up to a 1982 and 1983 research study which had examined the adaptive responses of the local peasant farmers to a crisis in the national economy. The primary focus of the later study was to ascertain and examine the degree and extent to which coping strategies had been sustained long after the drought and economic recession of the early 1980s, and to document how the indigenous people had used their own creativity and resourcefulness to satisfy basic needs. The study focussed on 450 randomly selected households, representing over a quarter of the current Ayirebi households. This case study highlights the significance of the indigenous knowledge base of rural peoples and the essence of community solidarity and local participation in shaping policies affecting rural living conditions. As the current harsh economic conditions persist, the autonomy of rural peoples both in terms of an increasing capacity to identify, analyse and solve their own problems, and to have control over their own resources become extremely important in any rural development process. -from Author

SN 00019909

LA English

DB Compilation and indexing terms, Copyright 2013 Elsevier Inc.; GEOBASE

OL Unknown(0)

RT Journal Article

SR Print(0)

ID 2516

A1 Denhart,Hazel

T1 Deconstructing disaster: Psycho-social impact of building deconstruction in Post-Katrina New Orleans

JF Cities

YR 2009

FD 8

VO 26

IS 4

SP 195 
OP 201

K1 Deconstruction

K1 Demolition

K1 Disaster recovery

K1 Qualitative research

K1 Mercy Corps

SN 0264-2751

DO http://dx.doi.org/10.1016/j.cities.2009.04.003

DS ScienceDirect

UL http://www.sciencedirect.com/science/article/pii/S0264275109000572

OL Unknown(0)

RT Journal Article

SR Print(0)

ID 179

A1 Doberstein,Brent

T1 Post-disaster assessment of hazard mitigation for small and medium-magnitude debris flow disasters in Bali, Indonesia and Jimani, Dominican Republic

JF Natural Hazards

JO Nat.Hazards

YR 2009

VO 50

IS 2

SP 361

$\mathrm{K} 1$ adaptive management

K1 debris flow

$\mathrm{K} 1$ disaster management

K1 local government

K1 nongovernmental organization

$A B$ This article explores whether past exposure to debris flow disasters with a human dimension (e.g. caused in part by deforestation) results in adaptive hazard mitigation and improved environmental and resource management practices in affected areas. When guiding hazard mitigation practice, the 'adaptive hazard mitigation' approach views mitigation as a multi-dimensional experiment, with the associated need for post-experiment monitoring, evaluation, learning and adjustment, and attention paid to multiple scales (Bogardi 2004). This article explores how the concept of 'adaptive hazard mitigation' has emerged, linking this 'adaptive management' used increasingly in resource and environmental management. Two case studies of disasters linked to human-induced environmental change are examined, and the mitigation responses of local communities, NGOs and Government agencies are documented. Data sources include secondary data (journal articles, web-based disaster reports and grey literature) on each disaster, key informant interviews $(n=8)$ and direct observation over the 2005-2006 period of post-disaster mitigation actions implemented after each disaster. The research indicates that in both case studies, a limited range of hazard mitigation actions was employed, including both structural and non-structural approaches. However, the research also found that causal factors involving human-induced environmental change (e.g. deforestation) were not addressed, and overall, the hazard mitigation strategies adopted lacked monitoring, learning and adjustment. In both case studies, responses to disaster were judged to be examples of 'trial and error' adaptation, rather than either 'passive' or 'active' adaptation. \&copy; Springer Science+Business Media B.V. 2009.

SN 0921030X

LA English

LK file:///C:/Users/s9130263/Documents/Cases/Doberstein_2009.pdf

DB Compilation and indexing terms, Copyright 2013 Elsevier Inc.; GEOBASE

OL Unknown(0) 
RT Journal Article

SR Print(0)

ID 813

A1 Dodman,David

A1 Mitlin,Diana

A1 Co,Jason Rayos

T1 Victims to victors, disasters to opportunities: Community-driven responses to climate change in the Philippines

JF International Development Planning Review

YR 2010

FD 01/01

VO 32

IS 1

SP 1

OP 26

NO General Legislative \& Exec., International Relations

PB Liverpool University Press - Turpin Distribut

SN 1474-6743; 1478-3401

LK https://www.swetswise.com/swoc-web/link/access_db?

issn $=1478-3401 \& \mathrm{vol}=00032 \&$ iss $=00001 \&$ page $=1 \&$ year $=2010$

OL Unknown(0)

RT Journal Article

SR Print(0)

ID 1475

A1 Eakin, Hallie

A1 Benessaiah,Karina

A1 Barrera,Juan

A1 Cruz-Bello,Gustavo

A1 Morales, Helda

T1 Livelihoods and landscapes at the threshold of change: disaster and resilience in a Chiapas coffee community

JF Regional Environmental Change

YR 2012

FD 09

VO 12

IS 3

SP 475

OP 488

K1 FARMS

K1 CASE studies

K1 HURRICANE Stan, 2005

K1 HOUSEHOLD surveys

K1 CHIAPAS (Mexico)

K1 MEXICO

K1 Adaptation

K1 Coffee

$\mathrm{K} 1$ Disaster

K1 Maize

K1 Resilience

K1 Vulnerability

AB In 2005, torrential rains associated with Hurricane Stan devastated farm systems in southern Mexico. We present a case study on the impacts of and responses to Hurricane Stan 
by coffee households in three communities in the highlands of Chiapas, Mexico, with the objective of illuminating the linkages between household vulnerability and resilience. We analyze data from 64 household surveys in a cluster analysis to link household impacts experienced to post-Stan adaptive responses and relate these results with landscape-level land-cover changes. The degree of livelihood change was most significant for land-constrained households whose specialization in coffee led to high exposure and sensitivity to Stan and little adaptive capacity. Across the sample, the role of coffee in livelihood strategies declined, as households sought land to secure subsistence needs and diversified economically after Stan. Nevertheless, livelihoods and landscape outcomes were not closely coupled, at least at the temporal and spatial scale of our analysis: We found no evidence of land-use change associated with farmers' coping strategies. While households held strong attitudes regarding effective resource management for risk reduction, this knowledge does not necessarily translate into capacities to manage resilience at broader scales. We argue that policy interventions are needed to help materialize local strategies and knowledge on risk management, not only to allow individual survival but also to enhance resilience at local, community and landscape scales. ABSTRACT FROM AUTHOR]; Copyright of Regional Environmental Change is the property of Springer Science \& Business Media B.V. and its content may not be copied or emailed to multiple sites or posted to a listserv without the copyright holder's express written permission. However, users may print, download, or email articles for individual use. This abstract may be abridged. No warranty is given about the accuracy of the copy. Users should refer to the original published version of the material for the full abstract. (Copyright applies to all Abstracts.)

NO M3: Article

SN 14363798

AN 78437435

LK http://library.smu.ca:2048/login?http://search.ebscohost.com/login.aspx?

direct $=$ true $\& \mathrm{db}=8 \mathrm{gh} \& A \mathrm{~N}=78437435 \&$ site=ehost-live

DO 10.1007/s10113-011-0263-4

DS EBSCO

OL Unknown(0)

RT Journal Article

SR Print(0)

ID 1740

A1 Ehsan-ul-Haq

T1 Community Response to Climatic Hazards in Northern Pakistan

JF Mountain Research and Development

YR 2007

FD Nov 2007

VO 27

IS 4

SP 308

OP 312

K1 Earth Sciences

K1 1B

K1 Sustainability Science Abstracts

K1 Earthquakes

K1 Pakistan

K1 Climate

K1 Disasters

K1 outbreaks

$\mathrm{K} 1$ local communities

K1 Landslides

K1 Mountains 
K1 Hazards

K1 households

K1 winter

K1 Floods

K1 Seismic activity

K1 summer

K1 Research programs

K1 M3 1010:Issues in Sustainable Development

$A B$ Chitral is a landlocked and mountainous region of northern Pakistan located in the Hindu Kush mountains, with a total population of around 400,000 in 50,000 households. The inhabitants of Chitral face a variety of problems associated with climatic hazards throughout the year, such as heavy snowfall in winter, flash floods in summer, glacial outbursts, soil erosion, landslides, occasional earthquakes, and subsequent outbreaks of disease. In such a fragile environment, the collective action of local communities through grassroots institutionsVillage and Women's Organizations (V/WOs) and the second generation of these institutions, Local Support Organizations (LSOs)-has been instrumental in effectively tackling these problems. LSOs play the role of a laboratory for engagement by civil society and developing institutional mechanisms to address development challenges, including natural hazards and disasters in the area.

NO Source type: scholarlyjournals; Object type: Article; Object type: Feature; CSAUnique: OBMD-0008757353; AccNum: 8702550; DOI: 10.1659/mrd.0947; ISSN: 0276-4741; Peer

Reviewed: true

PB International Mountain Society

PP Japan

SN 0276-4741

AN 289549146; 8702550

LA English

LK file://C:/Users/s9130263/Documents/Cases/Ehsan-ul-Haq_2007.pdf;

DO http://dx.doi.org/10.1659/mrd.0947

DB GeoRef

DS ProQuest

UL http://QN8PM6GK2Q.search.serialssolutions.com/directLink?

\&atitle=Community+Response+to+Climatic+Hazards+in+Northern+Pakistan\&author=\&issn=02

764741\&title=Mountain+Research+and+Development\&volume=27\&issue=4\&date=2007-11-01

\&spage=308\&id=doi:10.1659\%252Fmrd.0947\&sid=ProQ_ss\&genre=article; http://dx.doi.org/

$10.1659 / \mathrm{mrd} .0947$

OL Unknown(0)

RT Journal Article

SR Print(0)

ID 2651

A1 Elnashai,Amr S.

A1 Gencturk,Bora

A1 Kwon,Oh-Sung

A1 Hashash, Youssef M. A.

A1 Kim,Sung Jig

A1 Jeong,Seong-Hoon

A1 Dukes, Jazalyn

T1 The Maule (Chile) earthquake of February 27, 2010: Development of hazard, site specific ground motions and back-analysis of structures

JF Soil Dynamics and Earthquake Engineering

JO Soil Dyn.Earthquake Eng.

YR 2012

FD 11 
VO 42

IS 0

SP 229

OP 245

SN 0267-7261

DO http://dx.doi.org/10.1016/j.soildyn.2012.06.010

DS ScienceDirect

UL http://www.sciencedirect.com/science/article/pii/S0267726112001376

OL Unknown(0)

RT Journal Article

SR Print(0)

ID 1061

A1 Eriksen,Siri

A1 Selboe,Elin

T1 The social organisation of adaptation to climate variability and global change: The case of a mountain farming community in Norway

JF Applied Geography

JO Appl.Geogr.

YR 2012

FD 04

VO 33

SP 159

OP 167

K1 SOCIAL structure

K1 SOCIAL adjustment

K1 CLIMATIC changes

K1 GLOBAL environmental change

K1 HILL farming

K1 COMMUNITIES

K1 NORWAY

AB Abstract: Local strategies to manage climate variability are key to adapting to climate change in the long term. We investigate how local adaptive strategies are socially organised through a study of Øystre Slidre, a Norwegian mountain farming community operating close to the climatic margins. Farmers actively use informal social relations in accessing equipment and labour in order to secure production and quality of life. The importance of such relations in managing climate variability persists even with a dramatic shift towards larger scale production, increasing formalisation and economic diversification. Despite social innovations and adaptations such as the re-forming of social relationships and institutions, the concurrent reduction in the number of people involved in farming may be putting the flexibility of social networks and practices of collaboration under pressure, potentially undermining adaptive capacity to climate change. Future research and policy need to focus on ensuring social innovation in the social organisation of adaptation. Copyright \&y\& Elsevier]; Copyright of Applied Geography is the property of Pergamon Press - An Imprint of Elsevier Science and its content may not be copied or emailed to multiple sites or posted to a listserv without the copyright holder's express written permission. However, users may print, download, or email articles for individual use. This abstract may be abridged. No warranty is given about the accuracy of the copy. Users should refer to the original published version of the material for the full abstract. (Copyright applies to all Abstracts.)

NO M3: Article

SN 01436228

AN 67700851

LK http://library.smu.ca:2048/login?http://search.ebscohost.com/login.aspx?

direct $=$ true $\& d b=a p h \& A N=67700851 \&$ site $=$ ehost-live 
DO 10.1016/j.apgeog.2011.10.003

DS EBSCO

OL Unknown(0)

RT Journal Article

SR Print(0)

ID 2622

A1 Esteban,M.

A1 Tsimopoulou,V.

A1 Mikami,T.

A1 Yun,N. Y.

A1 Suppasri,A.

A1 Shibayama,T.

T1 Recent tsunamis events and preparedness: Development of tsunami awareness in Indonesia, Chile and Japan

JF International Journal of Disaster Risk Reduction

YR 2013

FD 9

VO 5

IS 0

SP 84

OP 97

K1 Tsunami

K1 Counter-measures

K1 Awareness

K1 Banda Aceh

K1 Indonesia

K1 Mentawai

K1 Tohoku

K1 Chile

SN 2212-4209

DO http://dx.doi.org/10.1016/j.ijdrr.2013.07.002

DS ScienceDirect

UL http://www.sciencedirect.com/science/article/pii/S221242091300037X

OL Unknown(0)

RT Journal Article

SR Print(0)

ID 2656

A1 Esteban,Miguel

A1 Tsimopoulou,Vana

A1 Shibayama,Tomoya

A1 Mikami,Takahito

A1 Ohira,Koichiro

T1 Analysis of Tsunami Culture in Countries Affected by Recent Tsunamis JF Procedia Environmental Sciences

YR 2013

VO 17

IS 0

SP 693

OP 702

$\mathrm{K} 1$ tsunami culture

K1 multi-layer safety

K1 sustainability of coastal defences 
T2 The 3rd International Conference on Sustainable Future for Human Security, SUSTAIN 2012, 3-5 November 2012, Clock Tower Centennial Hall, Kyoto University, JAPAN

SN 1878-0296

DO http://dx.doi.org/10.1016/j.proenv.2013.02.086

DS ScienceDirect

UL http://www.sciencedirect.com/science/article/pii/S1878029613000881

OL Unknown(0)

RT Journal Article

SR Print(0)

ID 2604

A1 Farida,Anis

T1 Reconstructing Social Identity for Sustainable Future of Lumpur Lapindo Victims JF Procedia Environmental Sciences

YR 2014

VO 20

IS 0

SP 468

OP 476

K1 social identity

K1 solidarity

K1 collective action

$\mathrm{K} 1$ Lapindo mudflow victims

T2 The 4th International Conference on Sustainable Future for Human Security SUSTAIN 2013

SN 1878-0296

DO http://dx.doi.org/10.1016/j.proenv.2014.03.059

DS ScienceDirect

UL http://www.sciencedirect.com/science/article/pii/S1878029614000607

OL Unknown(0)

RT Journal Article

SR Print(0)

ID 2416

A1 Ferdinand,Idelia

A1 O'Brien,Geoff

A1 O'Keefe,Phil

A1 Jayawickrama,Janaka

T1 The double bind of poverty and community disaster risk reduction: A case study from the Caribbean

JF International Journal of Disaster Risk Reduction

YR 2012

FD 12

VO 2

IS 0

SP 84

OP 94

K1 Community

K1 Disaster risk reduction

K1 Vulnerability

K1 Resilience

K1 Caribbean

SN 2212-4209

DO http://dx.doi.org/10.1016/j.ijdrr.2012.09.003

DS ScienceDirect 
UL http://www.sciencedirect.com/science/article/pii/S2212420912000180

OL Unknown(0)

RT Generic

SR Print(0)

ID 420

A1 Finan,Timothy J.

A1 Nelson,Donald R.

T1 Making rain, making roads, making do: public and private adaptations to drought in Ceará, Northeast Brazil

JF Climate Research

YR 2001

FD 12/04

VO 19

IS 2

SP 97

K1 CLIMATIC changes

K1 WEATHER forecasting

K1 DROUGHTS

K1 BRAZIL

K1 CEARA (Brazil : State)

AB Presents a case study concerning the public and private adaptations to climate variability in Ceará State, Northeast Brazil. Vulnerability of the region to various climatic changes; Role of seasonal forecasting in mitigating climatic crises; Implications for an effective drought planning. NO TY: CASE; M3: Case Study

SN 0936577X

AN 7517638

LK http://library.smu.ca:2048/login?http://search.ebscohost.com/login.aspx?

direct $=$ true $\& \mathrm{db}=8 \mathrm{gh} \& \mathrm{AN}=7517638 \&$ site $=$ ehost-live

DS EBSCO

OL Unknown(0)

RT Journal Article

SR Print(0)

ID 2805

A1 Forster,J.

A1 Lake,I. R.

A1 Watkinson,A. R.

A1 Gill,J. A.

T1 Marine dependent livelihoods and resilience to environmental change: A case study of Anguilla

JF Marine Policy

JO Mar.Policy

YR 2014

FD 3

VO 45

IS 0

SP 204

OP 212

K1 Marine livelihoods

K1 Resilience

K1 Vulnerability

$\mathrm{K} 1$ Environmental change

$\mathrm{K} 1$ Marine resource-use 
K1 Caribbean

SN 0308-597X

DO http://dx.doi.org/10.1016/j.marpol.2013.10.017

DS ScienceDirect

UL http://www.sciencedirect.com/science/article/pii/S0308597X1300242X

OL Unknown(0)

RT Journal Article

SR Print(0)

ID 174

A1 Frew,Peter

T1 Adapting to coastal change in north Norfolk, UK

JF Proceedings of the Institution of Civil Engineers: Maritime Engineering

YR 2012

VO 165

IS 3

SP 131

$\mathrm{K} 1$ adaptive management

$\mathrm{K} 1$ coastal engineering

K1 coastal erosion

K1 coastal protection

$\mathrm{K} 1$ coastal zone management

K1 flooding

$\mathrm{K} 1$ local government

K1 sustainability

AB Over the past 200 years society's response to coastal flooding or erosion has been to provide defences to combat or eliminate that threat. A combination of economic pressures, a better understanding of coastal processes and of the impact of those defences on these processes has led to the development of new approaches to coastal management. This paper will show how, by linking planning policies to various types of intervention, a workable, sustainable and equitable approach can be achieved. The need to work closely with communities is emphasised with examples and case studies. Development in zones at risk should be restricted, but equally development should be permitted, perhaps by exception, in other areas to ensure the continuing viability of coastal communities. While the headline issues are around the loss of homes, a part of this process is to ensure that community assets, lost or threatened by coastal change, are also replaced or relocated. The UK's North Norfolk District Council was the recipient of a \&pound;3 million grant from the government's coastal change fund to trial a number of different approaches that can be made, working closely with partners and the coastal communities affected. The paper will describe the various projects (e.g. relocating a village hall, removing derelict defences, acquiring and replacing housing, supporting businesses), programme governance, communications, discuss the problems encountered, how they were addressed and report on the undoubted success of many of the measures that were trialled.

PP 1 Heron Quay, London, E14 4JD, United Kingdom

SN 17417597

LA English

LK http://dx.doi.org/10.1680/maen.2011.23

DB Compilation and indexing terms, Copyright 2013 Elsevier Inc.; GEOBASE

OL Unknown(0)

RT Journal Article

SR Print(0)

ID 1654

A1 Fussell,Elizabeth 
A1 Sastry,Narayan

A1 VanLandingham,Mark

T1 Race, socioeconomic status, and return migration to New Orleans after Hurricane Katrina JF Population \& Environment

YR 2010

FD 01

VO 31

IS 1-3

SP 20

OP 42

K1 HURRICANE Katrina, 2005 -- Social aspects

K1 RETURN migration

K1 SOCIAL status

K1 HYPOTHESIS

K1 HOUSING

K1 DEMOGRAPHIC characteristics

K1 NEW Orleans (La.)

K1 LOUISIANA

K1 Environment

K1 Hurricane Katrina

K1 Migration

K1 Natural hazards

K1 New Orleans

K1 Race

K1 Socioeconomic status

AB Hurricane Katrina struck New Orleans on the 29th of August 2005 and displaced virtually the entire population of the city. Soon after, observers predicted the city would become whiter and wealthier as a result of selective return migration, although challenges related to sampling and data collection in a post-disaster environment have hampered evaluation of these hypotheses. In this article, we investigate return to the city by displaced residents over a period of approximately 14 months following the storm, describing overall return rates and examining differences in return rates by race and socioeconomic status. We use unique data from a representative sample of pre-Katrina New Orleans residents collected in the Displaced New Orleans Residents Pilot Survey. We find that black residents returned to the city at a much slower pace than white residents even after controlling for socioeconomic status and demographic characteristics. However, the racial disparity disappears after controlling for housing damage. We conclude that blacks tended to live in areas that experienced greater flooding and hence suffered more severe housing damage which, in turn, led to their delayed return to the city. The full-scale survey of displaced residents being fielded in 2009-2010 will show whether the repopulation of the city was selective over a longer period. ABSTRACT FROM AUTHOR]; Copyright of Population \& Environment is the property of Springer Science \& Business Media B.V. and its content may not be copied or emailed to multiple sites or posted to a listserv without the copyright holder's express written permission. However, users may print, download, or email articles for individual use. This abstract may be abridged. No warranty is given about the accuracy of the copy. Users should refer to the original published version of the material for the full abstract. (Copyright applies to all Abstracts.)

NO M3: Article

SN 01990039

AN 47968727

LK http://library.smu.ca:2048/login?http://search.ebscohost.com/login.aspx?

direct $=$ true $\& \mathrm{db}=8 \mathrm{gh} \& A \mathrm{~N}=47968727 \&$ site=ehost-live

DO 10.1007/s11111-009-0092-2

DS EBSCO

OL Unknown(0) 
RT Journal Article

SR Print(0)

ID 3151

A1 Gaillard,Jean-Christophe

T1 Alternative paradigms of volcanic risk perception: The case of Mt. Pinatubo in the Philippines

JF Journal of Volcanology and Geothermal Research

JO J.Volcanol.Geotherm.Res.

YR 2008

FD 5/20

VO 172

IS 3-4

SP 315

OP 328

$\mathrm{K} 1$ volcanic hazardrisk perception

K1 people's response

$\mathrm{K} 1$ access to resources

$\mathrm{K} 1$ cultural heritage

K1 Mt. Pinatubo

T2 Volcanic risk perception and beyond

SN 0377-0273

DO http://dx.doi.org/10.1016/j.jvolgeores.2007.12.036

DS ScienceDirect

UL http://www.sciencedirect.com/science/article/pii/S0377027307004234

OL Unknown(0)

RT Journal Article

SR Print(0)

ID 345

A1 Gaillard,Jean-Christophe

T1 Resilience of traditional societies in facing natural hazards

JF Disaster Prevention \& Management

YR 2007

FD 09/04

VO 16

IS 4

SP 522

OP 544

K1 HAZARD mitigation

K1 TRADITIONAL societies

K1 RESILIENCE (Personality trait)

K1 HAZARDS

$\mathrm{K} 1$ SOCIAL change

K1 SOCIAL systems

AB Purpose - This article sets out to address the response of traditional societies in facing natural hazards through the lens of the concept of resilience. Design/methodology/approach This paper considers that resilient societies are those able to overcome the damage caused by the occurrence of natural hazards, either through maintaining their pre-disaster social fabric, or through accepting marginal or larger change in order to survive. The discussion is based on a review of the corpus of case studies available in the literature. Findings - The present article suggests that the capacity of resilience of traditional societies and the concurrent degree of cultural change rely on four factors, namely: the nature of the hazard, the pre-disaster sociocultural context and capacity of resilience of the community, the geographical setting, and the 
rehabilitation policy set up by the authorities. These factors significantly vary in time and space, from one disaster to another. Practical implications - It is important to perceive local variations of the foregoing factors to better anticipate the capability of traditional societies to overcome the damage caused by the occurrence of natural hazards and therefore predict eventual cultural change. Originality/value - This article takes off from the previous vulnerability-driven literature by emphasizing the resilience of traditional societies. ABSTRACT FROM AUTHOR]; Copyright of Disaster Prevention \& Management is the property of Emerald Group Publishing Limited and its content may not be copied or emailed to multiple sites or posted to a listserv without the copyright holder's express written permission. However, users may print, download, or email articles for individual use. This abstract may be abridged. No warranty is given about the accuracy of the copy. Users should refer to the original published version of the material for the full abstract. (Copyright applies to all Abstracts.)

NO M3: Article

SN 09653562

AN 26647365

LK file:///C:/Users/s9130263/Documents/Cases/Gaillard_2007.pdf

DS EBSCO

OL Unknown(0)

RT Journal Article

SR Print(0)

ID 1727

A1 Gallard,Jean-Christophe

A1 Le Masson,Virginie

T1 Traditional societies' response to volcanic hazards in the Philippines; implications for community-based disaster recovery

JF Mountain Research and Development

YR 2007

FD November 2007

VO 27

IS 4

SP 313

OP 317

K1 Luzon

K1 Far East

$\mathrm{K} 1$ geologic hazards

$\mathrm{K} 1$ effects

K1 human ecology

$\mathrm{K} 1$ adaptation

$\mathrm{K} 1$ volcanic risk

K1 Mount Pinatubo

K1 Philippine Islands

$\mathrm{K} 1$ eruptions

$\mathrm{K} 1$ natural hazards

K1 Asia

K1 catastrophes

K1 22:Environmental geology

NO Source type: scholarlyjournals; Object type: Article; Copyright: GeoRef, Copyright 2013, American Geosciences Institute.; CSAUnique: 2013-019058; AccNum: 2013-019058; DOI:

10.1659/mrd.0949; ISSN: 0276-4741; Peer Reviewed: true

PB International Mountain Society, Boulder, CO

PP Boulder, CO, United States (USA)

SN 0276-4741, 0276-4741

AN 1287375164; 2013-019058 
LA English

LK file://C:/Users/s9130263/Documents/Cases/Gaillard_\&_LeMasson_2007.pdf

DO http://dx.doi.org/10.1659/mrd.0949

DB GeoRef

DS ProQuest

UL http://QN8PM6GK2Q.search.serialssolutions.com/directLink?

\&atitle=Traditional+societies \%2527+response+to+volcanic+hazards+in+the+Philippines\%253

B+implications+for+community-based+disaster+recovery\&author=Gallard\%252C+Jean-

Christophe\%253BLe+Masson\%252C+Virginie\&issn=02764741\&title=Mountain+Research+and +Development\&volume=27\&issue =4\&date=2007-11-01\&spage=313\&id=doi:

10.1659\%252Fmrd.0949\&sid=ProQ_ss\&genre=article; http://www.mrd-journal.org/; http://

dx.doi.org/10.1659/mrd.0949; http://www.mrd-journal.org/

OL Unknown(0)

RT Journal Article

SR Print(0)

ID 1333

A1 Gawith,Elizabeth (Libby)

T1 The on-going psychological toll from the Canterbury earthquakesStories from one community

JF Disaster Prevention \& Management

YR 2013

FD 12

VO 22

IS 5

SP 395

OP 404

K1 EARTHQUAKES

K1 SEISMIC waves

K1 FAMILIES

K1 STUDENTS

$\mathrm{K} 1$ TEACHERS

K1 NEW Zealand

K1 Community recovery

K1 Disasters

K1 Phases of recovery

K1 Psychological recovery

AB Purpose - The purpose of this paper is to capture the stories of earthquake experiences from one community and relate this material to some of the psychological phases of recovery from a disaster. Design/methodology/approach - The approach taken was qualitative, explorative and participatory. The researchers were partners in the school project, as the school determined its own methodology, participation and end result. The audio or video interviews were open-ended and explored broad themes, in groups and individuals.

Participants included multiple members of the same families. The stories of the participants were used to illustrate the psychological phases of recovery. Findings - The experiences of the research participants were reviewed through the psychological phases of recovery highlighted in the literature (e.g. Myers and Zunin, 2000). The phases identified in the stories indicate that the Christchurch situation is consistent with international experience. Additional psychological responses such as community bonding and resilience, as well as living with secondary stressors, were also identified. Research limitations/implications - There are some commonalities apparent for this group of interviewees, for example, many were together at the school, at the time of the 22 February 2011 earthquake. However, there are also many differences and unique experiences and as such, only tentative generalisations can be made from these interviews. Originality/value - The paper contributes to the wider collection of 
research on and about the Canterbury earthquakes by discussing elements of psychological recovery through the experiences of one community of parents, teachers and primary school children. ABSTRACT FROM AUTHOR]; Copyright of Disaster Prevention \& Management is the property of Emerald Group Publishing Limited and its content may not be copied or emailed to multiple sites or posted to a listserv without the copyright holder's express written permission. However, users may print, download, or email articles for individual use. This abstract may be abridged. No warranty is given about the accuracy of the copy. Users should refer to the original published version of the material for the full abstract. (Copyright applies to all

Abstracts.)

NO M3: Article

SN 09653562

AN 93511592

LK http://library.smu.ca:2048/login?http://search.ebscohost.com/login.aspx?

direct $=$ true $\& d b=a p h \& A N=93511592 \&$ site $=$ ehost-live

DO 10.1108/DPM-10-2013-0180

DS EBSCO

OL Unknown(0)

RT Journal Article

SR Print(0)

ID 1463

A1 Gentle,Popular

A1 Maraseni,Tek Narayan

T1 Climate change, poverty and livelihoods: adaptation practices by rural mountain communities in Nepal

JF Environmental Science \& Policy

JO Environ.Sci.\& Policy

YR 2012

FD 08

VO 21

SP 24

OP 34

K1 CLIMATIC changes

K1 POVERTY

K1 EQUALITY

K1 SOCIAL problems

K1 WEALTH

K1 NEPAL

AB Abstract: Effects of climate change tend to be more severe where people rely on weather dependent rain-fed agriculture for their livelihoods. In rural mountain communities with limited livelihood options, adaptive capacity is low due to limited information, poor access to services, and inequitable access to productive assets. Few studies have reported on the current status of rural and remote mountain areas in Nepal with little known about adaptation strategies in use. This article is based on a study in the remote mountainous Jumla District of Nepal to explore how climate change is affecting the livelihood of local communities and how different wellbeing groups are differentially impacted. Looking from a wellbeing lens, adaptation practices by households as well as local support mechanisms were explored to predict the severity of effects now and into the future. Using a climate vulnerability and capacity analysis (CVCA) process, major climate hazards and their effects on livelihood resources were analyzed. In addition, participatory social research methods were used to analyze the coping strategies of different wellbeing groups. Results show that changing weather patterns have significantly challenged the livelihoods of a community, experiencing resource degradation, food scarcity, lack of basic services, and increasing social inequalities. The changing climate is an additional burden to the poor people in the mountains who are already living in poverty, are vulnerable 
and excluded with predictions of additional risks to livelihoods and further inequity in the future. Copyright \&y\& Elsevier]; Copyright of Environmental Science \& Policy is the property of Elsevier Science Publishing Company, Inc. and its content may not be copied or emailed to multiple sites or posted to a listserv without the copyright holder's express written permission. However, users may print, download, or email articles for individual use. This abstract may be abridged. No warranty is given about the accuracy of the copy. Users should refer to the original published version of the material for the full abstract. (Copyright applies to all

Abstracts.)

NO M3: Article

SN 14629011

AN 77461796

LK http://library.smu.ca:2048/login?http://search.ebscohost.com/login.aspx?

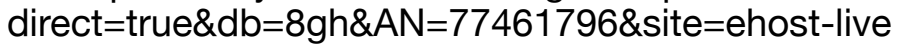

DO 10.1016/j.envsci.2012.03.007

DS EBSCO

OL Unknown(0)

RT Journal Article

SR Print(0)

ID 527

A1 Gismondi,M.

T1 Investigating community behaviour after the 2004 Chuetsu earthquake: A case study of Kawaguchi, Japan

JF Social Geography

YR 2012

VO 7

IS 1

SP 1

$\mathrm{K} 1$ community organization

$\mathrm{K} 1$ earthquake damage

$\mathrm{K} 1$ earthquake engineering

$\mathrm{K} 1$ earthquake event

$\mathrm{K} 1$ educational development

K1 human behavior

$\mathrm{K} 1$ policy approach

$\mathrm{K} 1$ questionnaire survey

$\mathrm{K} 1$ rural area

$\mathrm{K} 1$ safety

$\mathrm{K} 1$ socioeconomic impact

$\mathrm{K} 1$ theoretical study

$A B$ Every year, earthquakes cause economic and human losses around the globe. In Japan, a great deal of attention has focused on improving the safety of structures and individuals in the last decade. The introduction here of several new related policies, together with continuous discussion of such policies, has raised the level of environmental security nationwide. Despite this significant effort, individual preparedness and awareness are still lacking, especially in rural areas, where technological advancements and policy applications often arrive late. In this paper, Kawaguchi in Niigata Prefecture, Japan was chosen as study area because of both the major damage experienced during the 2004 Chuetsu earthquake and the particularly dynamic socio-cultural activities of the community. Using interviews and questionnaires to collect information, this study aims to investigate the causes of local variations in community behaviour after the earthquake. Geographic location as well as everyday social relationships, social interactions and organization are considered the main causes of the differences in community organisation during the recovery process. This study highlights the necessity for 
more localised emergency education in order to promote longer-lasting awareness and preparation in rural areas. \&copy; Author(s) 2012.

PP Bahnhofsallee 1e, Goettingen, 37081, Germany

SN 17294274

LA English

LK http://dx.doi.org/10.5194/sg-7-1-2012

DB Compilation and indexing terms, Copyright 2013 Elsevier Inc.; GEOBASE

OL Unknown(0)

RT Journal Article

SR Print(0)

ID 603

A1 Goemans, Magdalene

A1 Ballamingie,Patricia

T1 Forest as hazard, forest as victim: Community perspectives and disaster mitigation in The aftermath of Kelowna's 2003 wildfires

JF Canadian Geographer

YR 2013

VO 57

IS 1

SP 56

K1 disaster management

K1 forest fire

K1 forest management

$\mathrm{K} 1$ hazard assessment

$\mathrm{K} 1$ risk assessment

$\mathrm{K} 1$ sense of place

$\mathrm{K} 1$ sustainable forestry

K1 urban forestry

K1 vulnerability

K1 wildfire

AB Situated within The political ecology of hazard, This article is an extended case study of

The devastating 2003 wildfires in and around Kelowna, British Columbia (also known as The

Okanagan Mountain Park Fire). This article reveals how compliance (or lack Thereof) with fire

mitigation strategies recommended by provincial, regional, and municipal agencies is

complicated by differing social constructions of what constitutes ecologically sustainable forest management and community safety. Three perspectives emerge regarding The urban forests:

"nature as hazard" - a volatile force To be controlled; "nature as instrumentally valuable" - a contribution To The character of one's surroundings and subsequent sense of place; and "nature as intrinsically valuable" - a distinct entity To be preserved and protected for its own sake. The article also examines how experiences of disaster influence community perceptions and result in a greater willingness To engage in fire mitigation strategies due To perceptions of heightened vulnerability. Forestry and fire mitigation agencies need To determine multiple courses of action among The varied and valid range of residents' nature perspectives. The role of human agency in disaster mitigation must be examined, particularly as The risk of fire at The wildland-urban interface continues To be exacerbated by encroaching human settlements and climate change. \&copy; Canadian Association of Geographers / L'Association canadienne des g'e\&acute;ographes.

PP 350 Main Street, Malden, MA 02148, United States

SN 00083658

LA English

LK http://dx.doi.org/10.1111/j.1541-0064.2012.00447.x

DB Compilation and indexing terms, Copyright 2013 Elsevier Inc.; GEOBASE

OL Unknown(0) 
RT Journal Article

SR Print(0)

ID 1454

A1 Gómez-Baggethun,Erik

A1 Reyes-García,Victoria

A1 Olsson,Per

A1 Montes, Carlos

T1 Traditional ecological knowledge and community resilience to environmental extremes: A case study in Doñana, SW Spain

JF Global Environmental Change Part A: Human \& Policy Dimensions

YR 2012

FD 08

VO 22

IS 3

SP 640

OP 650

K1 TRADITIONAL ecological knowledge

K1 GLOBAL environmental change

K1 CASE studies

K1 ACQUISITION of data

K1 FINANCIAL crises

K1 ECOSYSTEM services

K1 ECOLOGICAL economics

K1 SPAIN

K1 Doñana

AB Abstract: Research in the last decade has emphasised the potential contribution of traditional ecological knowledge to cope with challenges from global environmental change. This research examines the role of traditional ecological knowledge and shared systems of beliefs in building long-term social-ecological resilience to environmental extremes. Data were collected from 13 villages of the Doñana region, southwestern Spain, through interviews, focus groups, and systematic reviews of historical archives. First, we assess adaptive practices to cope with environmental change. Then, we use historical records of religious ceremonies (1577-1956) to reconstruct collective responses to environmental extremes. Our results (1) show how environmental extremes could induce social and economic crises through declines in ecosystem services and (2) identify practices to cope with recurrent disturbance and institutional devices developed in response to environmental extremes. We conclude that traditional ecological knowledge and shared systems of beliefs can facilitate collective responses to crises and contribute to the maintenance of long-term resilience of socialecological systems. Copyright \&y\& Elsevier]; Copyright of Global Environmental Change Part A: Human \& Policy Dimensions is the property of Pergamon Press - An Imprint of Elsevier Science and its content may not be copied or emailed to multiple sites or posted to a listserv without the copyright holder's express written permission. However, users may print, download, or email articles for individual use. This abstract may be abridged. No warranty is given about the accuracy of the copy. Users should refer to the original published version of the material for the full abstract. (Copyright applies to all Abstracts.)

NO M3: Article

SN 09593780

AN 79560517

LK http://library.smu.ca:2048/login?http://search.ebscohost.com/login.aspx?

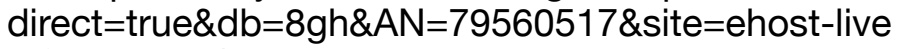

DO 10.1016/j.gloenvcha.2012.02.005

DS EBSCO

OL Unknown(0) 
RT Journal Article

SR Print(0)

ID 557

A1 Gupta,Kapil

T1 Urban flood resilience planning and management and lessons for the future: A case study of Mumbai, India

JF Urban Water Journal

YR 2007

VO 4

IS 3

SP 183

K1 flash flood

K1 flood control

K1 landslide

K1 rainfall

K1 urban drainage

AB Mumbai city, having an area of $437 \mathrm{~km} 2$ with a population of 12 million, came to a complete halt owing to the unprecedented rainfall of $994 \mathrm{~mm}$ during the 24 hours starting 08:30 on 26

July 2005. At least 419 people (and 16000 cattle) were killed as a result of the ensuing flash floods and landslides in Mumbai municipal area, and another 216 as a result of flood-related illnesses. Over 100000 residential and commercial establishments and 30000 vehicles were damaged. The current paper describes Mumbai's drainage system, the details of the flooding and the measures being taken by the city to mitigate such floods in the future. The Mumbai experience would be helpful for planning response strategies for other large cities to cope with similar events in the future.

NO Bos;

SN 1573062X

LA English

LK http://dx.doi.org/10.1080/15730620701464141

DB Compilation and indexing terms, Copyright 2013 Elsevier Inc.; GEOBASE

OL Unknown(0)

RT Journal Article

SR Print(0)

ID 543

A1 Harte,E. Wendy

A1 Childs, Iraphne R. W.

A1 Hastings, Peter A.

T1 Imizamo Yethu: A case study of community resilience to fire hazard in an informal settlement Cape Town, South Africa

JF Geographical Research

YR 2009

VO 47

IS 2

SP 142154

K1 community response

$\mathrm{K} 1$ damage

$\mathrm{K} 1$ environmental hazard

$\mathrm{K} 1$ environmental impact

$\mathrm{K} 1$ fire

$\mathrm{K} 1$ hazard management

$\mathrm{K} 1$ informal settlement

$\mathrm{K} 1$ local participation 
K1 social network

K1 urban area

K1 vulnerability

AB Imizamo Yethu, in Cape Town, is one of the many informal settlements in South Africa's post-Apartheid urban landscape. Residents live in abject poverty and are potentially vulnerable to a range of environmental hazards, of which fire hazard is one of the most common. A major fire, on the 8 February 2004, caused significant damage to housing and infrastructure, resulting in widespread homelessness and loss of personal possessions. Despite this, there was minimal loss of life and few major injuries. The community re-grouped after the fire and Imizamo Yethu has remained viable as a community to the present day. Contemporary geographical research on hazards emphasises aspects of community vulnerability and resilience. The present paper identifies and examines factors that enhance community resilience in the informal settlement of Imizamo Yethu, particularly in response and recovery to fire events. A survey completed in the aftermath of the 2004 fire found that social networks, some formal community institutions that foster community participation and the resourcefulness of individuals were the most important factors underpinning resilience. \&copy; 2009 Institute of Australian Geographers.

SN 17455863

LA English

LK file://C:/Users/s9130263/Documents/Cases/Harte_etal_2008.pdf;

DB Compilation and indexing terms, Copyright 2013 Elsevier Inc.; GEOBASE

OL Unknown(0)

RT Journal Article

SR Print(0)

ID 317

A1 He,Lili

A1 Xu,Jiuping

A1 Wu,Zhibin

T1 Coping Strategies as a Mediator of Posttraumatic Growth among Adult Survivors of the Wenchuan Earthquake

JF PLOS ONE

YR 2013

FD 12

VO 8

IS 12

SP 1

OP 7

K1 WENCHUAN Earthquake, China, 2008

K1 SOCIAL support

K1 PSYCHOLOGY

K1 MEDIATION (Statistics)

K1 MENTAL health

K1 CORRELATION (Statistics)

K1 Adjustment (psychology)

K1 Behavior

K1 Medicine

K1 Psychological stress

K1 Research Article

K1 Social psychology

$\mathrm{AB}$ Objective: By testing the mediating effect of coping strategies on the relationship between social support (SS) and posttraumatic growth (PTG), the aim of this research was to develop a new approach for the study of post-disaster psychological intervention. Methods: A mediating effect model analysis was conducted on 2080 adult survivors selected from 19 of the counties hardest-hit by the 2008 Wenchuan earthquake. The Social Support Rating Scale and the 
Coping Scale were used to predict the PTG. Results: A bivariate correlation analysis showed that there was a correlation between posttraumatic growth, social support and coping strategies. The mediation analysis revealed that coping strategies played a mediating role between social support and posttraumatic growth in survivors after the earthquake.

Conclusion: The results demonstrated that mental health programs for survivors need to focus on the establishment of a good social support network, which was found to be conductive to maintaining and increasing mental health levels. At the same time, adequate social support is able to assist survivors in adopting mature coping strategies, such as problem solving and asking for help. Hence, social support was found to play a vital role in balancing and protecting mental health. ABSTRACT FROM AUTHOR]; Copyright of PLoS ONE is the property of Public Library of Science and its content may not be copied or emailed to multiple sites or posted to a listserv without the copyright holder's express written permission. However, users may print, download, or email articles for individual use. This abstract may be abridged. No warranty is given about the accuracy of the copy. Users should refer to the original published version of the material for the full abstract. (Copyright applies to all Abstracts.)

NO M3: Article

PB Public Library of Science

SN 19326203

AN 93397928

LK C:\Users\s9130263\Documents\Cases\He_etal_2013.pdf

DO 10.1371/journal.pone.0084164

DS EBSCO

OL Unknown(0)

RT Journal Article

SR Print(0)

ID 1029

A1 Hernández-Guerrero,Juan

A1 Vieyra-Medrano,Antonio

A1 Mendoza,M. E.

T1 Adaptation strategies in communities under precarious housing: Flooding risks in the periurban sector of the city of Morelia, Michoacán, México

JF Applied Geography

JO Appl.Geogr.

YR 2012

FD 05

VO 34

SP 669

OP 679

K1 FLOODS -- Risk assessment

$\mathrm{K} 1 \mathrm{CITIES} \&$ towns

K1 STRATEGIC planning

K1 HOUSING

K1 MATHEMATICAL models

K1 BIODIVERSITY

K1 MORELIA (Michoacan de Ocampo, Mexico)

K1 MEXICO

AB Abstract: Current literature on peri-urban spaces emphasizes that these areas are characterized by their dynamism, heterogeneity, soil-use diversity, susceptibility to change and occupancy by poor and vulnerable people in risk-prone areas. This paper analyzes the adjustment strategies implemented by people living under precarious housing conditions in two flood-prone communities located in the periphery of the city of Morelia. Additionally, it discusses how these strategies affect the adaptive capacity of each community for future flooding events. The study is based on methodologies that integrate a flooding model and a 
precarious-housing model. We correlated these models to define zones where the adaptive capacities of the affected population are compared by applying surveys and semi-structured interviews. Results from the study show that poverty and housing precariousness have prompted the establishment of new settlements in areas that are not adequate for urban development due to flood conditions. These flood conditions have been further enhanced by poor planning strategies and rudimentary housing improvements implemented by the people. The latter has been an adaptive process by which populations adjust to risk after each flooding event. This study makes a methodological contribution and the precariousness model we developed can be applied to other scenarios under similar conditions. Copyright \&y\& Elsevier]; Copyright of Applied Geography is the property of Pergamon Press - An Imprint of Elsevier Science and its content may not be copied or emailed to multiple sites or posted to a listserv without the copyright holder's express written permission. However, users may print, download, or email articles for individual use. This abstract may be abridged. No warranty is given about the accuracy of the copy. Users should refer to the original published version of the material for the full abstract. (Copyright applies to all Abstracts.)

NO M3: Article

SN 01436228

AN 76494371

LK http://library.smu.ca:2048/login?http://search.ebscohost.com/login.aspx?

direct=true\&db=aph\&AN=76494371\&site=ehost-live

DO 10.1016/j.apgeog.2012.04.010

DS EBSCO

OL Unknown(0)

RT Book, Section

SR Print(0)

ID 1623

A1 Hobson,Alexis

T1 Chapter 8: The Responses of Residents of Nevis to Hurricane Threat: The Case of Hurricane Hugo

JF Resources, Planning \& Environmental Management in a Changing Caribbean

YR 2003

FD 01

SP 153

OP 172

K1 HURRICANES

K1 HURRICANE protection

K1 HURRICANE Hugo, 1989

K1 NATURAL disaster warning systems

K1 NEVIS

AB Chapter 8 of the book "Resources, Planning \& Environmental Management in a Changing Caribbean" is presented. It discusses that factors that affect human response to hurricane hazard as demonstrated by the people of Nevis during and after the onslaught of Hurricane Hugo in 1989. Two hypotheses that explain the response to Hurricane Hugo are analyzed.

NO M3: Book Chapter

SN 9789766401344

AN 31590111

LK http://library.smu.ca:2048/login?http://search.ebscohost.com/login.aspx?

direct=true\&db=8gh\&AN=31590111\&site=ehost-live

DS EBSCO

OL Unknown(0)

RT Journal Article

SR Print(0) 
ID 565

A1 Hughey,Erin P.

A1 Tobin,Graham A.

T1 Hazard response capabilities of a small community: A case study of Falmouth, Kentucky and the 1997 flood

JF Southeastern Geographer

YR 2006

VO 46

IS 1

SP 66

$\mathrm{K} 1$ community response

$\mathrm{K} 1$ disaster management

$\mathrm{K} 1$ disaster relief

K1 flood

AB In the early 1990s there were approximately 22,000 communities in the United States located in whole or in part of the $5 \%$ of U.S. land area comprised of floodplains (Kusler and Larson 1993). Significant flood losses occur in the U.S. every year, making flooding the leading natural hazard. Disparities exist in the hazards literature with regards to the response capabilities of small communities to disasters. The primary intent of this research is to examine the capacity of small communities to respond to disasters by analyzing official and unofficial records of hazard mitigation and response activities within Falmouth, Kentucky before and after a 1997 flood event. Qualitative and quantitative methods were utilized to establish the community's ability to respond to the flood which impacted over $80 \%$ of the community. Wellestablished community relationships were identified as the elements intrinsic to small community hazard response.

SN 0038366X

LA English

DB Compilation and indexing terms, Copyright 2013 Elsevier Inc.; GEOBASE

OL Unknown(0)

RT Journal Article

SR Print(0)

ID 1382

A1 Hur,Joon-Young

T1 Disaster management from the perspective of governance: case study of the Hebei Spirit oil spill

JF Disaster Prevention \& Management

YR 2012

FD 08

VO 21

IS 3

SP 288

OP 298

K1 EMERGENCY management

K1 OIL spills

K1 CASE studies

K1 KOREA (South)

K1 HEBEI Sheng (China)

K1 CHINA

K1 Disaster management

K1 Governance

K1 Oil pollution

K1 Oil spill

K1 Oil tankers 
K1 Private sector

K1 Public sector

K1 South Korea

K1 Trust

AB Purpose |!|\#8211; The purpose of this paper is to attempt, from the perspective of governance, to approach and analyze the cooperation mechanisms as were shown in the case of the Hebei Spirit oil spill disaster management. Design/methodology/approach |!|\#8211; The paper described the structure of that governance and examines the relations between actors. On the basis of this information the inner dynamics within their interactions were investigated and key factors for and hindrances to the success were identified. Findings |!|\#8211; Solidarity culture, personal communication media and a wide participation of private actors turned out to be helpful to cooperative mechanisms, whereas the lack of responsiveness of government and the unclear boundary of responsibilities between public organizations stood in the way of harmonious and effective governance. Practical implications |!|\#8211; The paper shows that it is a requisite to have a comprehensive approach and pragmatic policies as well as their implementation mechanisms. There is also a requirement for effective consultation, collaboration and coordination, progress monitoring and above all, the will. Originality/value |!| \#8211; The research leads to the conclusion that the cooperation between public and private sectors in the case of that oil spill disaster shows a possibility of a new paradigm of interactive dialog within the society and thus can be interpreted as governance. ABSTRACT FROM

AUTHOR]; Copyright of Disaster Prevention \& Management is the property of Emerald Group Publishing Limited and its content may not be copied or emailed to multiple sites or posted to a listserv without the copyright holder's express written permission. However, users may print, download, or email articles for individual use. This abstract may be abridged. No warranty is given about the accuracy of the copy. Users should refer to the original published version of the material for the full abstract. (Copyright applies to all Abstracts.)

NO M3: Article

SN 09653562

AN 79916291

LK file:///C:/Users/s9130263/Documents/Cases/Hur_2012.pdf

DO 10.1108/09653561211234471

DS EBSCO

OL Unknown(0)

RT Journal Article

SR Print(0)

ID 43

A1 Hutter,Gerard

A1 Kuhlicke,Christian

T1 Resilience, Talk and Action: Exploring the Meanings of Resilience in the Context of Planning and Institutions

JF Planning Practice and Research

YR 2013

VO 28

IS 3

SP 294

K1 crisis management

K1 flood control

K1 flooding

$\mathrm{K} 1$ planning system

$A B$ The meaning of the word resilience varies according to the social context. To enhance a dynamic understanding of resilience, the paper analyses its elusive character from a sensemaking perspective. Resilience is understood as a content of sensemaking processes in the context of a crisis. Four processes are explored in some detail using findings from a case 
study about dealing with an extreme flood event in a small town in Germany. These four processes are commitment to resilience, expecting resilience, arguing about resilience and resilience and manipulation. Implications for planning research and practice are thereby revealed. \&copy; 2013 Copyright Taylor and Francis Group, LLC.

PP 4 Park Square, Milton Park, Abingdon, Oxfordshire, OX14 4RN, United Kingdom SN 02697459

LA English

LK http://dx.doi.org/10.1080/02697459.2013.787706

DB Compilation and indexing terms, Copyright 2013 Elsevier Inc.; GEOBASE

OL Unknown(0)

RT Journal Article

SR Print(0)

ID 2667

A1 Irish,Jennifer L.

A1 Lynett,Patrick J.

A1 Weiss, Robert

A1 Smallegan,Stephanie M.

A1 Cheng,Wei

T1 Buried relic seawall mitigates Hurricane Sandy's impacts

JF Coastal Engineering

JO Coast.Eng.

YR 2013

FD 10

VO 80

IS 0

SP 79

OP 82

K1 Hurricanes

K1 Storm surge

K1 Waves

K1 Storm damage

K1 Seawalls

SN 0378-3839

DO http://dx.doi.org/10.1016/j.coastaleng.2013.06.001

DS ScienceDirect

UL http://www.sciencedirect.com/science/article/pii/S0378383913001099

OL Unknown(0)

RT Journal Article

SR Print(0)

ID 2003

A1 Jacob,Binu

A1 Mawson,Anthony R.

A1 Payton, Marinelle

A1 Guignard,John C.

T1 Disaster Mythology and Fact: Hurricane Katrina and Social Attachment

JF Public Health Reports (1974-)

YR 2008

FD SEPTEMBER/OCTOBER

VO 123

IS 5

SP 555

OP 566 
AB Misconceptions about disasters and their social and health consequences remain prevalent despite considerable research evidence to the contrary. Eight such myths and their factual counterparts were reviewed in a classic report on the public health impact of disasters by Claude de Ville de Goyet entitled, The Role of WHO in Disaster Management: Relief, Rehabilitation, and Reconstruction (Geneva, World Health Organization, 1991), and two additional myths and facts were added by Pan American Health Organization. In this article, we reconsider these myths and facts in relation to Hurricane Katrina, with particular emphasis on psychosocial needs and behaviors, based on data gleaned from scientific sources as well as printed and electronic media reports. The review suggests that preparedness plans for disasters involving forced mass evacuation and resettlement should place a high priority on keeping families together - and even entire neighborhoods, where possible-so as to preserve the familiar and thereby minimize the adverse effects of separation and major dislocation on mental and physical health.

PB Association of Schools of Public Health

SN 00333549

LA English

SF research-article; Copyright (C) 2008 Association of Schools of Public Health

LK http://www.jstor.org/stable/25682097

DS JSTOR

OL Unknown(0)

RT Journal Article

SR Print(0)

ID 1933

A1 Jason Corburn

T1 Combining Community-Based Research and Local Knowledge to Confront Asthma and

Subsistence-Fishing Hazards in Greenpoint/Williamsburg, Brooklyn, New York

JF Environmental health perspectives

JO Environ. Health Perspect.

YR 2002

FD Apr.

VO 110

IS , Supplement 2: Community, Research, and Environmental Justice

SP 241

OP 248

AB Activists in the environmental justice movement are challenging expert-driven scientific research by taking the research process into their own hands and speaking for themselves by defining, analyzing, and prescribing solutions for the environmental health hazards confronting communities of the poor and people of color. I highlight the work of El Puente and The Watchperson Project-two community-based organizations in the Greenpoint/Williamsburg neighborhood in Brooklyn, New York, that have engaged in community-based participatory research (CBPR) to address asthma and risks from subsistence-fish diets. The CBPR process aims to engage community members as equal partners alongside scientists in problem definition, information collection, and data analysis-all geared toward locally relevant action for social change. In the first case I highlight how El Puente has organized residents to conduct a series of asthma health surveys and tapped into local knowledge of the Latino population to understand potential asthma triggers and to devise culturally relevant health interventions. In a second case I follow The Watchperson Project and their work surveying subsistence anglers and note how the community-gathered information contributed key data inputs for the U.S. Environmental Protection Agency Cumulative Exposure Project in the neighborhood. In each case I review the processes each organization used to conduct CBPR, some of their findings, and the local knowledge they gathered, all of which were crucial for understanding and addressing local environmental health issues. I conclude with some observations about the 
benefits and limits of CBPR for helping scientists and communities pursue environmental justice.

PB Brogan \& Partners

SN 00916765

LA English

SF research-article; Copyright (C) 2002 The National Institute of Environmental Health Sciences (NIEHS)

LK http://www.jstor.org/stable/3455059

DS JSTOR

OL Unknown(0)

RT Journal Article

SR Print(0)

ID 495

A1 Jeffery,S. E.

T1 The creation of vulnerability to natural disaster: case studies from the Dominican Republic.

JF Disasters

JO Disasters

YR 1982

VO 6

IS 1

SP 38

K1 commercialized agricultural production

$\mathrm{K} 1$ economic change

$\mathrm{K} 1$ hazards

K1 natural disasters

K1 vulnerability

$A B$ Argues that natural disasters are not a category of events which can be separated from the broader issues of development, since economic change can create vulnerability to natural disaster. The analysis of case studies from the Dominican Republic shows how the development of large scale commercialized agricultural production has created such vulnerability by reducing or restricting the resource base of certain sectors of the population. It is suggested that the vulnerable state of a population should be considered as much a cause of natural disaster as the extreme physical phenomena involved. Therefore, there is a need both for a broader framework for analysis of disasters and for strategies to reduce such vulnerability to be an integral part of long term development planning.-Author SN 03613666

LA English

DB Compilation and indexing terms, Copyright 2013 Elsevier Inc.; GEOBASE OL Unknown(0)

RT Journal Article

SR Print(0)

ID 606

A1 Jenkins,David Harrison

A1 Harris,Anthony

A1 Tair,Abdul Abu

A1 Thomas, Hilary

A1 Okotel,Richard

A1 Kinuthia,John

A1 Mofor,Linus

A1 Quince,Marga

T1 Community-based resilience building: Normative meets narrative in Mbale, 2010/2011 JF Environmental Hazards 
YR 2013

VO 12

IS 1

SP 47

$\mathrm{K} 1$ disaster relief

K1 human settlement

$\mathrm{K} 1$ landslide

$\mathrm{K} 1$ numerical model

K1 poverty

$\mathrm{K} 1$ resilience

$\mathrm{K} 1$ risk assessment

$\mathrm{AB}$ This article provides a comparative analysis of normative and community-to-communitybased approaches to resilience building. A narrative rendering of events in Bududa in 2010 is provided through the lens of a community-to-community partnership. The comparison is then achieved through a picture of a normative model for low-impact (cyclical), highfrequency disasters drawn from documentary resources. The narrative element is provided through a case study of the landslides in Bududa, in the Mbale region of Uganda in spring 2010. This event killed over 300 people and led to the temporary displacement of as many as 8000 and the permanent displacement of an undisclosed number. A preliminary evaluation of the Mbale experience is offered, showing the limitations of normative models, describing current resilience-building activities and opening the current discussion within the Mbale Coalition against Poverty to public scrutiny. \&copy; 2013 Taylor \& Francis.

PP 4 Park Square, Milton Park, Abingdon, Oxfordshire, OX14 4RN, United Kingdom

SN 17477891

LA English

LK http://dx.doi.org/10.1080/17477891.2012.738641

DB Compilation and indexing terms, Copyright 2013 Elsevier Inc.; GEOBASE

OL Unknown(0)

RT Journal Article

SR Print(0)

ID 2287

A1 Jenkins,Pam

A1 Phillips,Brenda

T1 Battered Women, Catastrophe, and the Context of Safety after Hurricane Katrina

JF NWSA Journal

YR 2008

FD Fall

VO 20

IS 3, New Orleans: A Special Issue on Gender, the Meaning of Place, and the Politics of Displacement

SP 49

OP 68

AB Feminist practice, activism, and scholarship have played critical roles in bringing the problems of domestic violence to light, shaping legislation to empower victims and championing improvement in advocacy and outreach. Yet many women and children not only continue to suffer from this form of personal violence, but suffer doubly when large-scale catastrophes strike--even as large numbers of volunteers turn out to respond, donors overwhelm local communities, and people open their hearts to those in need. This paper examines domestic violence and disaster in post-Hurricane Katrina New Orleans while concomitantly contributing to the literature that demonstrates ways in which feminist orientations can make vital differences in disaster contexts. We show that by listening to the voices of victims in postdisaster contexts, new insights can be gleaned as to how to make all women safer during disasters. Domesticviolence survivors often experienced heightened levels 
of violence during the hurricane and its aftermath; however, even in that difficult context, some women made the choice to leave abusive situations and advocates responded in new ways to help these women meet their unique needs.

PB The Johns Hopkins University Press

SN 10400656

LA English

SF research-article; Copyright (C) 2008 The Johns Hopkins University Press

LK http://www.jstor.org/stable/40071296

DS JSTOR

OL Unknown(0)

RT Journal Article

SR Print(0)

ID 180

A1 Julich,Sebastian

T1 Drought Triggered Temporary Migration in an East Indian Village

JF International Migration

JO Int.Migr.

YR 2011

VO 49

IS SUPPL.1

SP e189

K1 coping strategy

K1 drought

K1 forced migration

K1 labor migration

K1 migration determinant

$\mathrm{K} 1$ natural disaster

$\mathrm{K} 1$ population migration

$\mathrm{K} 1$ rural population

$A B$ This case study in the village of Khaliakani examines the impact of drought disasters on the rural population in the Indian state Orissa and analyses the importance of temporary migration as a coping and adaptation strategy. Social, economic, and spatial patterns of the forced migration caused by the last drought disaster in 2003 are being investigated at the household level in order to explore the links between vulnerability and temporary migration for labour. The drivers leading to environmental forced migration, the requirements necessary to migrate, and the resulting outcomes for the migrants are explored and comprised in a conceptual model of environmental forced migration for labour. \&copy; 2011 The Author. International Migration \&copy; 2011 IOM.

PP 9600 Garsington Road, Oxford, OX4 2XG, United Kingdom

SN 00207985

LA English

LK http://dx.doi.org/10.1111/j.1468-2435.2010.00655.x

DB Compilation and indexing terms, Copyright 2013 Elsevier Inc.; GEOBASE

OL Unknown(0)

RT Journal Article

SR Print(0)

ID 2334

A1 Kale-Lostuvli,Elif

T1 Negotiating State Provision: State-Citizen Encounters in the Aftermath of the Izmit Earthquake

JF The Sociological Quarterly

YR 2007 
FD Fall

VO 48

IS 4

SP 745

OP 767

AB The Izmit Earthquake ( August 17, 1999) was the most destructive disaster in the history of the Turkish Republic and a major trial for the Turkish state. This article draws on the sociological literature on social citizenship and welfare states to examine the state provision process that followed the disaster. On the basis of ethnographic data collected in the aftermath of the earthquake, I describe how state provision was shaped by the everyday encounters between state agents and survivors, and uncover the cultural repertoire employed in these encounters. I argue that state provision in Turkey is governed by the paternalistic state discourse. I then discuss the historical roots and implications of this finding.

PB Wiley on behalf of the Midwest Sociological Society

SN 00380253

LA English

SF research-article; Copyright (C) 2007 Midwest Sociological Society

LK http://www.jstor.org/stable/40220050

DS JSTOR

OL Unknown(0)

RT Journal Article

SR Print(0)

ID 331

A1 Kartiki,Katha

T1 Climate change and migration: a case study from rural Bangladesh

JF Gender \& Development

YR 2011

FD 03

VO 19

IS 1

SP 23

OP 38

K1 EMIGRATION \& immigration

K1 CLIMATIC changes

K1 ADAPTATION (Biology)

K1 CYCLONES

K1 CASE studies

K1 BANGLADESH

K1 adaptation

K1 climate change

$\mathrm{K} 1$ migration

K1 vulnerability

AB Migration in response to climate change should not be seen as a failure to adapt, but as a strategy undertaken to increase household resilience. This will, however, happen when migration is planned and supported and not under distress. This article focuses on people's movements in the aftermath of cyclone Aila. It looks at factors influencing migration in five coastal villages in Bangladesh, and their migration experience. ABSTRACT FROM AUTHOR]; Copyright of Gender \& Development is the property of Routledge and its content may not be copied or emailed to multiple sites or posted to a listserv without the copyright holder's express written permission. However, users may print, download, or email articles for individual use. This abstract may be abridged. No warranty is given about the accuracy of the copy. Users should refer to the original published version of the material for the full abstract. (Copyright applies to all Abstracts.) 
NO M3: Article

SN 13552074

AN 59362550

LK http://library.smu.ca:2048/login?http://search.ebscohost.com/login.aspx? direct $=$ true $\& \mathrm{db}=a p h \& A N=59362550 \&$ site $=$ ehost-live

DO 10.1080/13552074.2011.554017

DS EBSCO

OL Unknown(0)

RT Journal Article

SR Print(0)

ID 3141

A1 King,David

A1 Bird,Deanne

A1 Haynes, Katharine

A1 Boon, Helen

A1 Cottrell,Alison

A1 Millar,Joanne

A1 Okada,Tetsuya

A1 Box,Pamela

A1 Keogh,Diane

A1 Thomas,Melanie

T1 Voluntary relocation as an adaptation strategy to extreme weather events

JF International Journal of Disaster Risk Reduction

YR 2014

FD 6

VO 8

IS 0

SP 83

OP 90

K1 Climate change adaptation

K1 Migration

K1 Relocation

K1 Natural disasters

K1 Australia

K1 Flood

K1 Cyclone

SN 2212-4209

DO http://dx.doi.org/10.1016/j.ijdrr.2014.02.006

DS ScienceDirect

UL http://www.sciencedirect.com/science/article/pii/S2212420914000211

OL Unknown(0)

RT Journal Article

SR Print(0)

ID 836

A1 Kobayashi,Hirohide

A1 Thanh,Duc Tran

A1 Tanaka,Ueru

T1 Housing Conditions of a Lagoon Village in a Flood-prone Area of Central Vietnam JF Journal of Asian Architecture and Building Engineering

YR 2012

FD 01/01

VO 11 
IS 1

SP 79

OP 85

NO Technology (General), Building Engineering

PB Japan Science and Technology Agency

SN 1346-7581; 1347-2852

LK https://www.swetswise.com/swoc-web/link/access_db?

issn $=1347-2852 \& \mathrm{vol}=00011$ \&iss $=00001$ \&page $=79 \& \mathrm{year}=2012$

OL Unknown(0)

RT Journal Article

SR Print(0)

ID 472

A1 Kuhlicke,Christian

T1 Resilience: A capacity and a myth: Findings from an in-depth case study in disaster management research

JF Natural Hazards

JO Nat.Hazards

YR 2013

VO 67

IS 1

SP 61

K1 disaster management

K1 flood

K1 natural hazard

K1 power relations

$\mathrm{K} 1$ qualitative analysis

K1 research

$A B$ The discussion surrounding resilience to natural hazards and disasters has advanced considerably within the last years. It ranges from ecological to social systems and also covers some socio-ecological spaces in-between. Yet, although the discussion is broad and multifaceted, a common theme runs through most approaches to resilience: Resilience is defined as a system's capacity to adapt to or respond to singular, unique and most often radically surprising events. This paper seeks to shed some light on a different aspect of resilience; its constructionist dimension. For doing this, it introduces the 'myth of resilience, which not only considers the functional aspects of resilience (i. e. actors capacities), but also how actors make retrospectively sense of the radically surprising discovery of something entirely unknown. The paper will argue that the 'myth of resilience' may become a powerful worldview that enables actors to define what is 'right' and what is 'wrong', as it may be used as a very intriguing way of changing, creating and consolidating power relations; at least this is the insight a study on disaster management reveals. The case study was conducted in a municipality of a city located in the State of Saxony Germany, which was severely affected by the 2002 August flood. The paper ends with outlining implications for the discussion on resilience. \&copy; 2010 Springer Science+Business Media B.V.

PP Van Godewijckstraat 30, Dordrecht, 3311 GZ, Netherlands

SN 0921030X

LA English

LK http://dx.doi.org/10.1007/s11069-010-9646-y

DB Compilation and indexing terms, Copyright 2013 Elsevier Inc.; GEOBASE

OL Unknown(0)

RT Journal Article

SR Print(0)

ID 2036 
A1 Kunreuther,Howard

T1 Disaster Mitigation and Insurance: Learning from Katrina

JF Annals of the American Academy of Political and Social Science

JO Ann.Am.Acad.Pol.Soc.Sci.

YR 2006

FD Mar.

VO 604

IS , Shelter from the Storm: Repairing the National Emergency Management System after

Hurricane Katrina

SP 208

OP 227

AB Hurricane Katrina illustrates the natural disaster syndrome. Prior to a disaster, individuals in hazard-prone regions do not voluntarily adopt cost-effective loss reduction measures. The federal government then comes to the rescue with disaster assistance even if it claimed it had no intention of doing so prior to the event. There are a number of reasons why individuals do not protect themselves prior to a disaster. They underestimate the likelihood of a future disaster, often believing that it will not happen to them; have budget constraints; are myopic in their behavior; and/or do not want to be the only one on the block modifying their structure. Given this lack of interest in voluntary protection, benefit-cost analysis can determine when a well-enforced building code would be appropriate. The article concludes by highlighting the importance of public-private partnerships as a way of reducing future disaster losses and aiding the recovery process.

PB Sage Publications, Inc. in association with the American Academy of Political and Social Science

SN 00027162

LA English

SF research-article; Copyright (C) 2006 American Academy of Political and Social Science LK http://www.jstor.org/stable/25097789

DS JSTOR

OL Unknown(0)

RT Journal Article

SR Print(0)

ID 2051

A1 Kweit,Mary Grisez

A1 Kweit,Robert W.

T1 A Tale of Two Disasters

JF Publius

YR 2006

FD Summer

VO 36

IS 3, The State of American Federalism, 2005-2006

SP 375

OP 392

AB The report to the U.S. president entitled The Federal Response to Hurricane Katrina concludes that in the event of catastrophic disasters the traditional intergovernmental response to disaster should give way to a more dominant role of the national government. This article considers whether it is possible to respond effectively to disaster in the traditional, intergovernmental mode by comparing the response to Katrina with the response, which was widely considered to be successful, to another disaster, in Grand Forks, North Dakota. The research suggests that an intergovernmental response can be successful if those who respond to the disaster interact in a collaborative network. The article considers whether such collaborative networks can be created and evaluates some of the recommendations from The Federal Response to Hurricane Katrina as potentially helping to create collaborative networks. 
PB Oxford University Press

SN 00485950

LA English

SF research-article; Copyright (C) 2006 CSF Associates Inc.

LK http://www.jstor.org/stable/4624754

DS JSTOR

OL Unknown(0)

RT Journal Article

SR Print(0)

ID 2110

A1 Kysar,Douglas A.

A1 McGarity,Thomas O.

T1 Did Nepa Drown New Orleans? The Levees, the Blame Game, and the Hazards of Hindsight JF Duke law journal

JO Duke Law J.

YR 2006

FD Oct.

VO 56

IS 1, Thirty-Sixth Annual Administrative Law Issue

SP 179

OP 235

$A B$ This Article highlights the hazards of hindsight analysis of the causes of catastrophic events, focusing on theories of why the New Orleans levees failed during Hurricane Katrina in 2005 and particularly on the theory that the levee failures were "caused" by a 1977 National Environmental Policy Act (NEPA) lawsuit that resulted in a temporary injunction against the Army Corps of Engineers' hurricane protection project for New Orleans. The Article provides a detailed historical reconstruction of the decision process that eventuated in the New Orleans storm surge protection system, focusing both on the political and legal factors involved and on the "standard project hurricane" risk assessment model that lay at the heart of the Army Corps of Engineers' decisionmaking process. The Article then offers a detailed analysis of how and why Hurricane Katrina overcame the New Orleans levee system. As this analysis demonstrates, the argument that the NEPA lawsuit played a meaningful causal role in the Katrina disaster is not persuasive. Parallel lessons are then drawn for forward-looking disaster policy. The same problems of uncertainty and complexity that confound the attempt through hindsight to attribute causal responsibility for a disaster also confound the attempt to predict using foresight the variety of outcomes, including potentially disastrous ones, that may flow from policy choices. Focusing narrowly on any single parameter of complex natural and human systems is likely to dramatically distort environmental health, and safety decisionmaking, whether the parameter is a "standard project hurricane" when planning a hurricane protection plan, or the equally mythical "lawsuit that sunk New Orleans" when attempting to allocate responsibility for the plan's failure some forty years later.

PB Duke University School of Law

SN 00127086

LA English

SF research-article; Copyright (C) 2006 Duke University School of Law

LK http://www.jstor.org/stable/40040543

DS JSTOR

OL Unknown(0)

RT Journal Article

SR Print(0)

ID 1520

A1 Larsen,Rasmus Klocker 
A1 Calgaro,Emma

A1 Thomalla,Frank

T1 Governing resilience building in Thailand's tourism-dependent coastal communities:

Conceptualising stakeholder agency in social-ecological systems

JF Global Environmental Change Part A: Human \& Policy Dimensions

YR 2011

FD 05

VO 21

IS 2

SP 481

OP 491

K1 ENVIRONMENTAL sociology

K1 COASTAL ecology

K1 HAZARDS

K1 TRAVEL

K1 STAKEHOLDERS

K1 RESILIENCE (Personality trait)

K1 THEORY of knowledge

K1 THAILAND

AB Abstract: In current scientific efforts to harness complementarity between resilience and vulnerability theory, one response is an 'epistemological shift' towards an evolutionary, learning based conception of the 'systems-actor' relation in social-ecological systems. In this paper, we contribute to this movement regarding the conception of stakeholder agency within socialecological systems. We examine primary evidence from the governance of post-disaster recovery and disaster risk reduction efforts in Thailand"'s coastal tourism-dependent communities following the 2004 Indian Ocean Tsunami. Through an emerging storyline from stakeholders, we construct a new framework for conceptualising stakeholder agency in socialecological systems, which positions the notion of resilience within a conception of governance as a negotiated normative process. We conclude that if resilience theory is proposed as the preferred approach by which disaster risk reduction is framed and implemented, it needs to acknowledge much more explicitly the role of stakeholder agency and the processes through which legitimate visions of resilience are generated. Copyright \&y\& Elsevier]; Copyright of Global Environmental Change Part A: Human \& Policy Dimensions is the property of Pergamon Press - An Imprint of Elsevier Science and its content may not be copied or emailed to multiple sites or posted to a listserv without the copyright holder's express written permission. However, users may print, download, or email articles for individual use. This abstract may be abridged. No warranty is given about the accuracy of the copy. Users should refer to the original published version of the material for the full abstract. (Copyright applies to all Abstracts.)

NO M3: Article

SN 09593780

AN 60787394

LK http://library.smu.ca:2048/login?http://search.ebscohost.com/login.aspx? direct=true \&db=8gh\&AN=60787394\&site=ehost-live

DO 10.1016/j.gloenvcha.2010.12.009

DS EBSCO

OL Unknown(0)

RT Journal Article

SR Print(0)

ID 1119

A1 Lee,Matthew R.

A1 Blanchard, Troy C. 
T1 Community Attachment and Negative Affective States in the Context of the BP Deepwater Horizon Disaster

JF American Behavioral Scientist

JO Am.Behav.Sci.

YR 2012

FD 01

VO 56

IS 1

SP 24

OP 47

K1 DISASTERS -- Psychological aspects

K1 COMMUNITIES

K1 ANXIETY

K1 FEAR

K1 BP Deepwater Horizon Explosion \& Oil Spill, 2010

K1 LOUISIANA

K1 community attachment

K1 disaster

K1 mental health

K1 stress

$\mathrm{K} 1$ technological disaster

AB This study advances research on the mental health impacts of disasters by examining how a mainstay of the sociological literature, community attachment, influences negative affective states such as anxiety and fear stimulated by a technological disaster. Survey data were collected in three coastal Louisiana parishes (counties) geographically proximate to the BP oil spill of 2010 while the oil was still flowing. The data reveal that community attachment is associated with higher levels of negative affect. This finding holds for those tied to the fishing and seafood industry, those tied to the oil industry, and those having no immediate links to either industry. These results highlight that although community attachment is essential for community resilience, it can also be disruptive to individual well-being when technological disasters occur in communities dependent on renewable and natural resources. ABSTRACT FROM PUBLISHER]; Copyright of American Behavioral Scientist is the property of Sage Publications Inc. and its content may not be copied or emailed to multiple sites or posted to a listserv without the copyright holder's express written permission. However, users may print, download, or email articles for individual use. This abstract may be abridged. No warranty is given about the accuracy of the copy. Users should refer to the original published version of the material for the full abstract. (Copyright applies to all Abstracts.)

NO M3: Article

SN 00027642

AN 70286660

LK http://library.smu.ca:2048/login?http://search.ebscohost.com/login.aspx?

direct $=$ true $\& \mathrm{db}=a$ ph $\& A N=70286660 \&$ site=ehost-live

DO 10.1177/0002764211409384

DS EBSCO

OL Unknown(0)

RT Journal Article

SR Print(0)

ID 349

A1 Lewis,James

T1 Some realities of resilience: an updated case study of storms and flooding at Chiswell, Dorset

JF Disaster Prevention \& Management

YR 2013 
FD 10

VO 22

IS 4

SP 300

OP 311

K1 GEOMORPHOLOGY

K1 PHYSICAL geography

K1 HUMAN ecology

K1 STORMS

K1 FLOODS

K1 CASE studies

K1 Aftercare

K1 Chiswell

K1 Resilience

K1 Vulnerability

AB Purpose - The purpose of this paper is to reassess Chiswell's vulnerability to storm and sea flooding since an analysis made in 1979 and to identify characteristics of resilience, a more recent item of disaster studies terminology. Design/methodology/approach - Chiswell's geography, geomorphology and changes affecting its vulnerability up to 1979, are described against its history of storms. Two serious storms in 1978 and 1979 drew attention to Chiswell's need of improved protection and a flood alleviation scheme was completed. Some consequences for Chiswell of the completed scheme are described and considered in relation to climate change, Chiswell's inclusion in the UNESCO Jurassic Coast and its expression of human ecology in a context of natural hazards of the sea. Findings - Resilience existed before its inclusion in the terminology of disaster studies. The role of a community pressure group and of local and national administrations are considered against the timescale of protection provision. The essential requirement of external inputs before community resilience became evident is highlighted, together with additional observed and itemised characteristics of resilience. Research limitations/implications - Updated research is based upon the results of rapid field observation and extensive use of internet sources, not available in 1979. Practical implications - Realities of resilience may assist interpretation of its theoretical evaluations and expectations. Originality/value - As yet, there are few field evaluations of resilience. ABSTRACT FROM AUTHOR]; Copyright of Disaster Prevention \& Management is the property of Emerald Group Publishing Limited and its content may not be copied or emailed to multiple sites or posted to a listserv without the copyright holder's express written permission. However, users may print, download, or email articles for individual use. This abstract may be abridged. No warranty is given about the accuracy of the copy. Users should refer to the original published version of the material for the full abstract. (Copyright applies to all Abstracts.)

NO TY: CASE; M3: Case Study

SN 09653562

AN 90610964

LK C:IUsers\s9130263\Documents\Cases\Lewis_2013_UK.pdf

DO 10.1108/DPM-03-2013-0053

DS EBSCO

OL Unknown(0)

RT Journal Article

SR Print(0)

ID 1649

A1 Linda Anderson-Berry

A1 David King

T1 Mitigation of the Impact of Tropical Cyclones in Northern Australia through Community Capacity Enhancement

JF Mitigation \& Adaptation Strategies for Global Change 
YR 2005

FD 07

VO 10

IS 3

SP 367

OP 392

K1 CYCLONES

K1 HAZARD mitigation

K1 EMERGENCY management

K1 TROPICS

K1 AUSTRALIA, Northern

$A B$ Community mitigation of hazard impact requires hazard knowledge and preparedness on the part of the members of diverse and complex communities. Longitudinal research in the tropical cyclone prone north of Australia has gathered extensive datasets on community awareness, preparedness and knowledge, in order to contribute to education campaigns and mitigation strategies. Data have been used to identify issues of vulnerability to cyclones and capacity to deal with the hazard. This has been developed as a community vulnerability and capacity model that may be applied to diverse communities in order to assess levels of capability to mitigate and deal with the cyclone hazard. The model is presented here in a simplified form as its development is evolving and ongoing. ABSTRACT FROM AUTHOR]; Copyright of Mitigation \& Adaptation Strategies for Global Change is the property of Springer Science \& Business Media B.V. and its content may not be copied or emailed to multiple sites or posted to a listserv without the copyright holder's express written permission. However, users may print, download, or email articles for individual use. This abstract may be abridged. No warranty is given about the accuracy of the copy. Users should refer to the original published version of the material for the full abstract. (Copyright applies to all Abstracts.) NO M3: Article

SN 13812386

AN 20390662

LK http://library.smu.ca:2048/login?http://search.ebscohost.com/login.aspx? direct=true $\& \mathrm{db}=8 \mathrm{gh} \& A \mathrm{~N}=20390662 \&$ site=ehost-live

DS EBSCO

OL Unknown(0)

RT Journal Article

SR Print(0)

ID 288

A1 Liu,Lixiong

A1 Lin,Yanliu

A1 Wang,Shifu

T1 Urban design for post-earthquake reconstruction: A case study of Wenchuan County, China JF Habitat International

YR 2014

FD 01

VO 41

SP 290

OP 299

K1 URBAN planning

K1 WENCHUAN Earthquake, China, 2008

K1 BUILDINGS -- Repair \& reconstruction

K1 BUILDINGS -- Safety measures

K1 PUBLIC spaces

K1 CASE study (Research) 
AB Abstract: Urban design for post-earthquake reconstruction emphasizes strategies, safety, memorials and institutional arrangements. It is closely related to earthquake recovery plans.

This article reviews general studies on urban design for post-earthquake reconstruction, before focussing on the case of Weizhou Town in Wenchuan County, which in 2008 was severely damaged by a magnitude-8 earthquake. Unique institutional arrangements, however, led to a rapid recovery and reconstruction process. The urban design for post-earthquake

reconstruction in Weizhou Town was an integrated approach that promoted both long-term and short-term developments and combined the creation of public space with the provision of public facilities. It created four interwoven systems, namely a safety system, a memorial system, a tourism system and a network of open spaces. This study shows that the urban design for post-earthquake reconstruction in Weizhou Town greatly improved the safety and vibrancy of the town, whereas the top-down approach and the rapid reconstruction process resulted in new problems. Copyright \&y\& Elsevier]; Copyright of Habitat International is the property of Pergamon Press - An Imprint of Elsevier Science and its content may not be copied or emailed to multiple sites or posted to a listserv without the copyright holder's express written permission. However, users may print, download, or email articles for individual use. This abstract may be abridged. No warranty is given about the accuracy of the copy. Users should refer to the original published version of the material for the full abstract. (Copyright applies to all Abstracts.)

NO M3: Article

SN 01973975

AN 91969587

LK C:\Users\s9130263\Documents\Cases\Liu_etal_2014.pdf

DO 10.1016/j.habitatint.2013.09.001

DS EBSCO

OL Unknown(0)

RT Journal Article

SR Print(0)

ID 1573

A1 López-Marrero,Tania

A1 Tschakert,Petra

T1 From theory to practice: building more resilient communities in flood-prone areas

JF Environment \& Urbanization

YR 2011

FD 04

VO 23

IS 1

SP 229

OP 249

K1 FLOOD damage prevention

K1 FLOOD control

K1 URBAN planning

K1 SOCIAL aspects

K1 COMMUNITY involvement

K1 SOCIAL learning

K1 RESILIENCE (Personality trait) -- Social aspects

K1 flood management

K1 floods

K1 participatory methods

K1 Puerto Rico

$\mathrm{K} 1$ resilience

$A B$ Enhancing community resilience is key to reducing vulnerability in the face of natural hazards. In this article, we discuss the elements that support or undermine community 
resilience to floods and propose ways of enhancing it. In the study, participatory methods and techniques were used with community members and emergency managers from a flood-prone municipality of Puerto Rico, including conceptual mapping, participatory mapping, and listing and ranking. The findings suggest that enhancing resilience in these communities requires: support for social learning by building on existing knowledge; stressing the importance of developing a diverse set of flood management options; and promoting effective linkages and collaborations between community members and emergency managers to encourage collective flood management. For this to happen, however, mutual distrust, lack of confidence and other obstacles must be overcome. ABSTRACT FROM PUBLISHER]; Copyright of Environment \& Urbanization is the property of Sage Publications, Ltd. and its content may not be copied or emailed to multiple sites or posted to a listserv without the copyright holder's express written permission. However, users may print, download, or email articles for individual use. This abstract may be abridged. No warranty is given about the accuracy of the copy. Users should refer to the original published version of the material for the full abstract. (Copyright applies to all Abstracts.)

NO M3: Article

SN 09562478

AN 60094764

LK file://C:/Users/s9130263/Documents/Cases/Lopez-Marrero_\&_Tschakert_2011.pdf

DO 10.1177/0956247810396055

DS EBSCO

OL Unknown(0)

RT Journal Article

SR Print(0)

ID 554

A1 Lopez-Marrero,Tania

T1 An integrative approach to study and promote natural hazards adaptive capacity: A case study of two flood-prone communities in Puerto Rico

JF Geographical Journal

JO Geogr.J.

YR 2010

VO 176

IS 2

SP 150

$\mathrm{K} 1$ adaptive management

K1 flood

K1 flood control

$\mathrm{K} 1$ hazard assessment

$\mathrm{K} 1$ natural hazard

$\mathrm{K} 1$ risk assessment

$\mathrm{K} 1$ risk perception

K1 social impact

K1 social security

$\mathrm{K} 1$ vulnerability

$\mathrm{AB}$ The risk and vulnerability literature emphasises the importance of increasing the adaptive capacity to natural hazards of exposed populations. This paper analyses the strategies of adjustment implemented by members of two flood-prone communities in Puerto Rico, and discusses how the adoption of these strategies and other factors could influence future adaptive capacity and vulnerability to floods. Semi-structured interviews with community members from different resource endowment groups were used to elicit the resources behind the process of adjustment along with additional factors that could influence future adaptive capacity, including their perceptions of risks related to floods. The analysis revealed how access to resources - including material, economic and human resources - has facilitated living 
with floods in these communities; although not everyone has been able to adapt in the same way. Past actions, along with public responses being undertaken in the area (i.e. flood control project and upstream structural modifications) appear to be reducing flood-risk perceptions and promoting a false sense of security among community members, irrespective of resource endowment group. For that reason, developing ways to increase awareness about future flood potential and making clear the need for complementary non-structural strategies is imperative. In short, the research findings emphasise that access to resources and cognitive factors are important determinants of adaptive capacity. Hence, both should be taken into account while developing practical strategies towards increasing adaptive capacity and reducing vulnerability to floods specifically, and to other natural hazards in general. \&copy; 2010 The Author(s). Journal compilation \&copy; 2010 The Royal Geographical Society.

PP 9600 Garsington Road, Oxford, OX4 2XG, United Kingdom

SN 00167398

LA English

LK http://dx.doi.org/10.1111/j.1475-4959.2010.00353.x

DB Compilation and indexing terms, Copyright 2013 Elsevier Inc.; GEOBASE

OL Unknown(0)

RT Journal Article

SR Print(0)

ID 1628

A1 Mahmud,Tanvir

A1 Prowse, Martin

T1 Corruption in cyclone preparedness and relief efforts in coastal Bangladesh: Lessons for climate adaptation?

JF Global Environmental Change Part A: Human \& Policy Dimensions

YR 2012

FD 10

VO 22

IS 4

SP 933

OP 943

K1 CYCLONES

$\mathrm{K} 1 \mathrm{COASTS}$

K1 ADAPTATION (Biology)

K1 CORRUPTION

K1 PREPAREDNESS

K1 DISASTERS

K1 FOOD relief

K1 BANGLADESH

AB Abstract: This article seeks to draw possible lessons for adaptation programmes in

Bangladesh by examining whether cyclone preparedness and relief interventions are subject to corrupt practices. Based on a random sample survey of 278 households, three focus-group discussions and seven key-informant interviews, the article investigates the nature and extent of corruption in pre- and post-disaster interventions in Khulna before and after Cyclone Aila in May 2009. Ninety nine percent of households reported losses from corrupt practices. Postdisaster interventions (such as food aid and public works schemes) suffered from greater levels, and worse types, of corruption than pre-disaster interventions (such as cyclone warning systems and disaster-preparedness training). Using an asset index created using principal component analysis, the article assesses how corruption affected wealth quartiles. Ultra-poor households were affected more by corruption in pre-disaster interventions, the wealthiest quartile more in certain post-disaster interventions, in particular public works and nongovernmental interventions. These findings may hold lessons for attempts to increase resilience as current adaptation measures mirror some cyclone preparedness and relief efforts. 
Copyright \&y\& Elsevier]; Copyright of Global Environmental Change Part A: Human \& Policy Dimensions is the property of Pergamon Press - An Imprint of Elsevier Science and its content may not be copied or emailed to multiple sites or posted to a listserv without the copyright holder's express written permission. However, users may print, download, or email articles for individual use. This abstract may be abridged. No warranty is given about the accuracy of the copy. Users should refer to the original published version of the material for the full abstract. (Copyright applies to all Abstracts.)

NO M3: Article

SN 09593780

AN 79960311

LK http://library.smu.ca:2048/login?http://search.ebscohost.com/login.aspx?

direct $=$ true $\& d b=8 g h \& A N=79960311 \&$ site=ehost-live

DO 10.1016/j.gloenvcha.2012.07.003

DS EBSCO

OL Unknown(0)

RT Journal Article

SR Print(0)

ID 408

A1 Maldonado, Julie

A1 Shearer,Christine

A1 Bronen, Robin

A1 Peterson, Kristina

A1 Lazrus, Heather

T1 The impact of climate change on tribal communities in the US: displacement, relocation, and human rights

JF Climatic Change

JO Clim.Change

YR 2013

FD 10

VO 120

IS 3

SP 601

OP 614

K1 SEA level

K1 CLIMATIC changes

K1 ATMOSPHERE -- Research

K1 NATURAL resources -- Management

K1 LAND settlement

K1 RECESSIONS -- United States

AB Tribal communities in the United States, particularly in coastal areas, are being forced to relocate due to accelerated rates of sea level rise, land erosion, and/or permafrost thaw brought on by climate change. Forced relocation and inadequate governance mechanisms and budgets to address climate change and support adaptation strategies may cause loss of community and culture, health impacts, and economic decline, further exacerbating tribal impoverishment and injustice. Sovereign tribal communities around the US, however, are using creative strategies to counter these losses. Taking a human rights approach, this article looks at communities' advocacy efforts and strategies in dealing with climate change, displacement, and relocation. Case studies of Coastal Alaska and Louisiana are included to consider how communities are shaping their own relocation efforts in line with their cultural practices and values. The article concludes with recommendations on steps for moving forward toward community-led and government-supported resettlement programs. ABSTRACT FROM AUTHOR]; Copyright of Climatic Change is the property of Springer Science \& Business Media B.V. and its content may not be copied or emailed to multiple sites or posted to a listserv 
without the copyright holder's express written permission. However, users may print, download, or email articles for individual use. This abstract may be abridged. No warranty is given about the accuracy of the copy. Users should refer to the original published version of the material for the full abstract. (Copyright applies to all Abstracts.)

NO M3: Article

SN 01650009

AN 90187319

LK http://library.smu.ca:2048/login?http://search.ebscohost.com/login.aspx?

direct $=$ true $\& \mathrm{db}=8 \mathrm{gh} \& A \mathrm{~N}=90187319 \&$ site $=$ ehost-live

DO 10.1007/s10584-013-0746-z

DS EBSCO

OL Unknown(0)

RT Journal Article

SR Print(0)

ID 1626

A1 Mallick,Bishawjit

A1 Rahaman,Khan

A1 Vogt,Joachim

T1 Coastal livelihood and physical infrastructure in Bangladesh after cyclone Aila

JF Mitigation \& Adaptation Strategies for Global Change

YR 2011

FD 06

VO 16

IS 6

SP 629

OP 648

K1 CLIMATIC changes -- Environmental aspects

K1 CYCLONES

K1 EMERGENCY management

K1 COASTAL ecology

K1 ECONOMIC aspects

K1 INFRASTRUCTURE (Economics)

$\mathrm{K} 1$ SOCIAL surveys

K1 BANGLADESH

K1 Coastal

$\mathrm{K} 1$ Cyclone

K1 Infrastructure

K1 Livelihood

$A B$ This paper aimed at to explore the consequences of cyclone victims due to unavailability of infrastructural supports and to prop up the recognition that the infrastructure has a vital role to play in societies' resilience during catastrophic situation. The paper begins with a review of the science regarding climate change impact and cyclone disaster in Bangladesh. It emphasizes the consequences of cyclone Aila in a selected coastal community in the remote coastal area. A field survey was conducted by authors during March-August 2009. Eight available infrastructures were selected for this analysis. Uniformity of distribution (R), demand index (Di) and degree of demand (DD) of the selected infrastructures were calculated by using nearest neighbourhood methods of analysis. Results show that based on its specific planning standards none of the selected infrastructure can support $50 \%$ of the total population. Accordingly, it was observed that $76 \%$ respondent could not reach in safer place due to rush of water intrusion and also because of the inundation of road-network. The nearness to the available cyclone shelter, and place of taking shelter during cyclone is positively correlated $(r=$ 0.38; $p<0.001$ ). However, the poor people had less opportunity to take shelter in cyclone shelters, although none of the respondents groups whose monthly income is above 75 USD 
stands without any infrastructural support. Such important observation may hint the influence of local elites on the local disaster mitigation planning practice in Bangladesh. Almost $90 \%$ of the respondents claimed that they had no access to enter the available cyclone shelter. Furthermore, the damaged infrastructures added more hindrances during post disaster activities and also increased the sufferings of the victims. If there were adequate cyclone shelters or rehabilitation centre, the affected people could take shelter and continue other works temporarily. Results drawn from this research will be useful for local and national level planners, as well as international donors for future disaster mitigation planning in the studied area and the methodology can be applied in similar countries and geographical territories. ABSTRACT FROM AUTHOR]; Copyright of Mitigation \& Adaptation Strategies for Global Change is the property of Springer Science \& Business Media B.V. and its content may not be copied or emailed to multiple sites or posted to a listserv without the copyright holder's express written permission. However, users may print, download, or email articles for individual use. This abstract may be abridged. No warranty is given about the accuracy of the copy. Users should refer to the original published version of the material for the full abstract. (Copyright applies to all Abstracts.)

NO M3: Article

SN 13812386

AN 62519264

LK http://library.smu.ca:2048/login?http://search.ebscohost.com/login.aspx?

direct=true \&db=8gh\&AN=62519264\&site=ehost-live

DO 10.1007/s11027-011-9285-y

DS EBSCO

OL Unknown(0)

RT Journal Article

SR Print(0)

ID 846

A1 Mallick,Bishawjit

A1 Vogt,Joachim

T1 Cyclone, coastal society and migration: empirical evidence from Bangladesh

JF International Development Planning Review

YR 2012

FD 01/01

VO 34

IS 3

SP 217

OP 240

NO General Legislative \& Exec., International Relations

PB Liverpool University Press - Turpin Distribut

SN 1474-6743; 1478-3401

LK https://www.swetswise.com/swoc-web/link/access_db?

issn $=1478-3401 \& \mathrm{vol}=00034 \&$ iss $=00003 \&$ page $=217 \&$ year $=2012$

OL Unknown(0)

RT Journal Article

SR Print(0)

ID 166

A1 Mamun,M. Z.

T1 Awareness, preparedness and adjustment measures of river-bank erosion-prone people: a case study

JF Disasters

JO Disasters

YR 1996 
VO 20

IS 1

SP 68

K1 agricultural impact

K1 flood mitigation

K1 flooding

K1 hazard losses

AB Communities' lack of success in combating erosion can be attributed to their poverty and to their not knowing about any means to mitigate its effects. Households in safer areas have reduced their dependence on agriculture and developed more scope for non-farm activities, however, this is often difficult given the limited development of local enterprise. The major parameters that influence the adjustment measures after erosion are the education, skills, occupation and financial state of those affected. Those most vulnerable are households very much dependent on agriculture: for them resettlement to distant urban areas is not an option. from Author

SN 03613666

LA English

DB Compilation and indexing terms, Copyright 2013 Elsevier Inc.; GEOBASE

OL Unknown(0)

RT Journal Article

SR Print(0)

ID 2525

A1 Marcillia,Syam Rachma

A1 Ohno,Ryuzo

T1 Learning from Resident's Adjustments in Self-built and Donated Post Disaster Housing after Java Earthquake 2006

JF Procedia - Social and Behavioral Sciences

YR 2012

VO 36

IS 0

SP 61

OP 69

K1 Self-built housing

$\mathrm{K} 1$ donated housing

$\mathrm{K} 1$ lifestyle

$\mathrm{K} 1$ social interaction

$\mathrm{K} 1$ adjustments

T2 ASEAN Conference on Environment-Behaviour Studies (AcE-Bs), Savoy Homann Bidakara Hotel, 15-17 June 2011, Bandung, Indonesia

SN 1877-0428

DO http://dx.doi.org/10.1016/j.sbspro.2012.03.007

DS ScienceDirect

UL http://www.sciencedirect.com/science/article/pii/S1877042812004740

OL Unknown(0)

RT Journal Article

SR Print(0)

ID 1023

A1 Marfai,Muh Aris

A1 Hizbaron,Dyah R.

T1 Community's Adaptive Capacity due to Coastal Flooding in Semarang Coastal City, Indonesia 
JF Annals of the University of Oradea, Geography Series / Analele Universitatii din Oradea, Seria Geografie

YR 2011

FD 12

VO 21

IS 2

SP 219

OP 221

K1 EMERGENCY management

K1 FLOODS

K1 COMMUNITIES

K1 SEMARANG (Indonesia)

K1 INDONESIA

$\mathrm{K} 1$ coastal area

$\mathrm{K} 1$ community's response and adaptive capacity

K1 Semarang City

K1 Terboyo Wetan and Trimulyo Villages

$\mathrm{K} 1$ tidal flood hazard

AB Community's response and adaptive capacity is a one of the key roles on the disaster management and risk reduction program. This study is aimed to investigate the coastal community's response and adaptive capacity due to tidal flood hazard in the Terboyo Wetan Village and Trimulyo Villages along the coastline of Semarang City. These two villages are suffered from tidal flood hazards, and further consequences are land subsidence hazards as the impact of man-made activity and worsened by industrial activity. The research is inductively attaining data and concluding the result as in a descriptive manner via questionnaire. The result reveals that the local communities are aware of the tidal flood hazard, but this understanding did not manage to support their decision to leave the area. The community has adapted the tidal flood by simple physical adaptation strategy, such as increase the floor level following the water level and making small dam to blocking water enter the house. This response is not sufficient and aesthetically not proper from the environmental point of view. From the community's perception obtained during the research, it can be said that instead of taking the tidal flood as the risk, the community in the research area tends to neglect the hazard and considered that the tidal flood is no longer as threat towards their wellbeing. ABSTRACT FROM AUTHOR]; Copyright of Annals of the University of Oradea, Geography Series / Analele Universitatii din Oradea, Seria Geografie is the property of University of Oradea, Department of Geography, Tourism \& Territorial Planning and its content may not be copied or emailed to multiple sites or posted to a listserv without the copyright holder's express written permission. However, users may print, download, or email articles for individual use. This abstract may be abridged. No warranty is given about the accuracy of the copy. Users should refer to the original published version of the material for the full abstract. (Copyright applies to all Abstracts.)

NO M3: Article

PB University of Oradea, Department of Geography, Tourism \& Territorial Planning

SN 12211273

AN 77882898

LK http://library.smu.ca:2048/login?http://search.ebscohost.com/login.aspx?

direct=true\&db=aph\&AN=77882898\&site=ehost-live

DS EBSCO

OL Unknown(0)

RT Journal Article

SR Print(0)

ID 1482

A1 Marfai,Muh Aris 
A1 King,Lorenz

A1 Sartohadi,Junun

A1 Sudrajat,Sudrajat

A1 Budiani,Sri Rahayu

A1 Yulianto,Fajar

T1 The impact of tidal flooding on a coastal community in Semarang, Indonesia

JF Environmentalist

JO Environmentalist

YR 2008

FD 09

VO 28

IS 3

SP 237

OP 248

K1 FLOODS

K1 FLOOD damage

K1 ENVIRONMENTAL management

K1 NATURAL disasters

K1 SEMARANG (Indonesia)

K1 INDONESIA

K1 Community and government's response

$\mathrm{K} 1$ Community and government's response

K1 Semarang

K1 Tidal flood impact

AB The article presents household vulnerability, local community adaptive capacity, and government's response to tidal flood hazard in the Semarang coastal area, Central Java Province, Indonesia. Using data gathered from a survey of households, the study revealed a number of important factors about the interaction between people and flood. The coastal community has been experiencing problems related to tidal floods. They have adapted to tidal flooding with structural measures, such as increasing the floor level, making small dams in front of houses, increasing yard and street levels in the neighborhood area, and creating dykes around residential areas. Tidal flood mitigation in the Semarang coastal area should incorporate governmental action and local community capacities for proper protection of the population. ABSTRACT FROM AUTHOR]; Copyright of Environmentalist is the property of Springer Science \& Business Media B.V. and its content may not be copied or emailed to multiple sites or posted to a listserv without the copyright holder's express written permission. However, users may print, download, or email articles for individual use. This abstract may be abridged. No warranty is given about the accuracy of the copy. Users should refer to the original published version of the material for the full abstract. (Copyright applies to all Abstracts.) NO M3: Article

SN 02511088

AN 34949264

LK http://library.smu.ca:2048/login?http://search.ebscohost.com/login.aspx? direct $=$ true $\& \mathrm{db}=8 \mathrm{gh} \& A \mathrm{~N}=34949264 \&$ site $=$ ehost-live

DO 10.1007/s10669-007-9134-4

DS EBSCO

OL Unknown(0)

RT Journal Article

SR Print(0)

ID 2489

A1 Marín,Andrés

A1 Gelcich,Stefan

A1 Araya,Gonzalo 
A1 Olea,Gonzalo

A1 Espíndola,Miguel

A1 Castilla,Juan C.

T1 The 2010 tsunami in Chile: Devastation and survival of coastal small-scale fishing

communities

JF Marine Policy

JO Mar.Policy

YR 2010

FD 11

VO 34

IS 6

SP 1381

OP 1384

K1 Artisanal fishers

K1 Coastal communities

K1 Hazards

K1 Human dimensions

K1 Natural disaster

K1 Perceptions

SN 0308-597X

DO http://dx.doi.org/10.1016/j.marpol.2010.06.010

DS ScienceDirect

UL http://www.sciencedirect.com/science/article/pii/S0308597X10001168

OL Unknown(0)

RT Journal Article

SR Print(0)

ID 1326

A1 Mary Mellor

A1 Carol Stephenson

T1 The Durham Miners' Gala and the spirit of community

JF Community Development Journal

JO Community Dev.J.

YR 2005

FD 07

VO 40

IS 3

SP 343

OP 351

K1 SOCIAL groups

K1 LABOR supply

K1 MINERAL industries

K1 MANPOWER

AB Can industrial communities survive the loss of their industrial heritage? Can communities once thought to be in terminal decline reinvigorate themselves? Evidence from the Durham coalmining communities suggests that the answer to both questions is yes. This paper presents evidence from a study of the annual Durham Miners' Gala - the 'Big Meeting' - that reflects a revival of community vitality around the event. Together with an analysis of the Gala itself, the complex background to the resilience of the mining communities is explored. ABSTRACT FROM AUTHOR]; Copyright of Community Development Journal is the property of Oxford University Press / USA and its content may not be copied or emailed to multiple sites or posted to a listserv without the copyright holder's express written permission. However, users may print, download, or email articles for individual use. This abstract may be abridged. No 
warranty is given about the accuracy of the copy. Users should refer to the original published version of the material for the full abstract. (Copyright applies to all Abstracts.)

NO M3: Article

SN 00103802

AN 20169670

LK http://library.smu.ca:2048/login?http://search.ebscohost.com/login.aspx?

direct=true\&db=aph\&AN=20169670\&site=ehost-live

DS EBSCO

OL Unknown(0)

RT Journal Article

SR Print(0)

ID 159

A1 Masozera, Michel

A1 Bailey,Melissa

A1 Kerchner,Charles

T1 Distribution of impacts of natural disasters across income groups: A case study of New

Orleans

JF Ecological Economics

JO Ecol.Econ.

YR 2007

VO 63

IS 2-3

SP 299

K1 disaster management

$\mathrm{K} 1$ flood damage

K1 future prospect

K1 GIS

K1 Hurricane Katrina 2005

$\mathrm{K} 1$ natural disaster

K1 socioeconomic conditions

K1 vulnerability

AB This paper explores elements of vulnerability to natural disasters in the context of Hurricane

Katrina. We examine whether neighborhoods in New Orleans were impacted differently by Hurricane Katrina based on pre-existing social, physical and economic vulnerabilities. We evaluate the degree to which the initial impacts of Hurricane Katrina were distributed among the New Orleans' residents. Geographic Information System (GIS) technology was used to perform analyses using household income, housing values, and elevation and flood levels. Next, we investigate whether particular socio-economic groups in the city were more vulnerable during the response and recovery phases. Findings indicate that Hurricane Katrina caused severe flood damages in the majority of New Orleans neighborhoods, regardless of income, elevation and other social factors. However, findings do suggest that pre-existing socio-economic conditions play a significant role in the ability for particular economic classes to respond immediately to the disaster and to cope with the aftermath of Hurricane Katrina. The paper concludes with policy recommendations to reduce social and economic vulnerabilities to natural disasters, as well as suggestions for future research. \&copy; 2006 Elsevier B.V. All rights reserved.

SN 09218009

LA English

LK file:///C:/Users/s9130263/Documents/Cases/Masozera_etal_2007.pdf;

DB Compilation and indexing terms, Copyright 2013 Elsevier Inc.; GEOBASE

OL Unknown(0)

RT Journal Article 
SR Print(0)

ID 613

A1 Matanle,Peter

T1 Post-disaster recovery in ageing and declining communities: The Great East Japan disaster of 11 March 2011

JF Geography

JO Geography

YR 2013

VO 98

IS 2

SP 68

$\mathrm{K} 1$ disaster management

$\mathrm{K} 1$ nuclear explosion

$\mathrm{K} 1$ planning process

K1 reconstruction

K1 Tohoku earthquake 2011

$\mathrm{K} 1$ tsunami event

AB The earthquake, tsunami and nuclear meltdown that occurred in Japans north-eastern To\&macr;hoku region on 11 March 2011 has become known as the Great East Japan Disaster, and represents the most serious emergency to have been faced by the Japanese people since the end of the Second World War. More than two years have elapsed since the disaster and a clearer picture of the recovery process is now emerging. This article presents case studies of two of the settlements that experienced the full force of the tsunami by describing and analysing reconstruction planning in a region that had a rapidly ageing and shrinking population prior to 2011. After describing differences in the settlements experience of the disaster according to their physical and human geographies, the article then analyses postdisaster reconstruction plans. Although plans show commendable ambition in seeking to rebuild shattered communities, there is a danger of creating unrealistic expectations in settlements where ageing and depopulation processes appear to be accelerating. \&copy; Geography 2013.

PP 160 Solly Street, Sheffield, S1 4BF, United Kingdom

SN 00167487

LA English

DB Compilation and indexing terms, Copyright 2013 Elsevier Inc.; GEOBASE

OL Unknown(0)

RT Journal Article

SR Print(0)

ID 2561

A1 Mavhura,Emmanuel

A1 Manyena,Siambabala Bernard

A1 Collins,Andrew E.

A1 Manatsa,Desmond

T1 Indigenous knowledge, coping strategies and resilience to floods in Muzarabani, Zimbabwe JF International Journal of Disaster Risk Reduction

YR 2013

FD 9

VO 5

IS 0

SP 38

OP 48

$\mathrm{K} 1$ Indigenous knowledge

K1 Floods

K1 Resilience 
K1 Coping strategies

K1 Muzarabani

K1 Zimbabwe

SN 2212-4209

DO http://dx.doi.org/10.1016/j.ijdrr.2013.07.001

DS ScienceDirect

UL http://www.sciencedirect.com/science/article/pii/S2212420913000368

OL Unknown(0)

RT Journal Article

SR Print(0)

ID 153

A1 McGee,T. K.

T1 Public engagement in neighbourhood level wildfire mitigation and preparedness: Case studies from Canada, the US and Australia

JF Journal of environmental management

JO J.Environ.Manage.

YR 2011

VO 92

IS 10

SP 2524

$\mathrm{K} 1$ ecosystem resilience

$\mathrm{K} 1$ environmental legislation

$\mathrm{K} 1$ neighborhood

K1 participatory approach

$\mathrm{K} 1$ public sector

K1 urban planning

K1 wildfire

AB This study examined neighbourhood level wildfire mitigation programs being implemented in neighbourhoods in Canada (FireSmart-ForestWise), Australia (Community Fireguard) and the US (Firewise Communities). Semi-structured interviews were completed with 19 residents participating in the programs. A wide range of activities were completed as part of the three programs. Despite differences between the three programs, participants appeared to participate in the programs for three main reasons: Fire experience, agency involvement, and personal and family protection. A fire therefore provides a window of opportunity to engage residents in neighbourhood level wildfire mitigation programs. The neighbourhood level wildfire mitigation programs helped to reduce the wildfire risk, but also enhanced both community resilience and relationships between residents and government agencies. \&copy; 2011 Elsevier Ltd.

PP 24-28 Oval Road, London, NW1 7DX, United Kingdom

SN 03014797

LA English

LK file:///C:/Users/s9130263/Documents/Cases/McGee_2011.pdf

DB Compilation and indexing terms, Copyright 2013 Elsevier Inc.; GEOBASE

OL Unknown(0)

RT Journal Article

SR Print(0)

ID 1468

A1 McNamara,Karen

A1 Prasad,Shirleen

T1 Coping with extreme weather: communities in Fiji and Vanuatu share their experiences and knowledge

JF Climatic Change 
JO Clim.Change

YR 2014

FD 03/15

VO 123

IS 2

SP 121

OP 132

K1 CYCLONES

K1 DROUGHTS

K1 WATER storage

K1 FOOD -- Preservation

K1 EMERGENCY management

K1 RESEARCH

K1 TACTICS

AB Local communities across the Pacific Island region have long prepared for and managed extreme weather events. Strategies to cope with extreme weather, particularly cyclones and droughts, have involved using particular planting techniques, initiating innovative water storage practices, and employing food preservation tactics to survive. These local experiences and knowledge have been passed on between generations through stories and sharing practical know-how; however, very little formal documentation has transpired to date. This research attempts to document and synthesis these experiences and knowledge to safeguard them through written accounts but also demonstrate how Pacific communities can provide valuable, appropriate and effective strategies to prepare for and respond to extreme weather events. Indepth interviews $(n=40)$ were conducted with community members from three villages in Fiji (Naselesele, Qeleni and Yanuca) and three villages in Vanuatu (Piliura, Tassiriki and Lonamilo). While typically missing from community vulnerability and risk assessments in the Pacific, local experiences and knowledge are a core strength in enhancing adaptive capacity and planning community-based activities. ABSTRACT FROM AUTHOR]; Copyright of Climatic Change is the property of Springer Science \& Business Media B.V. and its content may not be copied or emailed to multiple sites or posted to a listserv without the copyright holder's express written permission. However, users may print, download, or email articles for individual use. This abstract may be abridged. No warranty is given about the accuracy of the copy. Users should refer to the original published version of the material for the full abstract. (Copyright applies to all Abstracts.)

NO M3: Article

SN 01650009

AN 94763107

LK http://library.smu.ca:2048/login?http://search.ebscohost.com/login.aspx?

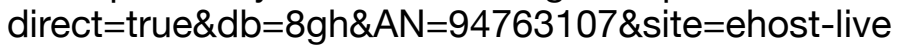

DO 10.1007/s10584-013-1047-2

DS EBSCO

OL Unknown(0)

RT Journal Article

SR Print(0)

ID 2332

A1 Mehta,Lyla

T1 Reflections on the Kutch Earthquake

JF Economic and Political Weekly

YR 2001

FD Aug. 4-10

VO 36

IS 31

SP 2931 
OP 2936

AB Despite the recent earthquake that wreaked havoc across Kutch, its people have long since learnt to cope with disasters and adapt their lives to the vagaries of nature. Yet while powerful social and political factors continue to manipulate calamities, it is equally important that administrators and NGOs understand Kutch's landscape history to make sense of the present earthquake and to ensure the rebuilding of Kutch is done sensitively and appropriately.

PB Economic and Political Weekly

SN 00129976

LA English

SF research-article; Copyright (c) 2001 Economic and Political Weekly

LK http://www.jstor.org/stable/4410942

DS JSTOR

OL Unknown(0)

RT Journal Article

SR Print(0)

ID 2639

A1 Mei,Estuning Tyas Wulan

A1 Lavigne,Franck

A1 Picquout,Adrien

A1 de Bélizal,Edouard

A1 Brunstein,Daniel

A1 Grancher,Delphine

A1 Sartohadi,Junun

A1 Cholik,Noer

A1 Vidal,Céline

T1 Lessons learned from the 2010 evacuations at Merapi volcano

JF Journal of Volcanology and Geothermal Research

JO J.Volcanol.Geotherm.Res.

YR 2013

FD $7 / 1$

VO 261

IS 0

SP 348

OP 365

K1 Evacuation

K1 Merapi

$\mathrm{K} 1$ Volcanic crisis

K1 2010 eruption

T2 Merapi eruption

SN $0377-0273$

DO http://dx.doi.org/10.1016/j.jvolgeores.2013.03.010

DS ScienceDirect

UL http://www.sciencedirect.com/science/article/pii/S0377027313000863

OL Unknown(0)

RT Journal Article

SR Print(0)

ID 2480

A1 Miceli,Renato

A1 Sotgiu,Igor

A1 Settanni,Michele

T1 Disaster preparedness and perception of flood risk: A study in an alpine valley in Italy JF Journal of Environmental Psychology 
JO J.Environ.Psychol.

YR 2008

FD 6

VO 28

IS 2

SP 164

OP 173

K1 Disaster preparedness

K1 Risk perception

K1 Emotions

K1 Flood risk

K1 Rasch model

SN 0272-4944

DO http://dx.doi.org/10.1016/j.jenvp.2007.10.006

DS ScienceDirect

UL http://www.sciencedirect.com/science/article/pii/S0272494407000904

OL Unknown(0)

RT Journal Article

SR Print(0)

ID 562

A1 Mimaki,Junko

A1 Takeuchi,Yukiko

A1 Shaw,Rajib

$\mathrm{T} 1$ The role of community-based organization in the promotion of disaster preparedness at the community level: A case study of a coastal town in the Kochi Prefecture of the Shikoku Region, Japan

JF Journal of Coastal Conservation

YR 2009

VO 13

IS 4

SP 207

$\mathrm{K} 1$ coastal zone

$\mathrm{K} 1$ community organization

$\mathrm{K} 1$ disaster management

$\mathrm{K} 1$ natural disaster

$\mathrm{K} 1$ rural area

K1 social capital

$\mathrm{K} 1$ tsunami

$\mathrm{K} 1$ typhoon

$\mathrm{K} 1$ voluntary approach

AB The Japanese rural coastal areas are inherently vulnerable to typhoons and tsunamis. Their vulnerability has been further increasing recently, in part due to social factors such as the aging of society and depopulation. Following the Kobe earthquake of 1995, the Japanese

government has promoted the Voluntary Disaster Preparedness Organization (VDPO) to build communities that are more sustainable and resilient to natural disasters. However, studies indicate that some VDPO activity has stagnated. The present study focuses on a rural coastal area in Japan and examines whether VDPO impacts residents' awareness of disaster preparedness and also examines ties among the community. The study relies on a questionnaire survey. It reveals that VDPO contributes to improving both awareness of disaster preparedness and ties in the community. \&copy; 2009 Springer Science+Business Media B.V. SN 14000350

LA English

LK http://dx.doi.org/10.1007/s11852-009-0065-8 
DB Compilation and indexing terms, Copyright 2013 Elsevier Inc.; GEOBASE

OL Unknown(0)

RT Journal Article

SR Print(0)

ID 1356

A1 Mitchell, Terry L.

A1 Griffin,Kara

A1 Stewart,Sherry $\mathrm{H}$.

A1 Loba,Pamela

T1 'We Will Never Ever Forget ...': The Swissair Flight 111 Disaster and its Impact on

Volunteers and Communities

JF Journal of Health Psychology

YR 2004

FD 03

VO 9

IS 2

SP 245

OP 262

K1 AIRCRAFT accidents

K1 COMMUNITIES

K1 HELP-seeking behavior

K1 VOLUNTEERS

K1 HEALTH

$\mathrm{K} 1$ DISASTERS

AB In collaboration with a Community Advisory Group we examined the impact of the 1998

Swissair Flight 111 disaster on volunteer responders and surrounding communities. We conducted qualitative interviews and administered a set of structured questionnaires to 13 volunteer disaster workers and conducted a focus group with community leaders. Community silence and limited help-seeking behaviour were typical reactions to the SA 111 disaster. The nature and duration of the disaster response efforts contributed to a probable 46 per cent PTSD rate in the community volunteers. Community-based, culturally appropriate followup, as well as the development of volunteer protocols for future disaster response efforts, are necessary to minimize long-term health impacts and to promote resilience among community residents and volunteers exposed to a major disaster. ABSTRACT FROM AUTHOR]; Copyright of Journal of Health Psychology is the property of Sage Publications, Ltd. and its content may not be copied or emailed to multiple sites or posted to a listserv without the copyright holder's express written permission. However, users may print, download, or email articles for individual use. This abstract may be abridged. No warranty is given about the accuracy of the copy. Users should refer to the original published version of the material for the full abstract.

(Copyright applies to all Abstracts.)

NO M3: Article

SN 13591053

AN 12453437

LK http://library.smu.ca:2048/login?http://search.ebscohost.com/login.aspx?

direct=true\&db=aph\&AN=12453437\&site=ehost-live

DO 10.1177/1359105304040890

DS EBSCO

OL Unknown(0)

RT Journal Article

SR Print(0)

ID 693

A1 Morello-Frosch,Rachel 
A1 Brown,Phil

A1 Lyson, Mercedes

A1 Cohen,Alison

A1 Krupa,Kimberly

T1 Community voice, vision, and resilience in post-Hurricane Katrina recovery

JF Environmental Justice

YR 2011

VO 4

IS 1

SP 71

K1 contaminated land

$\mathrm{K} 1$ disaster management

$\mathrm{K} 1$ disaster relief

$\mathrm{K} 1$ environmental justice

K1 extreme event

$\mathrm{K} 1$ grassroots level

K1 Hurricane Katrina 2005

K1 infrastructural development

$\mathrm{K} 1$ public health

$\mathrm{K} 1$ questionnaire survey

K1 safety

$\mathrm{K} 1$ sludge

$\mathrm{K} 1$ state role

K1 toxicity

AB Hurricane Katrina has mobilized community-based environmental justice organizing and advocacy and injected a strong social justice analysis of extreme weather events and disaster recovery. Using interviews and observations with New Orleans activists and organizations, we examine three community and advocacy-based rebuilding and organizing projects that arose as a result of diminished local and federal government infrastructure and regulatory engagement: 1) a labor-environment coalition which rebuilt a single neighborhood block as a demonstration project that also provided safety and health training; 2) activists' analyses of sludge toxicity in diverse neighborhood and point source locations; and 3) community organizing to address the re-opening of public schools on contaminated land. This leads us to a broader examination of neighborhood activism regarding rebuilding, barriers and opportunities posed by political and state entities, and the connection between environmental hazards and public health infrastructure problems. An in-depth look at these three case studies underscores the importance of community-based environmental justice organizations for building grassroots infrastructure for effective disaster planning and to ensure that a foundation exists to advance recovery efforts, particularly in situations when government infrastructure and support is lacking. \&copy; 2011, Mary Ann Liebert, Inc.

PP 140 Huguenot Street, New Rochelle, NY 10801-5215, United States

SN 19394071

LA English

LK file:///C:/Users/s9130263/Documents/Cases/Morello-Frosch_etal_2011.pdf

DB Compilation and indexing terms, Copyright 2013 Elsevier Inc.; GEOBASE

OL Unknown(0)

RT Journal Article

SR Print(0)

ID 596

A1 Murali,Janakaraj

A1 Afifi,Tamer

T1 Rainfall variability, food security and human mobility in the Janjgir-Champa district of

Chhattisgarh state, India 
JF Climate and Development

YR 2014

VO 6

IS 1

SP 28

K1 agricultural worker

K1 climate change

K1 drought

K1 employment

K1 farmers attitude

$\mathrm{K} 1$ flood frequency

$\mathrm{K} 1$ food production

K1 food security

$\mathrm{K} 1$ internal migration

$\mathrm{K} 1$ labor migration

K1 mobility

$\mathrm{K} 1$ monoculture

$\mathrm{K} 1$ monsoon

$\mathrm{K} 1$ rainfall

$\mathrm{K} 1$ rice

K1 rural economy

$\mathrm{K} 1$ seasonal variation

$\mathrm{K} 1$ village

$\mathrm{K} 1$ water stress

AB The impacts of rainfall variability are threatening food production systems, leading to losses of livelihood and food insecurity. The frequency and intensity of floods and drought are likely to be higher as a result of climate change. This case study presents an empirical account of the impacts of rainfall variability on agriculture, food security, livelihoods and human mobility in the Janjigir-Champa district of Chhattisgarh. The research tests the hypothesis that human migration is a major coping mechanism against climate variability. The findings confirm that a coordination mechanism exists between rainfall changes (i.e. erratic rainfall patterns in terms of delayed monsoons, seasonal shifts, drought and floods) and livelihood and food security of a number of farmers and farm labourers in the research site. Because there is only a single annual harvest of paddy rice (practiced as monoculture) in the research site, which is partly due to the non-availability of water for a second crop, marginal farmers and farm labourers are left with very few options in finding sufficient employment in and around their villages. Some people cope with the situation by seeking assistance from their relatives, friends and the government. However, seasonal and permanent migrations are the most opted-for coping strategies in the study area. \&copy; 2013 \&copy; 2013 The Author(s). Published by Taylor \& Francis.

PP 14a St. Cross Street, Clerkenwell, London, EC1N 8XA, United Kingdom

SN 17565529

LA English

LK http://dx.doi.org/10.1080/17565529.2013.867248

DB Compilation and indexing terms, Copyright 2013 Elsevier Inc.; GEOBASE

OL Unknown(0)

RT Journal Article

SR Print(0)

ID 2137

A1 Myers,Candice A.

A1 Slack,Tim

A1 Singelmann, Joachim 
T1 Social Vulnerability and Migration in the Wake of Disaster: The Case of Hurricanes Katrina and Rita

JF Population and Environment

JO Popul.Environ.

YR 2008

FD Jul.

VO 29

IS 6

SP 271

OP 291

AB This study explores the relationship between place-based social vulnerability and postdisaster migration in the U.S. Gulf Coast region following Hurricanes Katrina and Rita. Using county-level data from the U.S. Census Bureau, we develop a regional index of social vulnerability and examine how its various dimensions are related to migration patterns in the wake of the storms. Our results show that places characterized by greater proportions of disadvantaged populations, housing damage, and, to a lesser degree, more densely built environments were significantly more likely to experience outmigration following the hurricanes. Our results also show that these relationships were not spatially random, but rather exhibited significant geographic clustering. We conclude with a discussion of the implications of these findings for future research and public policy.

PB Springer

SN 01990039

LA English

SF research-article; Copyright (C) 2008 Springer

LK http://www.jstor.org/stable/40212360

DS JSTOR

OL Unknown(0)

RT Journal Article

SR Print(0)

ID 646

A1 Nakanishi,Hitomi

A1 Matsuo,Kojiro

A1 Black,John

T1 Transportation planning methodologies for post-disaster recovery in regional communities: The East Japan Earthquake and tsunami 2011

JF Journal of Transport Geography

JO J.Transp.Geogr.

YR 2013

VO 31

SP 181

$\mathrm{K} 1$ disaster management

K1 metropolitan area

K1 modeling

K1 sustainability

K1 Tohoku earthquake 2011

$\mathrm{K} 1$ transportation planning

K1 tsunami

K1 urban transport

AB Spatial planning provides tools to government authorities that support integrated response strategies as part of the disaster management but regional communities outside of the metropolitan areas often lack the necessary capacity and resources to implement these approaches. Unlike in the USA, there are no guidelines for transportation planners in coping with post-disaster situations in Japan. There is a substantive literature on institutions, concepts 
of urban sustainability and resilience, community engagement and travel behavioral adjustments to natural disasters and man-made disruptions to transportation supply in the emergency phase but only limited research into travel demand modeling in the recovery phase. This paper focuses on the recovery phase - and constructs conceptual and operational demand and supply models for the recovery phase to help seek options for more sustainable outcome. The methodology is applied to the city of Ishinomaki, Japan, one of the many regional communities devastated by the March, 2011 earthquake and tsunami where only limited capacity and data are available. Future hypothetical scenarios for the city are analyzed to illustrate the potential practicality of the proposed methodology with the indicators of travel performance of the scenarios in the case study area. The paper concludes with implication to planning, including the full re-location of peninsular villages, and further research needs. \&copy; 2013 Elsevier Ltd.

PP Langford Lane, Kidlington, Oxford, OX5 1GB, United Kingdom

SN 09666923

LA English

LK http://dx.doi.org/10.1016/j.jtrangeo.2013.07.005

DB Compilation and indexing terms, Copyright 2013 Elsevier Inc.; GEOBASE

OL Unknown(0)

RT Journal Article

SR Print(0)

ID 196

A1 Newman,Soren

A1 Carroll,Matthew

A1 Jakes,Pamela

A1 Higgins, Lorie

T1 Hurricanes and wildfires: Generic characteristics of community adaptive capacity

JF Environmental Hazards

YR 2014

VO 13

IS 1

SP 21

K1 disturbance

$\mathrm{K} 1$ hazard management

$\mathrm{K} 1$ hurricane

$\mathrm{K} 1$ risk assessment

$\mathrm{K} 1$ traditional knowledge

$\mathrm{K} 1$ wildfire

AB This paper explores the question: to what extent is human community adaptive capacity generic versus hazard-specific? To what extent does having adaptive capacity for one type of disturbance indicate that communities also have adaptive capacity for other types of disturbance that they currently or may someday face? We did in-depth case studies in two Lee County, Florida communities to explore the extent to which residents have adaptive capacity for both hurricanes and wildfires. Although wildfire risk has significantly less salience than hurricane risk for participants, our results suggest that case study communities have built generic elements of adaptive capacity that are generalizable to address both disturbances: (1) interactional and organizational capacities; (2) professional knowledge and extra-local networks; and (3) local knowledge, resources, and skills. We conclude by offering examples of what an all-hazard community might look like based on the development of generic adaptive capacity. \&copy; 2013 Taylor \& Francis.

PP 4 Park Square, Milton Park, Abingdon, Oxfordshire, OX14 4RN, United Kingdom

SN 17477891

LA English

LK http://dx.doi.org/10.1080/17477891.2013.841090 
DB Compilation and indexing terms, Copyright 2013 Elsevier Inc.; GEOBASE

OL Unknown(0)

RT Journal Article

SR Print(0)

ID 744

A1 Newton,J.

T1 An assessment of coping with environmental hazards in northern Aboriginal communities JF Canadian Geographer / Geographie Canadien

YR 1995

VO 39

IS 2

SP 112

K1 environment

AB Impressions of the north, its landscape, and people are drawn largely from public images, not personal experience, making misconceptions commonplace among non-residents. The objective of this research is to improve our understanding of how communities cope with flood hazards through an assessment of the complex integration of traditional knowledge, community evolution, and modern technologies. This intersection of forces could influence vulnerability to natural hazards and affect preparedness and response. Field investigations were conducted in Aklavik, N.W.T., Attawapiskat, Ontario, and Fort Liard, N.W.T. as case studies. Central to the research design are distinctions between perceptions, attitudes, and activities at three operational levels: individual; communal; governmental - and an appreciation of how these levels interrelate in response to flood hazards. The research findings confirm the crucial value of local environmental knowledge, identify the influence of changing social structures on community vulnerability, and underline the jurisdictionally.

LA English

DB Compilation and indexing terms, Copyright 2013 Elsevier Inc.; GEOBASE

OL Unknown(0)

RT Journal Article

SR Print(0)

ID 2666

A1 $\mathrm{Ng}, \mathrm{K}$.

A1 Phillips,M. R.

A1 Borges, $P$.

A1 Thomas, $T$.

A1 August,P.

A1 Calado, $\mathrm{H}$.

A1 Veloso-Gomes,F.

T1 Maintaining a way of life for São Miguel Island (the Azores archipelago, Portugal): An

assessment of coastal processes and protection

JF Science of The Total Environment

JO Sci.Total Environ.

YR 2014

FD 5/15

VO 481

IS 0

SP 142

OP 156

K1 Coastal vulnerability

K1 Coastal hazard

K1 Sustainable development

K1 Multifunctional artificial reef 
$\mathrm{K} 1 \mathrm{Sea}$ level rise

K1 North Atlantic Ocean

SN 0048-9697

DO http://dx.doi.org/10.1016/j.scitotenv.2014.01.067

DS ScienceDirect

UL http://www.sciencedirect.com/science/article/pii/S004896971400076X

OL Unknown(0)

RT Journal Article

SR Print(0)

ID 503

A1 Nguyen, Kien V.

A1 James, Helen

T1 Measuring household resilience to floods: A case study in the Vietnamese Mekong River

Delta

JF Ecology and Society

YR 2013

VO 18

IS 3

K1 adaptive management

K1 coping strategy

$\mathrm{K} 1$ disaster management

$\mathrm{K} 1$ factor analysis

K1 flood

K1 socioeconomic impact

K1 vulnerability

AB The flood is a well-known phenomenon in the Vietnamese Mekong River Delta (MRD).

Although people have experienced the impact of floods for years, some adapt well, but others are vulnerable to floods. Resilience to floods is a useful concept to study the capacity of rural households to cope with, adapt to, and benefit from floods. Knowledge of the resilience of households to floods can help disaster risk managers to design policies for living with floods. Most researchers attempt to define the concept of resilience; very little research operationalizes it in the real context of "living with floods". We employ a subjective well-being approach to measure households' resilience to floods. Items that related to households' capacity to cope with, adapt to, and benefit from floods were developed using both a five-point Likert scale and dichotomous responses. A factor analysis using a standardized form of data was employed to identify underlying factors that explain different properties of households' resilience to floods. Three properties of households' resilience to floods were found: (1) households'confidence in securing food, income, health, and evacuation during floods and recovery after floods; (2) households' confidence in securing their homes not being affected by a large flood event such as the 2000 flood; (3) households' interests in learning and practicing new flood-based farming practices that are fully adapted to floods for improving household income during the flood season. The findings assist in designing adaptive measures to cope with future flooding in the MRD. \&copy; 2013 by the author(s).

PP 1125 Colonel By Drive, Ottawa, ON K1S 5B6, Canada

SN 17083087

LA English

LK http://dx.doi.org/10.5751/ES-05427-180313

DB Compilation and indexing terms, Copyright 2013 Elsevier Inc.; GEOBASE

OL Unknown(0)

RT Journal Article

SR Print(0)

ID 2495 
A1 Okada,Tetsuya

A1 Haynes, Katharine

A1 Bird,Deanne

A1 van den Honert,Robin

A1 King,David

T1 Recovery and resettlement following the 2011 flash flooding in the Lockyer Valley

JF International Journal of Disaster Risk Reduction

YR 2014

FD 6

VO 8

IS 0

SP 20

OP 31

K1 Recovery

K1 Resettlement

K1 Flood

K1 Lockyer Valley

K1 Queensland

K1 Community

SN 2212-4209

DO http://dx.doi.org/10.1016/j.ijdrr.2014.01.001

DS ScienceDirect

UL http://www.sciencedirect.com/science/article/pii/S2212420914000028

OL Unknown(0)

RT Journal Article

SR Print(0)

ID 2557

A1 Oloruntoba,Richard

T1 Plans never go according to plan: An empirical analysis of challenges to plans during the 2009 Victoria bushfires

JF Technological Forecasting and Social Change

YR 2013

FD 11

VO 80

IS 9

SP 1674

OP 1702

K1 Disaster logistics

K1 Black Saturday

K1 Emergency and disaster planning

K1 Disaster operations management

K1 Victorian bushfires

K1 Wildfires

T2 Planning and Foresight Methodologies in Emergency Preparedness and Management

SN 0040-1625

DO http://dx.doi.org/10.1016/j.techfore.2012.12.002

DS ScienceDirect

UL http://www.sciencedirect.com/science/article/pii/S0040162512003174

OL Unknown(0)

RT Journal Article

SR Print(0)

ID 226 
A1 Omidvar,Babak

A1 Zafari,Hossein

A1 Khakpour,Mehdi

T1 Evaluation of public participation in reconstruction of Bam, Iran, after the 2003 earthquake

JF Natural Hazards

JO Nat.Hazards

YR 2011

VO 59

IS 3

SP 1397

K1 Bam earthquake 2003

$\mathrm{K} 1$ decision making

$\mathrm{K} 1$ disaster management

K1 housing policy

$\mathrm{K} 1$ local participation

K1 reconstruction

K1 urban housing

K1 urban planning

$A B$ In the midst of the ever-increasing natural and human-induced disasters, where many of the preparedness and mitigation measures show inefficiencies, there is narrow margin for decisionmakers to make mistakes by misallocating budgets, designing infeasible reconstruction plans, and in other terms, making decisions not in line with the public preferences. In particular, public participation in post-disaster measures seems undoubtedly necessary to reduce the possible economic, social, political, and cultural conflicts around the stressful community after a major disaster. This paper aims at evaluating the role of public participation in increasing the reconstruction phase efficiency through a case study of the reconstruction process in Bam, a southeastern Iranian city, after the 2003 earthquake. It is attempted to identify the major motivators of the public participation through a combination of quantitative and qualitative studies. Statistical data are generated through a set of questionnaires being filled by a number of 200 randomly selected survivors. The numerical results were then discussed through the Focus Group technique sessions to determine the main contributors to the public participation. It is later found that the answers are found among the performance of the reconstruction authorities, financial policies, emotional resiliency of the survivors, public information mechanisms, public satisfaction, the pace of reconstruction, and temporary housing policies. \&copy; 2011 Springer Science+Business Media B.V.

PP Van Godewijckstraat 30, Dordrecht, 3311 GZ, Netherlands

SN 0921030X

LA English

LK http://dx.doi.org/10.1007/s11069-011-9842-4

DB Compilation and indexing terms, Copyright 2013 Elsevier Inc.; GEOBASE

OL Unknown(0)

RT Journal Article

SR Print(0)

ID 78

A1 Osbahr,Henny

A1 Twyman, Chasca

A1 Neil Adger,W.

A1 Thomas,David S. G.

T1 Effective livelihood adaptation to climate change disturbance: Scale dimensions of practice in Mozambique

JF Geoforum

JO Geoforum

YR 2008 
VO 39

IS 6

SP 1951

K1 adaptation

K1 climate change

$\mathrm{K} 1$ developing world

K1 global climate

$\mathrm{K} 1$ poverty alleviation

K1 rural economy

AB Natural resource-dependent societies in developing countries are facing increased pressures linked to global climate change. While social-ecological systems evolve to accommodate variability, there is growing evidence that changes in drought, storm and flood extremes are increasing exposure of currently vulnerable populations. In many countries in Africa, these pressures are compounded by disruption to institutions and variability in livelihoods and income. The interactions of both rapid and slow onset livelihood disturbance contribute to enduring poverty and slow processes of rural livelihood renewal across a complex landscape. We explore cross-scale dynamics in coping and adaptation response, drawing on qualitative data from a case study in Mozambique. The research characterises the engagements across multiple institutional scales and the types of agents involved, providing insight into emergent conditions for adaptation to climate change in rural economies. The analysis explores local responses to climate shocks, food security and poverty reduction, through informal institutions, forms of livelihood diversification and collective land-use systems that allow reciprocity, flexibility and the ability to buffer shocks. However, the analysis shows that agricultural initiatives have helped to facilitate effective livelihood renewal, through the reorganisation of social institutions and opportunities for communication, innovation and micro-credit. Although there are challenges to mainstreaming adaptation at different scales, this research shows why it is critical to assess how policies can protect conditions for emergence of livelihood transformation. \&copy; 2008 Elsevier Ltd. All rights reserved.

SN 00167185

LA English

LK C:IUsers\s9130263\Documents\Cases\Osbahr_etal_2008.pdf

DB Compilation and indexing terms, Copyright 2013 Elsevier Inc.; GEOBASE

OL Unknown(0)

RT Generic

SR Print(0)

ID 298

A1 Parrinello, Giacomo

T1 The city-territory: large-scale planning and development policies in the aftermath of the

Belice valley earthquake (Sicily, 1968)

JF Planning Perspectives

JO Plann.Perspect.

YR 2013

FD 10

VO 28

IS 4

SP 571

OP 593

K1 EARTHQUAKES -- Italy -- History

K1 NATURAL disasters

K1 EMERGENCY management

$\mathrm{K} 1 \mathrm{CITIES} \&$ towns -- Italy

K1 URBAN planning -- Italy -- Case studies

K1 SICILY (Italy) -- Politics \& government -- 1945- 
K1 BELICE River Valley (Italy)

K1 Belice Valley

K1 city-territory

K1 development policies

K1 earthquake

K1 large-scale planning

$\mathrm{AB}$ This article examines a particular case of post-disaster planning: the 'city-territory' of the

Belice Valley. As a consequence of an earthquake which devastated a depressed rural area of western Sicily in 1968, town planners, supported by special post-disaster legislation, undertook a planning experiment aimed at redeveloping the disaster area and promoting its social and economic transformation. The Belice Valley plan became an experiment in socioeconomic engineering, and the idea of combining reconstruction and development was associated with a particular spatial layout: the 'city-territory'. Based on archival research, this work examines this planning idea, its roots and its outcome. I will argue that, despite its peculiarities, the 'city-territory' idea was deeply rooted in the Italian and international culture and practices of the day, which were particularly favourable for large-scale planning and development policies. I will also demonstrate that the attempt to realize this plan for a 'cityterritory' was hindered by a radically transformed context and by a general crisis of industrial development policies. This case study, therefore, attempts to shed light on a key issue of 1960 s and 1970s international planning culture and practice, and illustrates some of the reasons for its partial failure. ABSTRACT FROM PUBLISHER]; Copyright of Planning Perspectives is the property of Routledge and its content may not be copied or emailed to multiple sites or posted to a listserv without the copyright holder's express written permission. However, users may print, download, or email articles for individual use. This abstract may be abridged. No warranty is given about the accuracy of the copy. Users should refer to the original published version of the material for the full abstract. (Copyright applies to all Abstracts.)

NO TY: CASE; M3: Case Study

SN 02665433

AN 92982219

LK http://library.smu.ca:2048/login?http://search.ebscohost.com/login.aspx?

direct=true \&db=hia\&AN=92982219\&site=ehost-live

DO 10.1080/02665433.2013.774538

DS EBSCO

OL Unknown(0)

RT Journal Article

SR Print(0)

ID 513

A1 Parvin, Gulsan Ara

A1 Shaw,Rajib

T1 Microfinance institutions and a coastal community's disaster risk reduction, response, and recovery process: A case study of Hatiya, Bangladesh

JF Disasters

JO Disasters

YR 2013

VO 37

IS 1

SP 165

$\mathrm{K} 1$ coastal zone

$\mathrm{K} 1$ disaster management

$\mathrm{K} 1$ empirical analysis

$\mathrm{K} 1$ microfinance

$\mathrm{K} 1$ risk assessment 
$\mathrm{K} 1$ risk perception

$A B$ Several researchers have examined the role of microfinance institutions (MFIs) in poverty alleviation, but the part that they play in disaster risk reduction remains unaddressed. Through an empirical study of Hatiya Island, one of the most vulnerable coastal communities of Bangladesh, this research evaluates perceptions of MFI support for the disaster risk reduction, response, and recovery process. The findings reveal no change in relation to risk reduction and income and occupation aspects for more than one-half of the clients of MFIs. In addition, only 26 per cent of them have witnessed less damage as a result of being members of MFIs. One can argue, though, that the longer the membership time period the better the disaster preparedness, response, and recovery process. The outcomes of this study could help to guide the current efforts of MFIs to enhance the ability of coastal communities to prepare for and to recover from disasters efficiently and effectively. \&copy; 2013 The Author(s). Journal compilation \&copy; Overseas Development Institute, 2013.

PP 9600 Garsington Road, Oxford, OX4 2XG, United Kingdom

SN 03613666

LA English

LK file:///C:/Users/s9130263/Documents/Cases/Parvin_\&_Shaw_2012.pdf

DB Compilation and indexing terms, Copyright 2013 Elsevier Inc.; GEOBASE

OL Unknown(0)

RT Journal Article

SR Print(0)

ID 1791

A1 Parvin,Gulsan Ara

A1 Takahashi,Fumito

A1 Shaw,Rajib

T1 Coastal hazards and community-coping methods in Bangladesh

JF Journal of Coastal Conservation

YR 2008

FD Nov 2008

VO 12

IS 4

SP 181

OP 193

K1 Environmental Studies

K1 CSA / ASCE Civil Engineering Abstracts

K1 ASFA 2: Ocean Technology Policy \& Non-Living Resources

K1 Oceanic Abstracts

K1 ASFA 3: Aquatic Pollution \& Environmental Quality

K1 Sustainability Science Abstracts

K1 Marine

K1 ISW, Bangladesh

K1 employment

K1 nongovernmental organizations

K1 Socioeconomics

K1 Water supplies

K1 Coastal zone management

K1 Water supply

K1 Hazards

K1 Coastal zone

K1 Socioeconomic aspects

K1 Perception

K1 Conservation

K1 Shelters 
K1 vulnerability

$\mathrm{K} 1$ coastal hazards

K1 Q5 01523:Conservation, wildlife management and recreation

K1 O 4090:Conservation and Environmental Protection

K1 Q2 02124:Coastal zone management

K1 M3 1010:Issues in Sustainable Development

$\mathrm{AB}$ Addressing one of the most vulnerable coastal communities in Bangladesh, this paper

explores people's perception and vulnerabilities to coastal hazards. At the same time, it

investigates the methods that communities apply to cope with different coastal hazards.

Findings revealed that people perceived an increase in both the intensity of hazards and their

vulnerabilities. In spite of having a number of socio-economic and locational factors enhancing

their vulnerabilities, the community is creating their own ways to cope with these hazards. For

different aspects of life like shelter, employment, water supply, and health, communities apply

different coping methods that vary with the types of hazard. Efforts have also been made by

governments and NGOs to manage coastal hazards. By highlighting both community-coping

methods and efforts of development organizations, this paper attempts to devise an integrated approach for managing the coastal hazards that occur in Bangladesh.

NO Source type: scholarlyjournals; Object type: Article; Object type: Feature; CSAUnique: OBMD-0011184339; AccNum: 11889191; InputCenter: CS1011252; DOI: 10.1007/

s11852-009-0044-0; ISSN: 1400-0350; ElecISSN: 1874-7841; Peer Reviewed: true

PB Springer Science+Business Media

PP Netherlands

SN $1400-0350$

AD International Environment and Disaster Management, Graduate School of Global

Environmental Studies, University of Kyoto, Kyoto, Japan

AN 297295093; 11889191

LA English

LK http://search.proquest.com/docview/297295093?accountid=13908

DO http://dx.doi.org/10.1007/s11852-009-0044-0

DB GeoRef

DS ProQuest

UL http://QN8PM6GK2Q.search.serialssolutions.com/directLink?

\&atitle=Coastal+hazards+and+community-

coping+methods+in+Bangladesh\&author=Parvin\%252C+Gulsan+Ara\%253BTakahashi\%252C

+Fumito\%253BShaw\%252C+Rajib\&issn=14000350\&title=Journal+of+Coastal+Conservation\&v olume $=12 \&$ issue $=4 \&$ date $=2008-11-01 \&$ spage $=181 \& \mathrm{id}=$ doi:

10.1007\%252Fs11852-009-0044-0\&sid=ProQ_ss\&genre=article; http://dx.doi.org/10.1007/

s11852-009-0044-0

OL Unknown(0)

RT Journal Article

SR Print(0)

ID 2746

A1 Pasupuleti,Ram Sateesh

T1 Designing culturally responsive built environments in post disaster contexts: Tsunami

affected fishing settlements in Tamilnadu, India

JF International Journal of Disaster Risk Reduction

YR 2013

FD 12

VO 6

IS 0

SP 28

OP 39

K1 Culture 
K1 Architecture

K1 Tsunami

K1 Tamilnadu.

SN 2212-4209

DO http://dx.doi.org/10.1016/j.ijdrr.2013.03.008

DS ScienceDirect

UL http://www.sciencedirect.com/science/article/pii/S221242091300023X

OL Unknown(0)

RT Journal Article

SR Print(0)

ID 2486

A1 Penning-Rowsell,Edmund C.

A1 Sultana,Parvin

A1 Thompson,Paul M.

T1 The 'last resort'? Population movement in response to climate-related hazards in

Bangladesh

JF Environmental Science \& Policy

JO Environ.Sci.\& Policy

YR 2013

FD 3

VO 27, Supplement 1

IS 0

SP S44

OP S59

K1 Hazards

K1 Bangladesh

K1 Impacts

K1 Evacuation

K1 Migration

K1 Focus groups

T2 Global environmental change, extreme environmental events and 'environmental migration': exploring the connections

SN 1462-9011

DO http://dx.doi.org/10.1016/j.envsci.2012.03.009

DS ScienceDirect

UL http://www.sciencedirect.com/science/article/pii/S1462901112000470

OL Unknown(0)

RT Journal Article

SR Print(0)

ID 190

A1 Perez-Lugo,M.

T1 The mass media and disaster awareness in Puerto Rico: A case study of the floods in Barrio Tortugo

JF Organization and Environment

YR 2001

VO 14

IS 1

SP 55

$\mathrm{K} 1$ disaster management

K1 flood

K1 media role

$\mathrm{K} 1$ natural disaster 
K1 perception

$A B$ Most of the literature about disasters assumes that the media are the most important mitigation tool for manager officials because its content creates disaster and risk awareness. This assumption proposes only three actors in the process of effective disaster management: the government officials that generate disaster information, the media that transmit it, and the public, who receives the information and acts accordingly. A case study of a flood in a rural community in Puerto Rico suggests that this model is inefficient in explaining how disaster awareness is created and how this relates to effective disaster mitigation. The data suggest that the literature fails to recognize important factors that increase or even create vulnerability to hazards. It also neglects other important actors, such as community leaders, and the actions of other groups and institutions that have indirect impact in generating the disaster situation.

SN 10860266

LA English

DB Compilation and indexing terms, Copyright 2013 Elsevier Inc.; GEOBASE

OL Unknown(0)

RT Journal Article

SR Print(0)

ID 1015

A1 Porio,Emma

T1 Vulnerability, Adaptation, and Resilience to Floods and Climate Change-Related Risks among Marginal, Riverine Communities in Metro Manila

JF Asian Journal of Social Science

YR 2011

FD 09

VO 39

IS 4

SP 425

OP 445

K1 URBAN poor

K1 RESILIENCE (Personality trait)

K1 POOR families

K1 FLOODS -- Social aspects

K1 CLIMATIC changes -- Risk management

K1 ADAPTABILITY (Psychology)

K1 MANILA (Philippines)

K1 PHILIPPINES

$\mathrm{K} 1$ climate change adaptation and resilience

K1 ecological-environmental vulnerability

$\mathrm{K} 1$ riverine communities

$\mathrm{K} 1$ social vulnerability

K1 urban development

AB Abstract This study examines the vulnerability, adaptation, and resilience of urban poor households living in the riverine communities of the three flood prone areas in Metro Manila, namely, (1) Pasig-Marikina River basin, (2) West Mangahan, and (3) the KAMANAVA area

(Kalookan, Malabon, Navotas, Valenzuela). Based on a survey of 300 urban poor households in 14 communities located in these flood basins, the study found that the environmentalecological vulnerability of the low-lying flood prone areas interacts strongly with the social vulnerability of urban poor households, highlighting the effects of climate related changes (sea level rise, increased typhoons, intensity of monsoon rains, floods and tidal/storm surges) on this vulnerable population. Most of the households have low-incomes, live in slum/squatter settlements and do not have adequate access to potable water, electricity, health, sewage and sanitation facilities. About two-thirds of them suffered losses (e.g., income, work, health/ sickness, household appliances/things, housing damage) from typhoons, floods, and tidal/ 
storm surges but only a small portion of them obtained help from formal institutions (e.g., local government units or LGUs, charitable agencies) and informal support networks (relatives/ neighbors/friends). Of these, a third of these households appeared more vulnerable and consistently incurred higher losses (e.g., income and workdays) and intense inconveniences (e.g., water source buried by floods, toilets blocked and overflowed with wastes/large worms to their floors) compared to their neighbors. Both urban poor households and their local governments have formulated adaptation strategies in response to the increasing effects of climate change. Few of the local governments built river barriers, improved their drainage systems, installed water diversion techniques (e.g., 'bombastic') and disaster warning systems and increased the capacity of their officials to assist during evacuations. Meanwhile, some urban poor households have adapted to a 'water-based lifestyle' (e.g., raising the floors/ increasing the number of floors of their homes, building makeshift bridges among households in swampy areas, building Styrofoam boats for transport, etc.). But on the whole, both the urban poor residents and the formal institutions (LGUs, national agencies) need resources and capability building to increase their capacity to adapt to the effects of climate change.

ABSTRACT FROM AUTHOR]; Copyright of Asian Journal of Social Science is the property of Brill Academic Publishers and its content may not be copied or emailed to multiple sites or posted to a listserv without the copyright holder's express written permission. However, users may print, download, or email articles for individual use. This abstract may be abridged. No warranty is given about the accuracy of the copy. Users should refer to the original published version of the material for the full abstract. (Copyright applies to all Abstracts.)

NO M3: Article

SN 15684849

AN 67348152

LK http://library.smu.ca:2048/login?http://search.ebscohost.com/login.aspx?

direct $=$ true $\& \mathrm{db}=a p h \& A N=67348152 \&$ site $=$ ehost-live

DO 10.1163/156853111X597260

DS EBSCO

OL Unknown(0)

RT Journal Article

SR Print(0)

ID 1698

A1 Porteous, James

T1 The tsunami gardeners

JF Ecos

YR 2008

FD 02

IS 141

SP 12

OP 14

K1 ORGANIC gardening

K1 RESTORATION ecology

K1 TSUNAMI damage

K1 SELF-reliant living

K1 CIVIL war

K1 REHABILITATION

K1 COST \& standard of living

K1 GALLE (Sri Lanka)

K1 MATARA (Sri Lanka)

K1 SRI Lanka

AB The article states on the development of self sufficiency in Sri Lankan communities striving to overcome tsunami damage and effects from the ongoing civil war by employing organic gardening and ecosystem restoration program. It mentions about the international consortium 
of European aid organisations, Solidar providing committed, longer term assistance through both post-tsunami recovery and conflict resolution programs in Sri Lanka, and about Solidar's Coastal Community Rehabilitation Project (CCRP) which contributed by reducing household expenses, food provision and income generation capacity in Galle and Matara, both in Sri Lanka.

NO M3: Article

SN 03114546

AN 31429536

LK file://C:/Users/s9130263/Documents/Cases/Porteous_2008.pdf

DS EBSCO

OL Unknown(0)

RT Journal Article

SR Print(0)

ID 524

A1 Prabhakar,S. V. R. K.

A1 Iwata,Yuuki

A1 Shaw,Rajib

A1 Soulakova,Julia

A1 Takeuchi,Yukiko

A1 Kunita,Takuji

T1 Climate change implications for disaster risk management in Japan: A case study on perceptions of risk management personnel and communities in Saijo city

JF Environmental Hazards

YR 2012

VO 11

IS 1

SP 16

K1 climate change

$\mathrm{K} 1$ disaster management

K1 extreme event

$\mathrm{K} 1$ local government

K1 participatory approach

$\mathrm{K} 1$ precipitation intensity

$\mathrm{K} 1$ risk assessment

$\mathrm{K} 1$ risk perception

$\mathrm{K} 1$ typhoon

K1 uncertainty analysis

K1 vulnerability

$A B$ This paper reviews climate change impacts and the existing disaster risk management system in Japan and offers the results of a structured questionnaire survey of the community leaders and disaster risk management personnel of Saijo city of Japan that assesses their perceptions about dealing with the extreme disasters by the existing disaster risk management systems. This study was inspired by the record number of typhoon landfall that has surprised the local government and communities in 2004. While unearthing the hidden vulnerabilities in cities like Saijo, this event has loosened the confidence of local communities on the disaster risk management systems. From the study, we conclude that the existing disaster risk management systems need further fillip and that the proactive community involvement in disaster risk management is still in nascent stages. Associating with the scientific community, involving the local communities (including the elderly), enhancing the redundancy in disaster risk management systems, inculcating strategic thinking and micro-level planning, conducting vulnerability assessments by considering the special circumstances including resource constraints of small cities and better policy coordination across the administrative hierarchy are 
some important considerations for dealing with the uncertainty brought by the extreme events. \&copy; 2012 Taylor \& Francis.

PP 4 Park Square, Milton Park, Abingdon, Oxfordshire, OX14 4RN, United Kingdom

SN 17477891

LA English

LK http://dx.doi.org/10.1080/17477891.2011.618821

DB Compilation and indexing terms, Copyright 2013 Elsevier Inc.; GEOBASE

OL Unknown(0)

RT Journal Article

SR Print(0)

ID 2500

A1 Prior,Tim

A1 Eriksen, Christine

T1 Wildfire preparedness, community cohesion and social-ecological systems

JF Global Environmental Change

JO Global Environ.Change

YR 2013

FD 12

VO 23

IS 6

SP 1575

OP 1586

K1 Wildfire

K1 Preparedness

K1 Community cohesion

K1 Resilience

K1 Social-ecological system

SN 0959-3780

DO http://dx.doi.org/10.1016/j.gloenvcha.2013.09.016

DS ScienceDirect

UL http://www.sciencedirect.com/science/article/pii/S0959378013001684

OL Unknown(0)

RT Journal Article

SR Print(0)

ID 181

A1 Prno,Jason

A1 Bradshaw,Ben

A1 Wandel,Johanna

A1 Pearce, Tristan

A1 Smit,Barry

A1 Tozer,Laura

T1 Community vulnerability to climate change in the context of other exposure-sensitivities in Kugluktuk, Nunavut

JF Polar Research

JO Polar Res.

YR 2011

VO 30

IS SUPPL.1

$\mathrm{K} 1$ assessment method

K1 climate change

$\mathrm{K} 1$ environmental change

$\mathrm{K} 1$ nature-society relations 
K1 perforation

K1 vulnerability

$\mathrm{AB}$ Climate change in the Canadian north is, and will be, managed by communities that are already experiencing social, political, economic and other environmental changes. Hence, there is a need to understand vulnerability to climate change in the context of multiple exposuresensitivities at the community level. This article responds to this perceived knowledge need based on a case study of the community of Kugluktuk in Nunavut, Canada. An established approach for vulnerability assessment is used to identify current climatic and non-climatic exposure-sensitivities along with their associated contemporary adaptation strategies. This assessment of current vulnerability is used as a basis to consider Kugluktuk's possible vulnerability to climatic change in the future. Current climate-related exposure-sensitivities in Kugluktuk relate primarily to subsistence harvesting and community infrastructure. Thinner and less stable ice conditions and unpredictable weather patterns are making travel and harvesting more dangerous and some community infrastructure is sensitive to permafrost melt and extreme weather events (e.g., flash floods). The ability of individuals and households to adapt to these and other climatic exposure-sensitivities is influenced by non-climatic factors that condition adaptive capacity including substance abuse, the erosion of traditional knowledge and youth suicide. These and other non-climatic factors often underpin adaptive capacity to deal with and adapt to changing conditions and must be considered in an assessment of vulnerability. This research argues that Northern communities are challenged by multiple exposuresensitivities- beyond just those posed by climate-and effective adaptation to climate change requires consideration if not resolution of socio-economic and other issues in communities. \&copy; $2011 \mathrm{~J}$. Prno et al.

PP Framsenteret Hjalmar Johansensgate 14, Tromsoe, 9296, Norway

SN 08000395

LA English

LK http://dx.doi.org/10.3402/polar.v30i0.7363

DB Compilation and indexing terms, Copyright 2013 Elsevier Inc.; GEOBASE

OL Unknown(0)

RT Journal Article

SR Print(0)

ID 496

A1 Quarantelli,E.

T1 Sheltering and housing after major community disasters: case studies and general observations.

YR 1982

K1 American

K1 disasters

K1 Grand Island tornado

$\mathrm{K} 1$ housing

K1 Wilkes Barre flood

K1 Xenia tornado

$\mathrm{AB}$ An examination of the sheltering and housing aspects of disasters, by the Disaster Research Center (DRC) which reviewed the literature and previously unanalyzed data on that subject. The literature is scanty and unsystematic, and marked by conceptual confusion between sheltering and housing. Part of the confusion may be eliminated by distinguishing among emergency sheltering, temporary sheltering, temporary housing, and permanent housing. Three studies focus on sheltering and housing in three major American disasters; the Wilkes-Barre flood, the Xenia tornado, and the Grand Island tornado. From the case studies, a series of observations and conclusions are drawn.-from US Govt Reports Announcements, 17, 1982

LA English

DB Compilation and indexing terms, Copyright 2013 Elsevier Inc.; GEOBASE 
OL Unknown(0)

RT Journal Article

SR Print(0)

ID 422

A1 Rainham,Daniel

T1 Risk Communication and Public Response to Industrial Chemical Contamination in Sydney, Nova Scotia: A Case Study

JF Journal of environmental health

JO J.Environ. Health

YR 2002

FD 12

VO 65

IS 5

SP 26

K1 INDUSTRIAL wastes

K1 ESTUARIES

K1 POLYCYCLIC aromatic hydrocarbons

K1 NOVA Scotia

K1 CANADA

AB The town of Sydney, located on the north coast of Nova Scotia, is Canada's most contaminated community. The local tidal estuary, called the tar ponds, was used as a receptacle for industrial waste from a century of coke production and steel making and is estimated to contain more than 700,000 metric tons of polycyclic aromatic hydrocarbons, 50,000 metric tons of polychlorinated biphenyls, and many other residuals including arsenic, naphthalene, and toluene. Many residents have expressed consternation over the potential for exposure and subsequent health effects from the ponds. Recent epidemiological studies estimate a 30 to 40 percent increased incidence in several types of cancer within the community. This paper examines the claims and responses made by a variety of interested parties about the chemical contamination in Sydney. It also considers how those claims, in addition to a number of other mediating factors, may have influenced the local community in the mobilization of a response to the contamination. ABSTRACT FROM AUTHOR]; Copyright of Journal of Environmental Health is the property of National Environmental Health Association and its content may not be copied or emailed to multiple sites or posted to a listserv without the copyright holder's express written permission. However, users may print, download, or email articles for individual use. This abstract may be abridged. No warranty is given about the accuracy of the copy. Users should refer to the original published version of the material for the full abstract. (Copyright applies to all Abstracts.)

NO M3: Article

SN 00220892

AN 8572667

LK http://library.smu.ca:2048/login?http://search.ebscohost.com/login.aspx? direct=true\&db=8gh\&AN=8572667\&site=ehost-live

DS EBSCO

OL Unknown(0)

RT Journal Article

SR Print(0)

ID 389

A1 Ray-Bennett,Nibedita

T1 The role of microcredit in reducing women's vulnerabilities to multiple disasters JF Disasters

JO Disasters

YR 2010 
FD 01

VO 34

IS 1

SP 240

OP 260

K1 DISASTERS

K1 WOMEN

K1 MICROFINANCE

K1 HOUSEHOLDS

K1 GENDER inequality

K1 NONGOVERNMENTAL organizations

K1 microcredit

$\mathrm{K} 1$ multiple disasters

K1 Orissa

K1 vulnerability

K1 women-headed households

$A B$ This article explores the relationship between microcredit and vulnerability reduction for women-headed households in'multiple disasters'. Here multiple disasters are understood as disasters that occur in one specific place and cause severe devastation. The case study covers the super-cyclone in 1999, floods in 2001 and 2003, and drought in 2002 in Orissa, India. The study entailed eight months fieldwork and interviews with several governmental and nongovernmental officials and 12 women-headed households from different social castes. The findings suggest that microcredit is a useful tool to replace women's livelihood assets that have been lost in multiple disasters. But inefficient microcredit delivery can cause microdebts and exacerbate caste, class and gender inequalities. It is posited that microcredit delivery cannot achieve vulnerability reduction for women in multiple disasters unless it is complemented by effective financial services, integrated policy planning and disaster management between government, non-governmental organisations and the community. ABSTRACT FROM AUTHOR]; Copyright of Disasters is the property of Wiley-Blackwell and its content may not be copied or emailed to multiple sites or posted to a listserv without the copyright holder's express written permission. However, users may print, download, or email articles for individual use. This abstract may be abridged. No warranty is given about the accuracy of the copy. Users should refer to the original published version of the material for the full abstract.

(Copyright applies to all Abstracts.)

NO M3: Article

PB Wiley-Blackwell

SN 03613666

AN 45470397

LK C:IUsers\s9130263\Documents\Cases\Ray-Bennett_2010.pdf

DO 10.1111/j.1467-7717.2009.01127.x

DS EBSCO

OL Unknown(0)

RT Journal Article

SR Print(0)

ID 136

A1 Ray-Bennett,Nibedita S.

T1 The influence of caste, class and gender in surviving multiple disasters: A case study from Orissa, India

JF Environmental Hazards

YR 2009

VO 8

IS 1

SP 5 
$\mathrm{K} 1$ caste system

$\mathrm{K} 1$ cyclone

$\mathrm{K} 1$ disaster management

$\mathrm{K} 1$ documentary source

$\mathrm{K} 1$ drought

$\mathrm{K} 1$ female headed household

$\mathrm{K} 1$ household survey

$\mathrm{K} 1$ questionnaire survey

$\mathrm{K} 1$ research work

$\mathrm{K} 1$ survival

K1 vulnerability

$\mathrm{K} 1$ womens status

AB Sociological and anthropological studies in India reveal that caste, class and gender in everyday life are both rigid and dynamic, but little is known about how they influence the survival mechanisms of women during 'multiple disasters', nor about how women negotiate with these structural mores to meet their cultural and biological needs. This is explored through the experiences of 12 women-headed households from different social castes in Orissa, India. Multiple disasters or disasters that occur in 'one specific place' (such as floods, cyclone and drought) are regular events in coastal parts of the state of Orissa. The super-cyclone of 1999, two floods of 2001 and 2003 and drought of 2000 and 2002 form the case study. Participant observation, in-depth interviews and documentary evidence complement the fieldwork. The findings suggest a complex interplay of caste, class and gender in surviving the multiple disasters including structural mutability under the purview of social organization. In doing so, wo en demonstrated their individual and collective agencies in order to meet their cultural and biological needs under severe crisis. This research stresses that gender and disaster studies must include a consideration of caste and class for effective disaster management and social vulnerability reduction. \&copy; 2009 Earthscan ISSN: 1747-7891 (print).

PP 14a St. Cross Street, Clerkenwell, London, EC1N 8XA, United Kingdom

SN 17477891

LA English

LK C: \Users\s9130263\Documents\Cases

DB Compilation and indexing terms, Copyright 2013 Elsevier Inc.; GEOBASE

OL Unknown(0)

RT Journal Article

SR Print(0)

ID 2247

A1 Reenberg,Anette

A1 Birch-Thomsen, Torben

A1 Mertz,Ole

A1 Fog,Bjarne

A1 Christiansen,Sofus

T1 Adaptation of Human Coping Strategies in a Small Island Society in the SW Pacific - 50 Years of Change in the Coupled Human-Environment System on Bellona, Solomon Islands JF Human Ecology

JO Hum.Ecol.

YR 2008

FD Dec.

VO 36

IS 6

SP 807

OP 819

$\mathrm{AB}$ Coupled human-environmental timelines are used to explore the temporal coevolution of driving forces and adaptive strategies from the 1960s to 2006 on Bellona in the SW Pacific. 
Climatic events and agro-environmental conditions are assessed in conjunction with issues such as population dynamics, agricultural strategies, non-agricultural activities, transport and infrastructure, migration, education, political conditions, etc. Satellite imagery and aerial photos reveal relative stability in agricultural land use intensity despite an increase in de facto population (51\% from 1966-2006). Results of questionnaire survey of 48 households show that the utilization of natural resources (notably shifting cultivation and fisheries) remains widespread, although it is increasingly supplemented by other income generating activities (e. g., shopkeeping, private business, government employment). Group interviews are used to discuss ways in which the local communities' adaptive resource management strategies have been employed in the face of climatic and socioeconomic events and changes in the recent past. Fifty years' development is described as a combination of continuity and change. Resource management practices are only marginally impacted by different stress factors, but the importance of agriculture has been decreasing in relative terms. Culturally determined bonds have become a main ' mechanism' to cope with environmental or socioeconomic stress and the Bellonese have become less vulnerable to external shocks.

PB Springer

SN 03007839

LA English

SF research-article; Copyright (C) 2008 Springer

LK http://www.jstor.org/stable/40343957

DS JSTOR

OL Unknown(0)

RT Journal Article

SR Print(0)

ID 1689

A1 Ritchie,Liesel Ashley

A1 Gill,Duane A.

A1 Farnham,Courtney N.

T1 Recreancy Revisited: Beliefs about Institutional Failure Following the Exxon Valdez Oil Spill JF Society \& Natural Resources

YR 2013

FD 06

VO 26

IS 6

SP 655

OP 671

K1 EXXON Valdez Oil Spill, Alaska, 1989

K1 ENVIRONMENTAL disasters

K1 BELIEF \& doubt

K1 ACQUISITION of data

K1 SOCIAL capital (Sociology)

K1 CORDOVA (Ala.)

$\mathrm{K} 1$ disaster litigation

K1 Exxon Valdez oil spill

K1 institutional failure

K1 oil spills

K1 recreancy

K1 technological disasters

AB In 1993, Freudenburg suggested the term "recreancy" to refer to behaviors associated with institutional failures, which he distinguished from the consequences of such failures. This article revisits issues related to recreancy associated with the 1989Exxon Valdezoil spill. Using qualitative data collected in Cordova, Alaska, between 2002 and 2010, we examine notions about recreancy and technological disasters. Findings highlight perceptions of institutional 
failures associated with the spill and cleanup activities, providing insights into the social consequences of such failures for those most directly affected by them, including loss of ontological security, the emergence of corrosive communities, and diminished social capital. We extend the discussion about recreancy to include organizational processes intended to address economic, social, and environmental consequences of technological disasters. Our data reveal a persistence of beliefs about recreancy associated with theExxon Valdezoil spill and the subsequent litigation, and their consequences for long-term community impacts.

ABSTRACT FROM AUTHOR]; Copyright of Society \& Natural Resources is the property of Routledge and its content may not be copied or emailed to multiple sites or posted to a listserv without the copyright holder's express written permission. However, users may print, download, or email articles for individual use. This abstract may be abridged. No warranty is given about the accuracy of the copy. Users should refer to the original published version of the material for the full abstract. (Copyright applies to all Abstracts.)

NO M3: Article

SN 08941920

AN 87666115

LK http://library.smu.ca:2048/login?http://search.ebscohost.com/login.aspx?

direct=true $\& \mathrm{db}=8 \mathrm{gh} \& \mathrm{AN}=87666115 \&$ site=ehost-live

DO 10.1080/08941920.2012.690066

DS EBSCO

OL Unknown(0)

RT Journal Article

SR Print(0)

ID 995

A1 Rivera,Jason D.

A1 Nickels,Ashley E.

T1 Social Capital, Community Resilience, and Faith-based Organizations in Disaster Recovery JF Conference Papers -- American Political Science Association

YR 2010

FD 01

SP 1

OP 47

K1 COMMUNITY organization

K1 SOCIAL capital (Sociology)

K1 HURRICANE Katrina, 2005

K1 COMMUNITY development

K1 COMMUNITY life

K1 NEWTON, K

$A B$ The article examines how the Mary Queen of Vietnam (MQVN) Catholic Church, a community-based organization intervene to address the needs of its community in the wake of the Hurricane Katrina in New Orleans, Louisiana. How MQVN garnered social capital within its surrounding community to pursue successful community development without governmental support is examined. K. Newton's proposition on civic distrust and confidence is also discussed.

NO M3: Article

AN 94851533

LK http://library.smu.ca:2048/login?http://search.ebscohost.com/login.aspx?

direct $=$ true $\& \mathrm{db}=a p h \& A N=94851533 \&$ site=ehost-live

DS EBSCO

OL Unknown(0)

RT Journal Article

SR Print(0) 
ID 820

A1 Rivera-Trejo,Fabian

A1 Soto-Corts, Gabriel

A1 Mndez-Antonio,Baldemar

T1 The 2007 flood in Tabasco, Mexico: an integral analysis of a devastating phenomenon

JF International Journal of River Basin Management

YR 2010

FD 12/01

VO 8

IS 3

SP 255

OP 267

NO Social Sciences (General), Business, Trade, Accountancy

PB T\&F Informa UK Ltd

SN 1571-5124; 1814-2060

LK https://www.swetswise.com/swoc-web/link/access_db?

issn $=1814-2060 \& \mathrm{vol}=00008 \&$ iss $=00003 \&$ page $=255 \&$ year $=2010$

OL Unknown(0)

RT Journal Article

SR Print(0)

ID 1703

A1 Rosenbaum,I.

T1 Two Oil Spills--Interrelation between the Socioeconomic Structure and Impact on Seafood Marketing Systems

JF International Journal of Environmental Studies

JO Int.J.Environ.Stud.

YR 1979

FD 07

VO 14

IS 1

SP 55

K1 OIL spills

K1 ECONOMIC aspects

K1 SEAFOOD industry

$A B$ Little research has been done, to date, on the socioeconomic effects of oil spills. The socioeconomic investigations which were carried out in connection with the "Saint Peter" oil spill off the Colombian/Ecuadorian coast, and the "Urquiola" oil spill at La Coruña harbor in north-western Spain have provided an opportunity to document different effects on the seafood marketing systems in the two communities. The differences of the impact of the oil spills permitted an insight into the interrelation between socioeconomic factors both with respect to the effects produced and the degree of success of the corrective measures where such were implemented. ABSTRACT FROM AUTHOR]; Copyright of International Journal of Environmental Studies is the property of Routledge and its content may not be copied or emailed to multiple sites or posted to a listserv without the copyright holder's express written permission. However, users may print, download, or email articles for individual use. This abstract may be abridged. No warranty is given about the accuracy of the copy. Users should refer to the original published version of the material for the full abstract. (Copyright applies to all Abstracts.)

NO M3: Article

SN 00207233

AN 5828244

LK http://library.smu.ca:2048/login?http://search.ebscohost.com/login.aspx?

direct $=$ true $\& \mathrm{db}=8 \mathrm{gh} \& A \mathrm{~N}=5828244 \&$ site $=$ =host-live 
DS EBSCO

OL Unknown(0)

RT Journal Article

SR Print(0)

ID 592

A1 Rumbach,Andrew

A1 Foley,Dolores

T1 Indigenous institutions and their role in disaster risk reduction and resilience: Evidence from the 2009 Tsunami in American Samoa

JF Ecology and Society

YR 2014

VO 19

IS 1

$\mathrm{K} 1$ decision making

$\mathrm{K} 1$ disaster management

$\mathrm{K} 1$ hazard assessment

$\mathrm{K} 1$ indigenous knowledge

$\mathrm{K} 1$ risk assessment

$\mathrm{K} 1$ tsunami

$\mathrm{K} 1$ village

$\mathrm{AB}$ Indigineity has emerged as an important area of focus for research and policy making on disaster risk reduction (DRR) and resilience. Most research on indigeneity and DRR centers on indigenous knowledge and its integration with western scientific understandings of hazards and risk. Through a detailed case study of the 2009 tsunami in American Samoa, we argue that indigenous institutions also play a critical role in disaster risk reduction and resilience. Based on original data from semistructured interviews, village planning meetings, and focus group discussions, we describe how the indigenous institutions of fa'a Samoa, or the culture of Samoa, operated in a time of crisis by: (1) structuring emergency decision making and authority; (2) assigning roles and responsibilities during crises; (3) building effective lines of communication between villages and outside actors; (4) providing a system of accountability for vulnerable people; and (5) acting as gatekeepers to villages and mobilizing social groups to act. We then suggest some ways that indigenous institutions could be better leveraged to help create more resilient communities. \&copy; 2014 by the author(s).

SN 17083087

LA English

LK http://dx.doi.org/10.5751/ES-06189-190119

DB Compilation and indexing terms, Copyright 2013 Elsevier Inc.; GEOBASE

OL Unknown(0)

RT Journal Article

SR Print(0)

ID 3082

A1 Safford,Thomas G.

A1 Ulrich, Jessica D.

A1 Hamilton, Lawrence C.

T1 Public perceptions of the response to the Deepwater Horizon oil spill: Personal experiences, information sources, and social context

JF Journal of environmental management

JO J.Environ.Manage.

YR 2012

FD 12/30

VO 113

IS 0 
SP 31

OP 39

K1 Environmental disasters

K1 Organizations

K1 Oil spill response

K1 Public perceptions

K1 Sociology

SN 0301-4797

DO http://dx.doi.org/10.1016/j.jenvman.2012.08.022

DS ScienceDirect

UL http://www.sciencedirect.com/science/article/pii/S0301479712004306

OL Unknown(0)

RT Journal Article

SR Print(0)

ID 412

A1 Sakdapolrak,Patrick

A1 Promburom,Panomsak

A1 Reif,Alexander

T1 Why successful in situ adaptation with environmental stress does not prevent people from migrating? Empirical evidence from Northern Thailand

JF Climate \& Development

YR 2014

FD 01

VO 6

IS 1

SP 38

OP 45

K1 RURAL geography

K1 RAINFALL probabilities

K1 FOOD security

K1 INDUSTRIAL organization (Economic theory)

K1 THAILAND

$\mathrm{K} 1$ environmental risk

$\mathrm{K} 1$ migration

$\mathrm{K} 1$ rural livelihoods

$\mathrm{K} 1$ social resilience

$A B$ This article examines the relationship between rainfall-related events and trends, livelihood and food security and migration in rural upland communities in Thailand. This study was conducted as one of eight case studies within the framework of the 'Where the Rain Falls' Project. This article is based on empirical research in four villages in the Province Lamphun, Northern Thailand. The households' livelihood in the research area is characterized by a high level of on and off-farm diversification and integration into national and global market structures. Migration - internal as well as international - is widespread. Based on the data gathered in a multi-method field-based research design, the study observed that while households are exposed to various rainfall related stressors, such as the extreme rainfall in 2011 which resulted in heavy floods in the Central Plains of Thailand, migration is not considered as a primary coping and risk mitigation strategy. Environmental factors are furthermore not the primary explanatory factor for pattern of mobility. The study highlights the complex relationship between environmental factors including rainfall and migration beyond determinism notions of environmental migration. This study points out that while migration might not be caused by rainfall-related events and trends, through migration induced translocal connectedness, the social resilience of exposed households and communities can be strengthened. ABSTRACT FROM AUTHOR]; Copyright of Climate \& Development is the 
property of Earthscan and its content may not be copied or emailed to multiple sites or posted to a listserv without the copyright holder's express written permission. However, users may print, download, or email articles for individual use. This abstract may be abridged. No warranty is given about the accuracy of the copy. Users should refer to the original published version of the material for the full abstract. (Copyright applies to all Abstracts.)

NO M3: Article

SN 17565529

AN 94885978

LK http://library.smu.ca:2048/login?http://search.ebscohost.com/login.aspx?

direct $=$ true $\& \mathrm{db}=8 \mathrm{gh} \& \mathrm{AN}=94885978 \&$ site $=$ ehost-live

DO 10.1080/17565529.2013.826129

DS EBSCO

OL Unknown(0)

RT Journal Article

SR Print(0)

ID 2441

A1 Saldaña-Zorrilla,Sergio O.

T1 Stakeholders' views in reducing rural vulnerability to natural disasters in Southern Mexico: Hazard exposure and coping and adaptive capacity

JF Global Environmental Change

JO Global Environ.Change

YR 2008

FD 10

VO 18

IS 4

SP 583

OP 597

K1 Vulnerability

K1 Rural poverty

K1 Subsistence farmers

K1 Development

K1 Natural disasters

K1 Trade

K1 Adaptation

$\mathrm{K} 1$ Productive re-orientation

T2 Local evidence on vulnerabilities and adaptations to global environmental change

SN 0959-3780

DO http://dx.doi.org/10.1016/j.gloenvcha.2008.09.004

DS ScienceDirect

UL http://www.sciencedirect.com/science/article/pii/S095937800800085X

OL Unknown(0)

RT Journal Article

SR Print(0)

ID 2599

A1 Samaddar,Subhajyoti

A1 Chatterjee,Roshni

A1 Misra,Bijayanad

A1 Tatano,Hirokazu

T1 Outcome-expectancy and self-efficacy: Reasons or results of flood preparedness intention? JF International Journal of Disaster Risk Reduction

YR 2014

FD 6 
VO 8

IS 0

SP 91

OP 99

$\mathrm{K} 1$ Casual chain model vs. Associationist view

K1 Household flood preparedness

K1 Self-efficacy

K1 Mumbai

SN 2212-4209

DO http://dx.doi.org/10.1016/j.ijdrr.2014.02.002

DS ScienceDirect

UL http://www.sciencedirect.com/science/article/pii/S221242091400017X

OL Unknown(0)

RT Journal Article

SR Print(0)

ID 1684

A1 Sanderson,David

A1 Sharma,Anshu

A1 Anderson, Juliet

T1 NGO permanent housing 10 years after the Gujarat earthquake: revisiting the FICCI-CARE Gujarat rehabilitation programme

JF Environment \& Urbanization

YR 2012

FD 04

VO 24

IS 1

SP 233

OP 247

$\mathrm{K} 1$ Earthquake

$\mathrm{K} 1$ housing

K1 India

K1 NGO

K1 people

$\mathrm{K} 1$ reconstruction

AB The January 2001 earthquake that struck the state of Gujarat in India damaged or destroyed some 8,000 villages and 490 towns. In the months and years after the earthquake, many organizations undertook widespread reconstruction programmes. One such collaboration between the NGO CARE India and the Federation of Indian Chambers of Commerce and Industry (FICCI) built 5,554 permanent houses as well as schools and community centres in 23 villages. This paper revisits 10 of the 23 villages that were partially or fully rebuilt by FICClCARE, 10 years after the earthquake. It finds that while the houses remain structurally strong and are mostly in use, residents' levels of satisfaction, perception and usage are mixed. A central theme concerns the initial prioritization of seismic safety, which has sacrificed longerterm considerations of comfort, adaptability and the environment. The paper describes the houses that were built and presents findings according to structural condition, engagement in design, adaptations, house selling and perceptions of safety. The discussion presents four issues that emerge from the findings and wider research. The paper ends by proposing a simple equation for good housing, which places people's involvement in building processes as the vital component. ABSTRACT FROM PUBLISHER]; Copyright of Environment \& Urbanization is the property of Sage Publications, Ltd. and its content may not be copied or emailed to multiple sites or posted to a listserv without the copyright holder's express written permission. However, users may print, download, or email articles for individual use. This abstract may be abridged. No warranty is given about the accuracy of the copy. Users should 
refer to the original published version of the material for the full abstract. (Copyright applies to all Abstracts.)

NO M3: Article

SN 09562478

AN 74674445

LK http://library.smu.ca:2048/login?http://search.ebscohost.com/login.aspx?

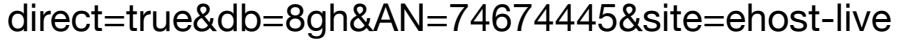

DO 10.1177/0956247811431218

DS EBSCO

OL Unknown(0)

RT Journal Article

SR Print(0)

ID 2121

A1 Sawada,Yasuyuki

A1 Shimizutani,Satoshi

T1 How Do People Cope with Natural Disasters? Evidence from the Great Hanshin-Awaji

(Kobe) Earthquake in 1995

JF Journal of Money, Credit and Banking

JO J.Money Credit Bank.

YR 2008

FD Mar. - Apr.

VO 40

IS $2 / 3$

SP 463

OP 488

AB This paper investigates the coping strategies employed by victims of the Great HanshinAwaji (Kobe) earthquake in 1995. Using a unique household data set, we show that households that held a large amount of collateralizable assets before the catastrophe and were free from a binding borrowing constraint were able to maintain their consumption levels by borrowing. In contrast, households subject to a binding borrowing constraint before the disaster were unable to borrow to cope with the losses inflicted by the earthquake. On the other hand, both types of households relied on private transfers, depending on the extent of the damage.

PB Wiley

SN 00222879

LA English

SF research-article; Copyright (C) 2008 Ohio State University Press

LK http://www.jstor.org/stable/25096261

DS JSTOR

OL Unknown(0)

RT Journal Article

SR Print(0)

ID 1997

A1 Scheper-Hughes,Nancy

T1 Katrina: The Disaster and Its Doubles

JF Anthropology Today

YR 2005

FD Dec.

VO 21

IS 6

SP 2

OP 4

PB Royal Anthropological Institute of Great Britain and Ireland 
SN 0268540X

LA English

SF research-article; Copyright (C) 2005 Royal Anthropological Institute of Great Britain and Ireland

LK http://www.jstor.org/stable/3694939

DS JSTOR

OL Unknown(0)

RT Journal Article

SR Print(0)

ID 829

A1 Scolobig,Anna

A1 Broto,Vanesa Castan

A1 Zabala,Aiora

T1 Integrating multiple perspectives in social multicriteria evaluation of flood-mitigation alternatives: the case of Malborghetto-Valbruna

JF Environment and Planning - Part C

YR 2008

FD 01/01

VO 26

IS 6

SP 1143

OP 1161

NO Geography (General), Environmental Sciences

PB Pion Limited

SN 0263-774X; 1472-3425

LK file://C:/Users/s9130263/Documents/Cases/Scolobig_etal_2008.pdf;

OL Unknown(0)

RT Journal Article

SR Print(0)

ID 1993

A1 Shaffer,Gary P.

A1 Day,John W.

A1 Mack,Sarah

A1 Kemp,G. Paul

A1 Heerden, Ivor van

A1 Poirrier,Michael A.

A1 Westphal,Karen A.

A1 FitzGerald,Duncan

A1 Milanes,Andrew

A1 Morris, Chad A.

A1 Bea,Robert

A1 Penland,P. Shea

T1 The MRGO Navigation Project: A Massive Human-Induced Environmental, Economic, and Storm Disaster

JF Journal of Coastal Research

JO J.Coast.Res.

YR 2009

FD FALL

IS , SPECIAL ISSUE NO. 54. Geologic and Environmental Dynamics of the Pontchartrain Basin

SP 206

OP 224 
$A B$ It is generally felt in the water resources community that the most significant twenty-first century public works projects will be those undertaken to correct environmental damage caused by twentieth century projects. A second axiom is that the switch from economic development to restoration and mitigation, what we call redemption, often will be precipitated by disaster. Finally, it must be expected that the repair project will cost far more than the initial public investment but also may have economic revitalization potential far exceeding anticipated environmental benefits. We examine this cycle for the federally funded Mississippi River Gulf Outlet (MRGO) navigation project east of New Orleans, beginning with its much heralded birth in 1963 as a $122 \mathrm{~km}$ long free-flowing tidal canal connecting New Orleans to the Gulf of Mexico and ending with its recent de-authorization and closure. We track the direct and indirect effects of the project through its commercial failure, and then on to the official denial, the pervasive environmental impacts, and finally exposure of its role in flooding New Orleans during Hurricane Betsy in 1965 and more seriously during Hurricane Katrina in 2005. Post deauthorization planning to curtail continuing environmental and economic damage now offers an opportunity to apply lessons that have been learned and to reinstate natural processes that were disrupted or interrupted by the MRGO during the half-century of its operation. One surprising outcome is that the restoration program may turn out to be more commercially successful than the original navigation project, which was conceived as an agent of economic transformation. The U.S. Army Core of Engineers still does not acknowledge, even in the face of compelling scientific evidence, that the MRGO project was a significant cause of early and catastrophic flooding of the Upper and Lower 9th Wards, St. Bernard Parish, and New Orleans East during Hurricane Katrina. A modeling effort that removed the MRGO from the landscape, and restored the cypress swamps and marshes killed by the MRGO, reduced flooding from Hurricane Katrina by $80 \%$. We conclude that the MRGO spelled the difference between localized flooding, and the catastrophe that killed 1464 people and inflicted tens of billions of dollars of property damages. If the MRGO-caused economic damages associated with Hurricanes Betsy and Katrina are combined with those of construction, operation and maintenance, and wetlands destroyed, then the total economic cost of the MRGO is in the hundreds of billions of dollars.

PB Coastal Education \& Research Foundation, Inc.

SN 07490208

LA English

SF research-article; Copyright (C) 2009 Coastal Education \& Research Foundation, Inc. LK http://www.jstor.org/stable/25737481

DS JSTOR

OL Unknown(0)

RT Journal Article

SR Print(0)

ID 1990

A1 Shannon Lee Dawdy

T1 The Taphonomy of Disaster and the (Re)Formation of New Orleans

JF American Anthropologist

YR 2006

FD Dec.

VO 108

IS 4

SP 719

OP 730

$A B$ Using observations from recent participation in post-Katrina recovery efforts in New Orleans, I make the case in this article that taphonomic processes such as trash removal, deposition, earthmoving, and demolition are a primary medium through which individuals and communities reconstitute themselves following a disaster. Taphonomy, or the formation of the archaeological record, does not simply reflect social processes, it is a social process. The 
taphonomic processes currently underway through the clean-up and rebuilding efforts in New Orleans dramatically illustrate this point. I recommend that both ethnographers and archaeologists undertake a fine-grained ethnoarchaeology of disaster. I engage with the literature of disaster to illustrate the potentials I see for this type of study, particularly as it pertains to the culture-nature nexus, perceptions of vulnerability, and the revelatory power of disasters.

NO SE: New Series

PB Wiley on behalf of the American Anthropological Association

SN 00027294

LA English

SF research-article; Copyright (C) 2006 American Anthropological Association

LK http://www.jstor.org/stable/4496514

DS JSTOR

OL Unknown(0)

RT Journal Article

SR Print(0)

ID 121

A1 Shearer,Christine

T1 The political ecology of climate adaptation assistance: Alaska Natives, displacement, and relocation

JF Journal of Political Ecology

YR 2012

VO 19

IS 1

SP 174

$\mathrm{K} 1$ adaptive management

$\mathrm{K} 1$ climate change

$\mathrm{K} 1$ climate effect

$\mathrm{K} 1$ disaster management

$\mathrm{K} 1$ indigenous population

$\mathrm{K} 1$ migration

$\mathrm{K} 1$ relocation

$\mathrm{K} 1$ risk assessment

$\mathrm{K} 1$ state role

$A B$ Although much research on climate change has focused on its disproportionate effects on the Global South, communities-particularly indigenous populations-within "developed" nations in the Global North can also face significant effects and inadequate assistance. One example is the native village and city of Kivalina in northwest Alaska. Through a case study of Kivalina, this article explores the gaps in U.S. policy for relocating Alaska Natives due to the effects of climate change. There is currently no policy in place-within the United States or internationallyfor the resettlement of communities displaced by climate change. And in the United States there is no lead agency in charge of relocating displaced communities, despite several U.S. government reports stating that at least four Alaska Native villages, including Kivalina, must be resettled due to warming Arctic temperatures and erosion. This leaves government agencies in charge of assisting villages like Kivalina, such as the Federal Emergency Management Agency and the Army Corps of Engineers, who are responsible for helping ensure Kivalina's safety but are not empowered to innovate new procedures and holistically address what is an unprecedented problem: climate change. This has left Kivalina in what is termed here an administrative orbit, with residents made to work their way through a patchwork of various government programs and procedures that are time-consuming and often insufficient. In exploring these intra-national inequities, this article examines how a protocol specifically designed for those displaced by climate change, such as "climigration," could be merged with 
existing government efforts around emergency management to help prevent disasters before they occur, and to protect at-risk communities like Kivalina.

PP Anthropology Bldg, Rm 316,, PO Box 210030 Tucson, AZ 85721, United States

SN 10730451

LA English

DB Compilation and indexing terms, Copyright 2013 Elsevier Inc.; GEOBASE

OL Unknown(0)

RT Journal Article

SR Print(0)

ID 2118

A1 Simpson,Edward

A1 Alwis,Malathi de

T1 Remembering Natural Disaster: Politics and Culture of Memorials in Gujarat and Sri Lanka JF Anthropology Today

YR 2008

FD Aug.

VO 24

IS 4

SP 6

OP 12

PB Royal Anthropological Institute of Great Britain and Ireland

SN 0268540X

LA English

SF research-article; Copyright (C) 2008 Royal Anthropological Institute of Great Britain and Ireland

LK http://www.jstor.org/stable/20179934

DS JSTOR

OL Unknown(0)

RT Journal Article

SR Print(0)

ID 1671

A1 So-Min Cheong

T1 Community Adaptation to the Hebei-Spirit Oil Spill

JF Ecology \& Society

YR 2012

FD 09

VO 17

IS 3

SP 452

OP 458

K1 OIL spills

K1 ADAPTATION (Biology)

K1 ENVIRONMENTAL disasters

K1 ENVIRONMENTAL management

$\mathrm{K} 1$ OIL pollution of rivers, harbors, etc

K1 community adaptation

K1 community dependence

K1 Hebei-Spirit

K1 knowledge

K1 oil spill

$\mathrm{K} 1$ resource 
$A B$ The focus of the research is the significance of dependence for communities to survive and adapt in times of environmental disasters. It shifts the emphasis on self-reliant communities for survival and examines the types and effects of dependence and external linkages by analyzing the range of community responses that include initial responses, early social impact, compensation, and conflicts after the Hebei-Spirit oil spill in December 2007 in Korea. The findings reveal that dependence is necessary, and the effects of dependence can be both positive and negative depending on the relations between external entities and affected communities as well as the community capacity to absorb resources and information.

ABSTRACT FROM AUTHOR]; Copyright of Ecology \& Society is the property of Resilience Alliance and its content may not be copied or emailed to multiple sites or posted to a listserv without the copyright holder's express written permission. However, users may print, download, or email articles for individual use. This abstract may be abridged. No warranty is given about the accuracy of the copy. Users should refer to the original published version of the material for the full abstract. (Copyright applies to all Abstracts.)

NO M3: Article

SN 17083087

AN 82347734

LK http://library.smu.ca:2048/login?http://search.ebscohost.com/login.aspx?

direct=true \&db=8gh\&AN=82347734\&site=ehost-live

DS EBSCO

OL Unknown(0)

RT Journal Article

SR Print(0)

ID 2042

A1 Spence,Patric R.

A1 Lachlan,Kenneth A.

A1 Griffin,Donyale R.

T1 Crisis Communication, Race, and Natural Disasters

JF Journal of Black Studies

JO J.Black Stud.

YR 2007

FD Mar.

VO 37

IS 4, Katrina: Race, Class, and Poverty

SP 539

OP 554

AB This study compares differences in crisis preparation, informationseeking patterns, and media use on the basis of race in the aftermath of Hurricane Katrina. Surveys are collected from 935 Katrina evacuees relocated in different areas of the United States. Results indicate differences in crisis preparation and information seeking on the basis of race. Results also demonstrate a continued need to create messages encouraging crisis preparation, especially among at-risk subpopulations.

PB Sage Publications, Inc.

SN 00219347

LA English

SF research-article; Copyright (C) 2007 Sage Publications, Inc.

LK http://www.jstor.org/stable/40034322

DS JSTOR

OL Unknown(0)

RT Journal Article

SR Print(0)

ID 2755 
A1 Subasinghe,Chamila

T1 Spatial confrontations: Abandonment of self-labor in transitional sheltering after a natural disaster

JF International Journal of Disaster Risk Reduction

YR 2013

FD 12

VO 6

IS 0

SP 78

OP 86

K1 Spatial confrontations

K1 Sustainable post-disaster recovery

K1 Self-labor

K1 Transitional shelters

SN 2212-4209

DO http://dx.doi.org/10.1016/j.ijdrr.2013.09.005

DS ScienceDirect

UL http://www.sciencedirect.com/science/article/pii/S2212420913000472

OL Unknown(0)

RT Journal Article

SR Print(0)

ID 451

A1 Sudmeier-Rieux,Karen

A1 Jaquet,Stephanie

A1 Derron,Marc-Henri

A1 Jaboyedoff,Michel

A1 Devkota,Sanjaya

T1 A case study of coping strategies and landslides in two villages of Central-Eastern Nepal JF Applied Geography

JO Appl.Geogr.

YR 2012

FD 3

VO 32

IS 2

SP 680

OP 690

K1 Landslide risk management

K1 Nepal

K1 Coping strategies

K1 Risk perceptions

K1 Interdisciplinary research

$\mathrm{K} 1$ Locally adapted landslide mitigation

SN 0143-6228

DO http://dx.doi.org/10.1016/j.apgeog.2011.07.005

DS ScienceDirect

UL http://www.sciencedirect.com/science/article/pii/S0143622811001408

OL Unknown(0)

RT Journal Article

SR Print(0)

ID 354

A1 Sugimoto,Megumi

A1 lemura,Hirokazu 
A1 Shaw,Rajib

T1 Tsunami height poles and disaster awareness: Memory, education and awareness of

disaster on the reconstruction for resilient city in Banda Aceh, Indonesia

JF Disaster Prevention \& Management

YR 2010

FD 11/09

VO 19

IS 5

SP 527

OP 540

K1 TSUNAMIS

K1 DISASTERS

K1 MANAGEMENT

K1 AWARENESS

K1 LITERATURE reviews

K1 SCHOOL boards

K1 DAMAGES (Law)

K1 BANDA Aceh (Indonesia)

K1 INDONESIA

K1 INDIAN Ocean

AB Purpose - This paper seeks to demonstrate a unique project with tsunami height poles and disaster education to maintain disaster awareness for several decades in the area where the Indian Ocean tsunami caused significant damage in 2004. Design/methodology/approach - A case study approach is utilized combined with field observation, participatory observation and a general literature review of relevant studies and secondary sources. Findings - The major finding is that the unique device of 85 tsunami height poles was brought from the outside to Banda Aceh city so that people may remember the impact of the tsunami over a longer period of time when awareness is likely to reduce. As local people gradually understood the significance of the poles, the number of local cooperators increased and the project"s impact improved significantly. Research limitations/implications - The long-term impact of the disaster resilience is yet to be verified in Banda Aceh city. The field research results of the project"s process and impact immediately connected with grassroots practice with people to maintain disaster awareness and resilence for the city. The practice to which the Hyogo Framework for Action gives priority connects with building understanding of tsunami risk and disaster awareness with local knowledge, assimilated by preserving disaster records and visualizing disaster. Practical implications - The paper describes a field-based project in Banda Aceh city and the suburb, Indonesia, which was implemented in cooperation with local communities, local non-government organizations, local school boards and specialists from Kyoto University, Japan. Thus, the study findings are directly related to its practical implications. Originality/value - The paper highlights how the device of 85 tsunami height poles which were built in order to visualize disaster and maintain disaster awareness under the concept, blended an expert"s unique idea with old Japanese knowledge in Banda Aceh city by the local community in Indonesia in June 2007. The paper shows that local ideas maintain living knowledge and lessons with sustainable development in the local place after the project had finished and recommendations can apply to the other tsunami affected areas. ABSTRACT FROM AUTHOR]; Copyright of Disaster Prevention \& Management is the property of Emerald Group Publishing Limited and its content may not be copied or emailed to multiple sites or posted to a listserv without the copyright holder's express written permission. However, users may print, download, or email articles for individual use. This abstract may be abridged. No warranty is given about the accuracy of the copy. Users should refer to the original published version of the material for the full abstract. (Copyright applies to all Abstracts.)

NO M3: Article

SN 09653562

AN 55372181 
LK http://library.smu.ca:2048/login?http://search.ebscohost.com/login.aspx?

direct $=$ true $\& \mathrm{db}=a p h \& A N=55372181 \&$ site=ehost-live

DS EBSCO

OL Unknown(0)

RT Journal Article

SR Print(0)

ID 629

A1 Sulagna,Swati

A1 Poyyamoli,G.

T1 Between vulnerability and adaptations: A preliminary study on natural hazards, coastline change and environmental migration in Satabhaya gram Panchayat, Orissa, India

JF International Journal of Earth Sciences and Engineering

YR 2011

VO 4

IS 5

SP 882

K1 agriculture

K1 coastal morphology

$\mathrm{K} 1$ disaster management

K1 environmental change

K1 flood

K1 GIS

K1 natural hazard

$\mathrm{K} 1$ tropical cyclone

K1 vulnerability

$A B$ Natural hazards are one of the major drivers of change around the globe. In this study we use a case study from Satabhaya gram Panchayat, Orissa, on the East coast of India to illustrate linkages between the natural hazards, loss of livelihood and environmental migration. The study area has been frequented by tropical cyclones and resultant floods. This study specifically aims to analyze last fifty years of data of occurrence of natural hazards and their subsequent impacts on the livelihoods followed by adaptation undertaken. We use geographical information system tools to detect the coastline change which has been one the major environmental change drivers. Both participatory and social survey methods were used to document the impact and the adaptations by the community. The study found that in the past, the community was exposed to a series of natural hazards which have reduced the number of villages from 7 villages to 4 in the last 40 years. Agriculture being the dominant livelihood has come to a standstill owing to constant exposure to natural disasters. $90 \%$ of households reported of migration across the country as a major source of extra income. We suggest that sustainable livelihood strategies combined with disaster risk reduction can help in mainstreaming the community into the development process. \&copy; 2011 CAFET-INNOVA TECHNICAL SOCIETY.

PP 1-18-36, Plot No A-41,F1, Vamshi Apartments,, Narayanapuram, MES Colony, Alwal, Secunderabad, 500015, India

SN 09745904

LA English

DB Compilation and indexing terms, Copyright 2013 Elsevier Inc.; GEOBASE

OL Unknown(0)

RT Journal Article

SR Print(0)

ID 530

A1 Sun, Yehong

A1 Zhou,Hongjian 
A1 Wang,Jing'ai

A1 Yuan, Yi

T1 Farmers' response to agricultural drought in paddy field of southern China: A case study of temporal dimensions of resilience

JF Natural Hazards

JO Nat.Hazards

YR 2012

VO 60

IS 3

SP 865

K1 agriculture

K1 conceptual framework

K1 drought

K1 farmers attitude

$\mathrm{K} 1$ irrigation

K1 numerical model

K1 paddy field

AB Seasonal water scarcity in southern China has been an issue of concern for many years. The increased frequency of low precipitation in the growing season of rice created a flurry of discussions in the academic and policy arenas. These events severely disrupted the supply of irrigation water for agriculture in paddy field areas and posed a substantial threat to farmers' livelihoods. Within a broader context of accessing farmers' resilience to agricultural drought, this paper focuses on the response mechanisms and adaptive strategies adopted by farming households in three types of areas (Plain, Hill, Mountain) in Dingcheng, Hunan Province. With the increasing drought frequency and the pressure from the demand for livelihood improvement, farmers' response mechanisms have evolved, expanding from short-term adjustments to long-term adaptations, and switching focus from securing reliable water sources to improving irrigation efficiency and diversifying both on- and off- farm productions. The three types of geographic units have different resilience profiles and have developed diverse patterns of adaptive processes that update the conceptual model of Disaster Resilience of "Loss-Response" of Location. It presents a temporal dimension to the study of resilience, which is largely missing from the current literature and provides insights into how to enhance farmers' response capacities in the face of agricultural drought in southern China.

\&copy; 2011 Springer Science+Business Media B.V.

PP Van Godewijckstraat 30, Dordrecht, $3311 \mathrm{GZ}$, Netherlands

SN 0921030X

LA English

LK http://dx.doi.org/10.1007/s11069-011-9873-x

DB Compilation and indexing terms, Copyright 2013 Elsevier Inc.; GEOBASE

OL Unknown(0)

RT Journal Article

SR Print(0)

ID 2607

A1 Tanaka,Takahiro

A1 Abramson,Daniel Benjamin

A1 Yamazaki,Yoshito

T1 Using GIS in community design charrettes: Lessons from a Japan-U.S. collaboration in earthquake recovery and mitigation planning for Kobe

JF Habitat International

YR 2009

FD 10

VO 33

IS 4 
SP 310

OP 318

K1 GIS

K1 Charrette

K1 Participation

K1 Disaster recovery

K1 Cross-cultural collaboration

SN 0197-3975

DO http://dx.doi.org/10.1016/j.habitatint.2008.08.006

DS ScienceDirect

UL http://www.sciencedirect.com/science/article/pii/S0197397508000465

OL Unknown(0)

RT Journal Article

SR Print(0)

ID 2258

A1 Tapsell,S. M.

A1 Penning-Rowsell,E. C.

A1 Tunstall,S. M.

A1 Wilson,T. L.

T1 Vulnerability to Flooding: Health and Social Dimensions

JF Philosophical Transactions: Mathematical, Physical and Engineering Sciences

YR 2002

FD Jul. 15

VO 360

IS 1796, Flood Risk in a Changing Climate

SP 1511

OP 1525

$A B$ This paper presents research results on the impacts that floods can have on the people affected, thus complementing the existing data on the monetary losses liable to occur in flood events. Both datasets should be used when deciding on investment in flood defence measures. We report on research on the vulnerability of flood-affected communities to adverse health effects, and the development of an index of community vulnerability based on extensive focus-group research and secondary-source census data.

PB The Royal Society

SN 1364503X

LA English

SF research-article; Copyright (C 2002 The Royal Society

LK http://www.jstor.org/stable/3066455

DS JSTOR

OL Unknown(0)

RT Journal Article

SR Print(0)

ID 890

A1 Tobin,Graham A.

A1 Whiteford,Linda M.

T1 Community Resilience and Volcano Hazard: The Eruption of Tungurahua and Evacuation of the Faldas in Ecuador

JF Disasters

JO Disasters

YR 2002

FD 03

VO 26 


\section{IS 1}

SP 28

K1 VOLCANIC hazard analysis

K1 CIVILIAN evacuation

K1 RESILIENCE (Personality trait)

K1 ECUADOR

AB Official response to explosive volcano hazards usually involves evacuation of local inhabitants to safe shelters. Enforcement is often difficult and problems can be exacerbated when major eruptions do not ensue. Families are deprived of livelihoods and pressure to return to hazardous areas builds. Concomitantly, prevailing socioeconomic and political conditions limit activities and can influence vulnerability. This paper addresses these issues, examining an ongoing volcano hazard (Tungurahua) in Ecuador where contextual realities significantly constrain responses. Fieldwork involved interviewing government officials, selecting focus groups and conducting surveys of evacuees in four locations: a temporary shelter, a permanent resettlement, with returnees and with a control group. Differences in perceptions of risk and health conditions, and in the potential for economic recovery were found among groups with different evacuation experiences. The long-term goal is to develop a model of community resilience in long-term stress environments. ABSTRACT FROM AUTHOR]; Copyright of Disasters is the property of Wiley-Blackwell and its content may not be copied or emailed to multiple sites or posted to a listserv without the copyright holder's express written permission. However, users may print, download, or email articles for individual use. This abstract may be abridged. No warranty is given about the accuracy of the copy. Users should refer to the original published version of the material for the full abstract. (Copyright applies to all

Abstracts.)

NO M3: Article

PB Wiley-Blackwell

SN 03613666

AN 6226644

LK http://library.smu.ca:2048/login?http://search.ebscohost.com/login.aspx?

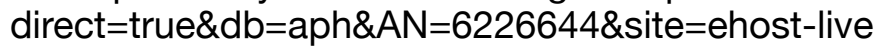

DS EBSCO

OL Unknown(0)

RT Journal Article

SR Print(0)

ID 1555

A1 Tougiani,Abasse

A1 Guero,Chaibou

A1 Rinaudo,Tony

T1 Community mobilisation for improved livelihoods through tree crop management in Niger JF GeoJournal

JO GeoJournal

YR 2009

FD 10

VO 74

IS 5

SP 377

OP 389

K1 CROP management

K1 NATURAL resources -- Management

K1 DESERTIFICATION

K1 REFORESTATION

K1 AGROFORESTRY

K1 MOBILIZATION (Social action) 
K1 NIGER

K1 Community based natural resource management

K1 Participatory approaches

K1 Poverty alleviation

K1 Revegetation

K1 Sahel

$A B$ Effective natural resource management requires interrelated technical practices and social arrangements that are appropriate to a region's biophysical characteristics and that address protection and sustainable management of resources. This is illustrated from our experience in the Republic of Niger, West Africa. In 1980 barren plains, infertile soils, drought, dust storms, severe fodder shortages, and agricultural pest outbreaks were normal occurrences in Niger's rural regions. In general, despite large investments of time and funding, conventional reforestation efforts had little impact. However by 2008 over five million hectares of once barren land had been transformed through wide adoption of an agroforestry method known as 'Farmer Managed Natural Regeneration' (FMNR), introduced in 1983. In the Aguie Department, the practice of FMNR was formalized through the Desert Community Initiative (DCI), addressing interrelated technical and social issues in resource management. New governance structures, which include marginalized groups, implement monitoring and enforcement systems enabling communities to manage land and regenerating trees. These, together with technical solutions that build on local knowledge and skills and use previously undervalued indigenous tree species, have generated a sustainable fuel-wood market for the first time. Increased linkage and compatibility between institutions at local and national levels and strengthened social capital have been crucial to these impacts. Food security and community resilience to drought have been markedly enhanced and local incomes have increased. The experience provides important lessons for approaches to addressing environmental degradation and poverty in other semi arid areas and facilitating the spread and adoption of new agroforestry systems. ABSTRACT FROM AUTHOR]; Copyright of GeoJournal is the property of Springer Science \& Business Media B.V. and its content may not be copied or emailed to multiple sites or posted to a listserv without the copyright holder's express written permission. However, users may print, download, or email articles for individual use. This abstract may be abridged. No warranty is given about the accuracy of the copy. Users should refer to the original published version of the material for the full abstract. (Copyright applies to all Abstracts.)

NO M3: Article

SN 03432521

AN 44311747

LK http://library.smu.ca:2048/login?http://search.ebscohost.com/login.aspx?

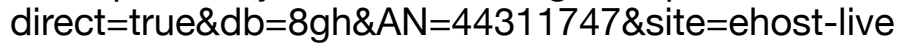

DO 10.1007/s10708-008-9228-7

DS EBSCO

OL Unknown(0)

RT Journal Article

SR Print(0)

ID 1036

A1 Tremblay,Martin

A1 Furgal,Christopher

A1 Larrivée, Caroline

A1 Annanack, Tuumasi

A1 Tookalook,Peter

A1 Qiisik,Markusi

A1 Angiyou,Eli

A1 Swappie,Noah

A1 Savard,Jean-Pierre

A1 Barrett,Michael 
T1 Climate Change in Northern Quebec: Adaptation Strategies from Community-Based Research

JF Arctic

JO Arctic

YR 2008

FD 12/02

VO 61

SP 27

OP 34

K1 CLIMATIC changes -- Effect of human beings on

K1 CLIMATOLOGY

K1 BIODIVERSITY -- Climatic factors

K1 ADAPTATION (Biology)

K1 TEMPERATURE

K1 ENVIRONMENTAL aspects

K1 JOINT ventures

K1 COASTS

K1 ARCTIC regions

K1 NORD-du-Quebec (Quebec)

$\mathrm{K} 1$ adaptation

$\mathrm{K} 1$ climate change

$\mathrm{K} 1$ ice monitoring

$\mathrm{K} 1$ integrated community-based monitoring

K1 northern Quebec

K1 scientific knowledge

$\mathrm{K} 1$ semi-structured interviews

$\mathrm{K} 1$ traditional knowledge

$\mathrm{K} 1$ changement climatique

$\mathrm{K} 1$ entrevues semi-structurées

K1 Québec nordique

K1 savoir scientifique

K1 savoir traditionnel

$\mathrm{K} 1$ suivi communautaire intégré

K1 surveillance de glace

AB Arctic communities are recently reporting warmer and shorter winters, which have implications for the ice season and, consequently, on the access to local territories and resources by members of these communities. These climatic shifts are resulting in increased risks for travel during the winter season associated with less stable and thinner ice. An integrated communitybased monitoring (ICBM) program was developed in Nunavik to generate adaptation tools to support safe access to land and resources and to enhance local adaptive capacity through participation in community-based monitoring activities. The Nunavik ICBM approach brings together partners (northern communities, Canadian universities, and various organizations) that have different perspectives on the issues surrounding land and resources in Nunavik. The ICBM project also brings together traditional knowledge and scientific knowledge, linking data collected through semi-structured interviews, local ethnocartographic interviews, and ice-monitoring activities with data gathered at weather stations. The partnership-based Nunavik ICBM program dealing with territory and resource access is an example of communities and scientists working together to improve our understanding of climate change impacts in the North, their importance for aboriginal people, and the ways in which an integrated, cooperative research process can develop local adaptive capacity. (English) ABSTRACT FROM AUTHOR]; Les communautés arctiques rapportent depuis quelques années des hivers plus chauds et plus courts qui ont des implications sur la saison de glace et par conséquent sur l'accès au territoire et aux ressources locales par les membres de ces communautés. Ces conditions climatiques ont comme conséquence d'augmenter les 
risques lors des voyages hivernaux en raison de glaces instables et plus minces. Un programme intégré de surveillance des glaces (PISG) a été développé au Nunavik pour produire des outils d'adaptation visant à soutenir l'accès sécuritaire au territoire et aux ressources et pour augmenter la capacité d'adaptation locale par la participation communautaire aux activités de surveillance. L'approche du PISG rassemble plusieurs partenaires (les communautés nordiques, universités canadiennes et différents organismes) qui s'intéressent particulièrement aux questions d'accès au territoire et aux ressources au Nunavik et y apportent des perspectives variées. Le projet du PISG intègre le savoir traditionnel et le savoir scientifique utilisant plusieurs sources de données (provenant des entrevues semistructurées, des entrevues ethno-cartographiques locales, de la surveillance de glace et des données météorologiques). Le PISG est un exemple de partenariat entre les communautés nordiques et les scientifiques qui permet de mieux comprendre les impacts des changements climatiques en cours dans le nord, leur importance sur les peuples autochtones et la façon dont la capacité d'adaptation locale peut être développée par une recherche intégrée et coopérative. (French) ABSTRACT FROM AUTHOR]; Copyright of Arctic is the property of Arctic Institute of North America and its content may not be copied or emailed to multiple sites or posted to a listserv without the copyright holder's express written permission. However, users may print, download, or email articles for individual use. This abstract may be abridged. No warranty is given about the accuracy of the copy. Users should refer to the original published version of the material for the full abstract. (Copyright applies to all Abstracts.)

NO M3: Article

PB Arctic Institute of North America

SN 00040843

AN 35849358

LK http://library.smu.ca:2048/login?http://search.ebscohost.com/login.aspx?

direct=true\&db=aph\&AN=35849358\&site=ehost-live

DS EBSCO

OL Unknown(0)

RT Journal Article

SR Print(0)

ID 499

A1 Tripathi,Raghav

A1 Sengupta,Sidharth Krishnan

A1 Patra,Adarsh

A1 Chang,Heejun

A1 Jung,Il Won

T1 Climate change, urban development, and community perception ofanextreme flood: A case study of Vernonia, Oregon, USA

JF Applied Geography

JO Appl.Geogr.

YR 2014

VO 46

SP 137

K1 climate change

$\mathrm{K} 1$ community response

K1 extreme event

K1 flooding

$\mathrm{K} 1$ floodplain

K1 GIS

K1 hydrological modeling

K1 parameterization

$\mathrm{K} 1$ peak flow

K1 perception 
K1 urban development

$A B$ Extreme precipitation events and land development on floodplains have been an increasing concern for many regions throughout the world as they increase flood risks. Using the 2007 Vernonia flood in Oregon as a case, this research examined potential changes in future flood risks under the combined climate change and urban development scenarios. Research procedures included hydraulic modeling, social analysis, and scenario analysis. Physical modeling involved creating a model for the 2007 flood, analyzing the results using Hydrologic Engineering Center - Hydrologic Modeling System (HEC-HMS), predicting variation in watershed parameters, and creating accessible maps for the public. Social questionnaires were distributed throughout Vernonia, and the results were analyzed. Our results indicate that increasing urbanization and impervious surface resulted in a major increase in the severity of flooding, exacerbating flood damage by longer inundation time and higher peak flow. The social survey revealed key discrepancies between floodplain residents and non-floodplain residents. The communal strain on the flood victims is independent of whether they lived in the floodplain or not, while floodplain residents perceived higher economic strain, family strain, and physical damage than non-floodplain residents. The information obtained from residents' response to extreme floods, along with the successful reevaluation of flood modeling at a finer scale, buttress the applicability of our procedure for flood inundation studies to other areas. Such methodologies will enhance our ability to predict and mitigate the damaging effect of floods in a changing climate. \&copy; 2013 Elsevier Ltd.

PP Langford Lane, Kidlington, Oxford, OX5 1GB, United Kingdom

SN 01436228

LA English

LK http://dx.doi.org/10.1016/j.apgeog.2013.11.007

DB Compilation and indexing terms, Copyright 2013 Elsevier Inc.; GEOBASE

OL Unknown(0)

RT Journal Article

SR Print(0)

ID 356

A1 UEDA,KYOKO

A1 TORIGOE,HIROYUKI

T1 Why do Victims of the Tsunami Return to the Coast?

JF International Journal of Japanese Sociology

YR 2012

FD 03

VO 21

IS 1

SP 21

OP 29

K1 TSUNAMIS

K1 FISHING villages

K1 VULNERABILITY model of recovery

K1 ECOLOGICAL resilience

K1 SENDAI Earthquake, Japan, 2011

K1 TSUNAMI damage

K1 JAPAN

$\mathrm{K} 1$ fishing village

$\mathrm{K} 1$ resilience

K1 tsunami

$A B$ The purpose of this paper is to clarify why people continuously live in places where a specific natural disaster comes with apparent frequency. Even after a natural disaster of tremendous scale occurs, some victims attempt to remain or later return 'home' while inviting the risk of experiencing further catastrophe. Why do people opt to continuously live where they 
are prone to natural disasters instead of living at a distance from the coastline? Especially for those who have just experienced the tsunami; what motivates them to make the decision to go back to the coast? As the case study of a community in a fishing village indicates, people know that life near the coast is inevitably entwined with both the severity and fertility of the sea. In other words, what people know is that they cannot have one without the other. Both sides of the sea have conditioned the life of people and that is what they have adapted to. Because of their closeness to the sea, the fertility they have enjoyed and the vulnerability as a coastal community are inseparable for them. When the tsunami struck, they did not know how to save all members of the community, their homes, nor their ships. Whereas, they did know how they should adapt to the inherent instability of their coastal community and how they should revive the community. This process would unfold only after having an understanding of the way in which they needed to adapt to their local bay. As a coastal community they were ready to accept their vulnerability, even immediately after the destruction of the tsunami, as it was the condition in which to enjoy the fertility of the sea as their ancestors had done throughout history. ABSTRACT FROM AUTHOR]; Copyright of International Journal of Japanese Sociology is the property of Wiley-Blackwell and its content may not be copied or emailed to multiple sites or posted to a listserv without the copyright holder's express written permission.

However, users may print, download, or email articles for individual use. This abstract may be abridged. No warranty is given about the accuracy of the copy. Users should refer to the original published version of the material for the full abstract. (Copyright applies to all

Abstracts.)

NO M3: Article

PB Wiley-Blackwell

SN 09187545

AN 74463808

LK C: UUsers\s9130263\Documents\Cases\Ueda_\&_Torigo_2012.pdf

DO 10.1111/j.1475-6781.2012.01159.x

DS EBSCO

OL Unknown(0)

RT Journal Article

SR Print(0)

ID 1657

A1 van Heerden,Ivor LI

T1 The Failure of the New Orleans Levee System Following Hurricane Katrina and the Pathway Forward

JF Public administration review

JO Public Adm.Rev.

YR 2007

FD 12/02

VO 67

SP 24

OP 35

K1 HURRICANE protection

K1 FLOOD control

K1 ENVIRONMENTAL protection

K1 ENVIRONMENTAL engineering

K1 ENVIRONMENTAL disasters

K1 REGIONAL planning

AB Hurricane Katrina made landfall as a fast-moving Category 3 storm. Thereafter, 85 percent of Greater New Orleans was flooded, 1,500 lives were lost, and approximately 100,000 were left homeless. New Orleans' hurricane protection system failed catastrophically, leaving miles of levees without protection from waves. With global warming accelerating, smarter planning is needed for many coastal cities and communities. Surge defenses that make full use of natural 
and man-made components need to be augmented with sustainable development and retreat from low-lying coastal regions. Coastal restoration is the key to the future habitation of southeast Louisiana, together with an east-west levee/surge protection system across the midcoast. This latter system must be complimented and protected by aggressive coastal wetland and barrier island restoration. ABSTRACT FROM AUTHOR]; Copyright of Public Administration Review is the property of Wiley-Blackwell and its content may not be copied or emailed to multiple sites or posted to a listserv without the copyright holder's express written permission. However, users may print, download, or email articles for individual use. This abstract may be abridged. No warranty is given about the accuracy of the copy. Users should refer to the original published version of the material for the full abstract. (Copyright applies to all

Abstracts.)

NO M3: Article

SN 00333352

AN 27727800

LK http://library.smu.ca:2048/login?http://search.ebscohost.com/login.aspx?

direct $=$ true $\& \mathrm{db}=8 \mathrm{gh} \& \mathrm{AN}=27727800 \&$ site $=$ ehost-live

DO 10.1111/j.1540-6210.2007.00810.x

DS EBSCO

OL Unknown(0)

RT Journal Article

SR Print(0)

ID 244

A1 Vermaak, Jaco

A1 van Niekerk, Dewald

T1 Disaster risk reduction initiatives in South Africa

JF Development Southern Africa

YR 2004

VO 21

IS 3

SP 555

K1 coping strategy

$\mathrm{K} 1$ disaster management

$\mathrm{K} 1$ flood control

$\mathrm{K} 1$ traditional knowledge

K1 vulnerability

$A B$ The field of disaster management in South Africa has developed dramatically over the past seven years. The paradigm shift from civil protection to disaster risk management brought with it the realisation that the management of disaster risk is paramount to reducing successfully the vulnerability of these communities most at risk. The resilience and coping mechanisms of communities affected by disasters have demonstrated the importance of local and traditional knowledge in the reduction of risk and the effects of hazards. This article aims to explore various initiatives for disaster risk reduction in South Africa undertaken by government departments and non-governmental organisations from 1994 to 2003. It describes the various methods and systems employed to reduce risk and vulnerability. A case study of the February 2000 floods in the Limpopo province of South Africa provides insight into local coping mechanisms and indigenous methods of risk reduction. \&copy; 2004 Development Bank of Southern Africa.

SN 0376835X

LA English

LK http://dx.doi.org/10.1080/0376835042000265487

DB Compilation and indexing terms, Copyright 2013 Elsevier Inc.; GEOBASE

OL Unknown(0) 
RT Journal Article

SR Print(0)

ID 2518

A1 Verschuur, M.

A1 Spinhoven,P.

A1 Emmerik,A. van

A1 Rosendaal,F.

T1 Making a bad thing worse: Effects of communication of results of an epidemiological study after an aviation disaster

JF Social science \& medicine

JO Soc.Sci.Med.

YR 2007

FD 10

VO 65

IS 7

SP 1430

OP 1441

K1 Disaster

K1 Psychopathology

K1 Somatic complaints

K1 Reassurance

K1 Risk communication

K1 The Netherlands

SN 0277-9536

DO http://dx.doi.org/10.1016/j.socscimed.2007.05.014

DS ScienceDirect

UL http://www.sciencedirect.com/science/article/pii/S0277953607002766

OL Unknown(0)

RT Journal Article

SR Print(0)

ID 882

A1 Wang,Lih-Rong

A1 Chen,Steven

A1 Chen,Joseph

T1 Community Resilience after Disaster in Taiwan: A Case Study of Jialan Village with the Strengths Perspective

JF Journal of Social Work in Disability \& Rehabilitation

YR 2013

FD Jan

VO 12

IS 1

SP 84

OP 101

K1 ADAPTABILITY (Psychology)

K1 COMMUNITIES

K1 CONTENT analysis (Communication)

K1 FOCUS groups

K1 INTERVIEWING

K1 LEARNING strategies

K1 NATURAL disasters

K1 QUESTIONNAIRES

K1 RESILIENCE (Personality trait)

K1 HEALTH self-care 
K1 TAIWAN

K1 community resilience

K1 community work

K1 coordination

$\mathrm{K} 1$ disaster management

$\mathrm{K} 1$ protective factors

K1 self-help

K1 social work intervention

$\mathrm{K} 1$ strengths perspective

$A B$ This article examines community resilience in disaster recovery in Jialan Village, where many families lost their homes when Typhoon Morakot struck Taiwan in 2008. In-depth interviews were conducted with policymakers, social workers, resource coordinators, and leaders of the local aboriginal community. The main findings were (a) the village's recovery was due to the effective use and coordination of community resources; (b) partnership building between the public and private sectors was crucial in the community's recovery; and (c) the recovery was enhanced by values such as a strong sense of mutual help, good physical health, positive attitudes, and autonomy. ABSTRACT FROM AUTHOR]; Copyright of Journal of Social Work in Disability \& Rehabilitation is the property of Taylor \& Francis Ltd and its content may not be copied or emailed to multiple sites or posted to a listserv without the copyright holder's express written permission. However, users may print, download, or email articles for individual use. This abstract may be abridged. No warranty is given about the accuracy of the copy.

Users should refer to the original published version of the material for the full abstract.

(Copyright applies to all Abstracts.)

NO M3: Article

SN 1536710X

AN 87666670

LK http://library.smu.ca:2048/login?http://search.ebscohost.com/login.aspx?

direct $=$ true $\& \mathrm{db}=a p h \& A N=87666670 \&$ site $=$ ehost-live

DO 10.1080/1536710X.2013.784551

DS EBSCO

OL Unknown(0)

RT Journal Article

SR Print(0)

ID 2612

A1 Weber,Lynn

A1 Hilfinger Messias, DeAnne K.

T1 Mississippi front-line recovery work after Hurricane Katrina: An analysis of the intersections of gender, race, and class in advocacy, power relations, and health

JF Social science \& medicine

JO Soc.Sci.Med.

YR 2012

FD 6

VO 74

IS 11

SP 1833

OP 1841

K1 USA

K1 Intersectionality

K1 Hurricane Katrina

K1 Disaster recovery

K1 Health disparities

K1 Burnout

K1 Advocacy work 
K1 Gender

K1 Race

K1 Class

K1 Social justice

T2 Gender and health: Relational, intersectional, and biosocial approaches

SN 0277-9536

DO http://dx.doi.org/10.1016/j.socscimed.2011.08.034

DS ScienceDirect

UL http://www.sciencedirect.com/science/article/pii/S0277953611005521

OL Unknown(0)

RT Journal Article

SR Print(0)

ID 517

A1 Wilson,Crispen

A1 Linkie,Matthew

T1 The panglima laot of Aceh: A case study in large-scale community-based marine management after the 2004 Indian Ocean tsunami

JF Oryx

JO Oryx

YR 2012

VO 46

IS 4

SP 495

$\mathrm{K} 1$ community resource management

K1 coral

$\mathrm{K} 1$ coral reef

$\mathrm{K} 1$ data set

$\mathrm{K} 1$ fishery management

$\mathrm{K} 1$ fishing community

K1 governance approach

K1 GPS

K1 Indian Ocean tsunami 2004

$\mathrm{K} 1$ management practice

K1 map

K1 seamount

$\mathrm{K} 1$ traditional knowledge

$\mathrm{K} 1$ tsunami

AB Abstract Despite dating back over 400 years the relevance of traditional fisheries management in Aceh, Indonesia, still remains high. Aceh was, however, greatly affected by the December 2004 Indian Ocean tsunami that claimed an estimated 167,000 lives, including 14,000 fishermen and 59 of the 193 traditional marine leaders (Panglima Laot). This tragic loss of life was accompanied by a substantial loss of local knowledge, such as the locations of hazardous fishing grounds. In this study we describe an innovative project that sought to rebuild a post-tsunami fisheries sector by re-engaging and empowering the Panglima Laot. During April-June 2008 GPS (global positioning system) sounding devices were installed on 53 local fishing boats and hazardous fishing areas mapped based on local knowledge, and shared amongst fishermen. During July-December 2008 nearly five million GPS data points were collected, from which detailed bathymetric maps were produced and shared between fishermen and Aceh government officials. Significant project outputs included a map of fishing areas over 20,000-km2, which included three new seamounts, one of which expanded Aceh's provincial boundary by $>-1.3$ million ha, and a Panglima Laot decree that reduced fishing in hazardous areas of high coral density by $23.3 \%$. Our findings have wide applicability. Locally, the introduction of GPS technology and sharing of traditional knowledge resulted in fishermen 
developing and implementing their own management strategies and demonstrating their ability to stay out of restricted areas. Provincially, this project provided a framework through which government agencies and academic institutions could effectively engage with local customary leaders and their fishing communities. \&copy; 2012 Fauna \& Flora International.

PP Shaftesbury Road, Cambridge, CB2 2RU, United Kingdom

SN 00306053

LA English

LK file://C:/Users/s9130263/Documents/Cases/Wilson_\&_Linkie_2012.pdf

DB Compilation and indexing terms, Copyright 2013 Elsevier Inc.; GEOBASE

OL Unknown(0)

RT Journal Article

SR Print(0)

ID 899

A1 Wilson,Geoff A.

T1 Community resilience, social memory and the post-2010 Christchurch ( New Zealand) earthquakes

JF Area

JO Area

YR 2013

FD 06

VO 45

IS 2

SP 207

OP 215

K1 CHRISTCHURCH Earthquake, N.Z., 2011

K1 RESILIENCE (Personality trait)

K1 COLLECTIVE memory

K1 EARTHQUAKES

K1 NEW Zealand

K1 adaptive capacity

K1 Christchurch earthquakes

$\mathrm{K} 1$ natural hazard

$\mathrm{K} 1$ resilience

K1 social memory

$A B$ This article explores the importance of social memory for community resilience pathways in the city of Christchurch ( New Zealand) in the wake of the post-2010 earthquakes. Specific emphasis is placed on understanding how past earthquake history in Christchurch has influenced knowledge about, and responses to, the recent series of earthquakes. Building on previous work about possible impacts of social memory on community resilience, the paper argues that Christchurch residents were ill prepared for the sudden onset of on-going earthquakes, and that the continuing threat, and associated uncertainty, posed by these tremors is gradually eroding residents' ability to cope and plan for the future. ABSTRACT FROM AUTHOR]; Copyright of Area is the property of Wiley-Blackwell and its content may not be copied or emailed to multiple sites or posted to a listserv without the copyright holder's express written permission. However, users may print, download, or email articles for individual use. This abstract may be abridged. No warranty is given about the accuracy of the copy. Users should refer to the original published version of the material for the full abstract. (Copyright applies to all Abstracts.)

NO M3: Article

SN 00040894

AN 87549879

LK http://library.smu.ca:2048/login?http://search.ebscohost.com/login.aspx?

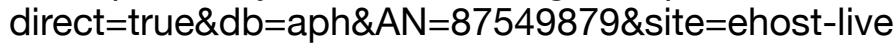


DO 10.1111/area.12012

DS EBSCO

OL Unknown(0)

RT Journal Article

SR Print(0)

ID 1829

A1 Xiao,Yu

A1 Van Zandt,Shannon

T1 Building Community Resiliency: Spatial Links between Household and Business Post-

disaster Return

JF Urban Studies

JO Urban Stud.

YR 2012

FD Nov 2012

VO 49

IS 11

SP 2523

OP 2542

K1 Housing And Urban Planning

K1 Environment Abstracts

K1 Sustainability Science Abstracts

K1 M3 1010:Issues in Sustainable Development

K1 ENA 12:Oceans \& Estuaries

AB Rapidly urbanising areas along the world's coasts are exposing greater numbers of households to more frequent and severe natural and man-made disasters. Knowledge gained from disaster situations can provide insight into larger urban forces and play a role in developing and prescribing policies that influence the creation of more resilient communities.

This article explores the interdependency of households and businesses in post-disaster return following 2008's Hurricane Ike in Galveston, Texas. Geocoded data from 980 households and 145 businesses collected in the months after the storm allow the spatial correlation of the household occupancy and business operation, controlling for damage. Findings suggest that the return of households and businesses are mutually dependent across space. The re-opening of businesses can influence nearby households' decisions to return to their homes and the return of households in the market area will increase the chances for businesses to return.

NO Source type: scholarlyjournals; Object type: Article; Object type: Feature; CSAUnique: OBdcb5a9f7-05b4-4955-b78fmfgefd101; AccNum: 16972322; DOI: 10.1177/0042098011428178; ISSN: 0042-0980; Peer Reviewed: true

PB Sage Publications, Inc

PP United States

SN 0042-0980

AN 1223273057; 16972322

LA English

LK file://C:/Users/s9130263/Documents/Cases/Xiao_\&_Van_Zandt_2011.pdf

DO http://dx.doi.org/10.1177/0042098011428178

DB GeoRef

DS ProQuest

UL http://smu.worldcat.org/openurlresolver?

genre=article\&isbn=\&issn=00420980\&title=Urban+Studies\&title=Building+Community+Resilien cy\%253A+Spatial+Links+between+Household+and+Business+Post-

disaster+Return\&volume=49\&issue=11\&date=2012\&atitle=Building+Community+Resiliency\%2 $53 \mathrm{~A}+$ Spatial+Links+between+Household+and+Business+Post-

disaster+Return\&aulast=Xiao\%252c+Yu\&spage=2523\&sid=ProQ\%253Apqdiearthsci\&pid=; http://dx.doi.org/10.1177/0042098011428178 
OL Unknown(0)

RT Journal Article

SR Print(0)

ID 2427

A1 Zahari,Rustam Khairi

A1 Ariffin,Raja Noriza Raja

T1 Community-Based Disaster Management in Kuala Lumpur

JF Procedia - Social and Behavioral Sciences

YR 2013

FD 9/20

VO 85

IS 0

SP 493

OP 501

K1 Sustainable communities

K1 community-based organisation

K1 urban hazards

K1 adaptation

T2 AcE-Bs 2013 Hanoi (ASEAN Conference on Environment-Behaviour Studies), Hanoi

Architectural University, Hanoi, Vietnam, 18-21 March 2013.

SN 1877-0428

DO http://dx.doi.org/10.1016/j.sbspro.2013.08.378

DS ScienceDirect

UL http://www.sciencedirect.com/science/article/pii/S1877042813025056

OL Unknown(0)

RT Journal Article

SR Print(0)

ID 2481

A1 Zahari,Rustam Khairi

A1 Ariffin,Raja Noriza Raja

A1 Asmawi,M. Zainora

A1 Ibrahim,Aisyah Nadhrah

T1 Impacts of the 2004 Tsunami: Preparedness of the Malaysian Coastal Communities

JF Procedia - Social and Behavioral Sciences

YR 2013

FD $12 / 3$

VO 105

IS 0

SP 569

OP 576

K1 Tsunami

$\mathrm{K} 1$ sustainable coastal communities

K1 disaster management

K1 vulnerability

T2 AicE-Bs 2013 London (Asia Pacific International Conference on Environment-Behaviour Studies), 4-6 September 2013

SN 1877-0428

DO http://dx.doi.org/10.1016/j.sbspro.2013.11.060

DS ScienceDirect

UL http://www.sciencedirect.com/science/article/pii/S1877042813044352

OL Unknown(0) 
RT Journal Article

SR Print(0)

ID 1918

A1 Zavestoski,Stephen

A1 Mignano,Frank

A1 Agnello, Kate

A1 Darroch,Francine

A1 Abrams, Katy

T1 Toxicity and Complicity: Explaining Consensual Community Response to a Chronic

Technological Disaster

JF The Sociological Quarterly

YR 2002

FD Summer

VO 43

IS 3

SP 385

OP 406

$\mathrm{AB}$ The absence of citizen mobilization following the announcement of high levels of dioxin in a New England river, and subsequent Superfund listing, is explained in light of previous research that stresses the conflict and controversy that surround community contamination. Interviews with area residents and government officials, observations of public meetings, and content analyses of newspaper articles, EPA press releases, and other official documents provide three explanations for the absence of citizen mobilization: (1) shared knowledge of the community's industrial history meant the river's contamination did not disrupt taken-for-granted assumptions about the community, (2) the "discovery" of the contamination by a government agency and its subsequent impression management served to defuse the public outrage that would otherwise lead to controversy and confrontation, and (3) elected officials, who were able to get resources to the agencies that could handle the problem, supported the decisions of the agencies rather than criticizing them or accusing them of negligence.

PB Wiley on behalf of the Midwest Sociological Society

SN 00380253

LA English

SF research-article; Copyright @ 2002 Midwest Sociological Society

LK http://www.jstor.org/stable/4121533

DS JSTOR

OL Unknown(0) 